\title{
Redefining the Vernacular in the Hybrid Architecture of Malaysia
}

\author{
A thesis \\ submitted in partial fulfilment of the requirements for the Degree of \\ Master of Architecture \\ Victoria University of Wellington \\ June 2010 \\ by \\ Stefanie Sim
}

Under the supervision of

Christine McCarthy 


\section{Abstract}

The objective of the thesis is to view the presence of vernacular architecture as a strong sub current of modern praxis in Malaysia. Vernacular architecture has played a pivotal role in shaping architecture and in defining perceptions of modernity. It is the vernacular interaction and negotiation with regional and global influences that has generated the complex and hybrid nature of Malaysian architecture.

The notion of the 'vernacular' has a negative and pejorative connotation and is commonly described as simplistic, unrefined and undeveloped. Contrary to that, the thesis reveals the complex cultural, social, intellectual and functional identities of Malaysian vernacular structures. The term 'vernacular' is constantly evolving and is not limited to the past but lives on in contemporary architecture. The thesis suggests that the presence of vernacular concepts do not dissipate as a result of hybrid interactions between different cultures but rather evolve during this creative process.

Significant events that transpire throughout the history of the country play a crucial role in shaping and altering vernacular architecture. Colonisation and migration contribute to the complex architectural identity of Malaysia as diverse cultural influences are introduced and imposed onto native traditions. Change is inevitable in a living society. However, change can be seen as either disruptive or as part of a continuum. Through critical comparisons and case studies, the thesis argues that the vernacular is continually evolving as a product of cultural regeneration. It is from the parallels drawn between the vernacular and architecture introduced by foreigners that allow for the comprehension of these new building types as well as the acceptance of alternate lifestyle. 


\section{Table of Contents}

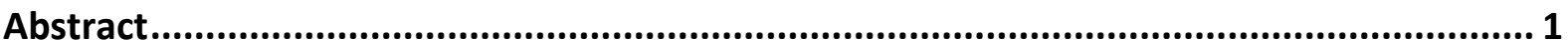

Table of Contents

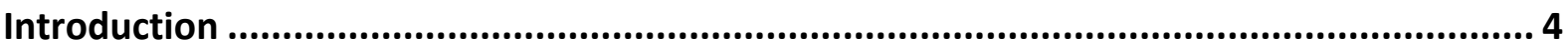

Chapter 1: Malaysian Vernacular Architecture Part I (16 ${ }^{\text {th }}$ century) ................................. 17

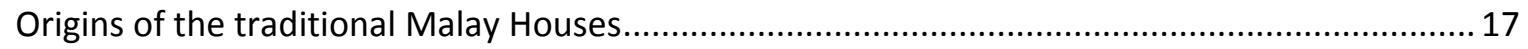

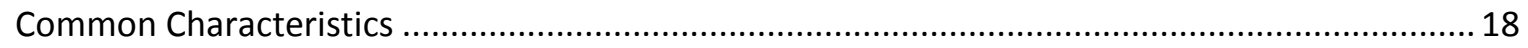

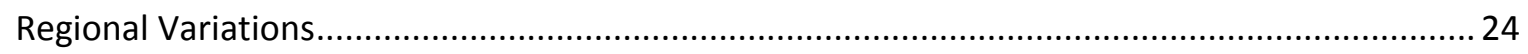

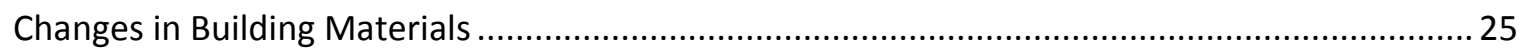

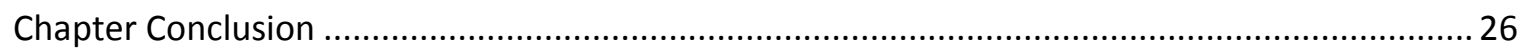

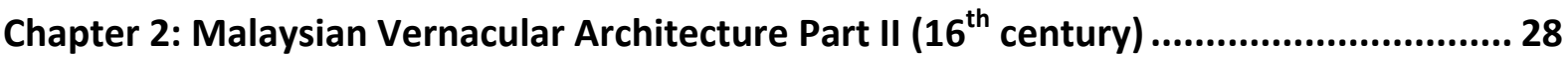

Origins of the Longhouses of the indigenous people of Sarawak …...............................................29

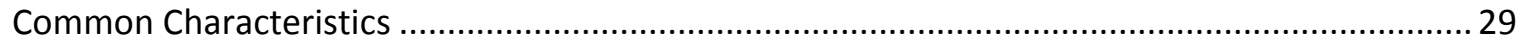

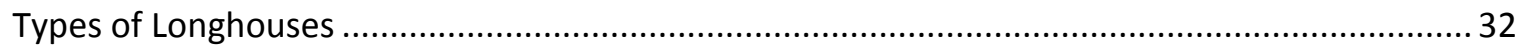

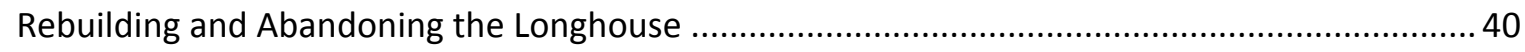

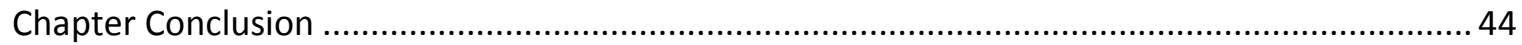

Chapter 3: Foreign Influenced Architecture Part I (1511-1957) ...................................... 46

Architecture of the Immigrants - The Chinese Community …......................................................... 46

Colonial architecture of the Portuguese, Dutch and the British ................................................... 57

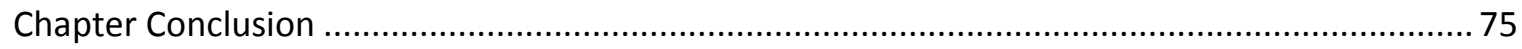

Chapter 4: Foreign Influenced Architecture Part II (1795-1957) ....................................... 78

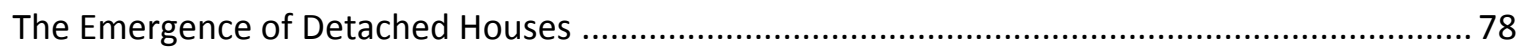

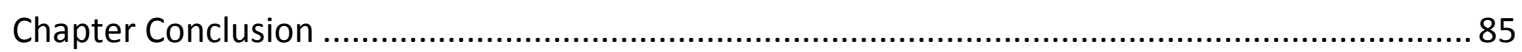


Chapter 5: Contemporary Malaysian Architecture (1957-present) .................................. 87

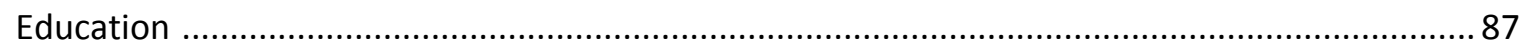

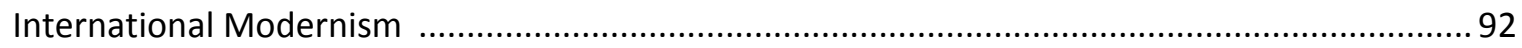

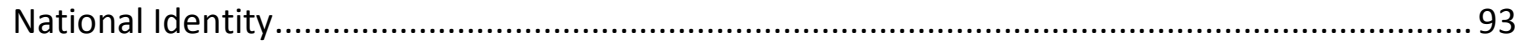

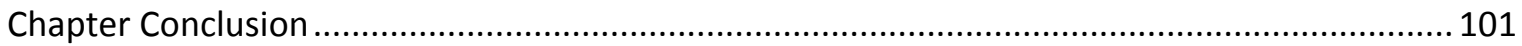

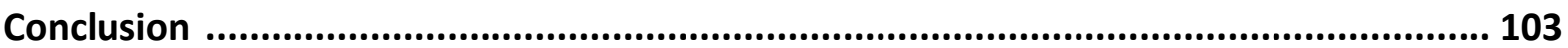

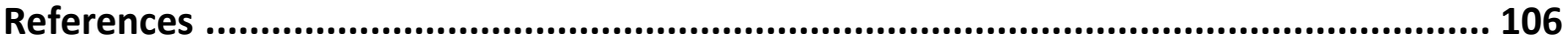

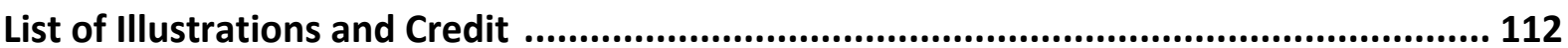

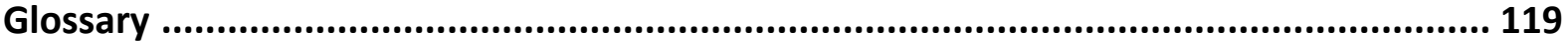




\section{Introduction}

Architecture is not always pure in form and isolated in its origin and may develop from different sources at different times. The complex nature of Malaysian architecture arises from the creative process of intercultural exchanges and localization of imported models. As so much of what is described as 'Malaysian vernacular architecture' doesn't originate from the region but is foreign and imported, the definition of 'vernacular' invites further exploration. The thesis suggests that the synthesis of old and new, as well as local and foreign, generated intercultural exchanges in architecture, and was paralleled throughout with the continual evolution of the vernacular in response to these forces of changes. The thesis supports the notion that vernacular architecture is not limited to signify the past but instead is a dynamic process of development over time by the collective actions of individuals. ${ }^{1}$ Recurrent themes which will be explored in the thesis include:

- the conventional manifestations of power and status

- social and spatial organization

- architectural strategies to achieve culturally and environmentally appropriate design solutions

Malaysia is the perfect place for this study as the country yields numerous examples of multicultural and colonial architecture. In Malaysia, architectural hybridization was not so much the exception but the norm. It is a melting pot of diverse cultures, religion and nationalities. According to a recent census conducted by the Statistics Department, Malaysia is home to approximately 27 million people. The population comprises of 50.91\% Malays, $24.46 \%$ Chinese, $11 \%$ non-Muslim indigenous people, $7.22 \%$ Indians, $7.11 \%$ others (non Malaysian citizens and citizens of a difference race). ${ }^{2}$ Under the law of Malaysia, indigenous people are categorised under the heading 'Bumiputera' which literally translates as 'son of the earth'. ${ }^{3}$ There are also many other significant cultural groups including the indigenous groups of Sabah and the Malay Peninsula, immigrant groups such as the Indian and Arab, and of neighbouring countries such as Thailand and Indonesia. Due to the limitations of the Master's thesis, this thesis is a selective rather than a comprehensive analysis of

\footnotetext{
${ }^{1}$ Heath Vernacular Architecture and Regional Design xiv

${ }^{2}$ Ismail Houses in Malaysia. Fusion of the East and the West p10

${ }^{3}$ Tettoni and Ong Sarawak Style p17

All the indigenous people are categorised as "Bumiputera" under the Malaysian law. The definition of "indigenous people" includes ethnic Malays (Muslim) as well as ethnic communities (Non-Muslim)- the main groups being the Iban, Bidayuh , Melanau and the Orang Ulu which more commonly reside in the Island of Borneo. Colonial historians used the term "Dayaks" to denote all non-Muslim indigenous people, although today the name "Iban" replaces the word "Sea Dayak: and "Bidayuh" instead of "Land Dayak". Orang Ulu means "upriver people" and covers a host of smaller ethnic tribes such as the Kayan, Kenyah, Punan, Kajang, Kejaman, Kelabit and Lun Bawang.
} 
Malaysian architecture. It does not include the architecture of all the indigenous groups and foreign influences of Malaysia as this would go beyond the physical scope of the thesis ${ }^{4}$ and it is for this pragmatic reason, rather than any other, that the thesis has focussed on the architecture of the largest cultural groups in Malaysia. This omission is unfortunate as the other cultural groups have played major roles in shaping Malaysian architecture as we know it.

Malaysia's climate is categorised as equatorial, with high temperatures, high humidity and heavy rainfall throughout the year. The temperature usually ranges between $22-32^{\circ} \mathrm{C}$ and annual rainfall exceeds $2000 \mathrm{~mm}$ a year. Malaysia has two seasons which are the wet and dry seasons. These seasons are related to the Monsoon winds. The Southwest Monsoon prevails from late May to September, and the Northeast Monsoon prevails from November to March. The houses in Malaysia are forced to take into consideration the constant hot, humid and wet climate to achieve comfortable living. Climate control strategies include adequate ventilation for cooling and reducing the effects of humidity, the application of building materials with low thermal capacity, controlling the direction of solar radiation, providing protection from rain and ensuring adequate vegetation in the surroundings to provide a cooler micro climate. ${ }^{5}$

Malaysia is located in South East Asia and comprises two distinct parts: the Malay Peninsula (West Malaysia) and Sabah, Sarawak and the Federal Territory of Labuan, which are situated on the island of Borneo (East Malaysia). The country shares international borders with Indonesia, Singapore, Brunei and Thailand.

Malaysia's geographical location made it a vital route during the spice trade. Specifically, Melaka ${ }^{6}$ is positioned at the convergence of major sea routes which meant that it was established as an important seaport for trade between the East and West at the end of the fourteenth century. Melaka came into contact with India, China, Africa and Europe, later embracing Islam, the religion spread by the Arab and Indian Muslim traders. ${ }^{7}$

\footnotetext{
${ }^{4}$ Other limitations to approach- a number of built configurations discussed in the thesis, particularly the ones pertaining to immigrant and colonial architecture, heavily depended on second hand sources and whose descriptions have only skimmed the surface. Therefore, implications of foreign influences can be further explored within other sources to determine accuracy.

${ }^{5}$ Ismail Houses in Malaysia. Fusion of the East and the West p10

${ }^{6}$ Melaka, is the alternate spelling to Malacca

${ }^{7}$ Ismail Houses in Malaysia. Fusion of the East and the West p5
} 


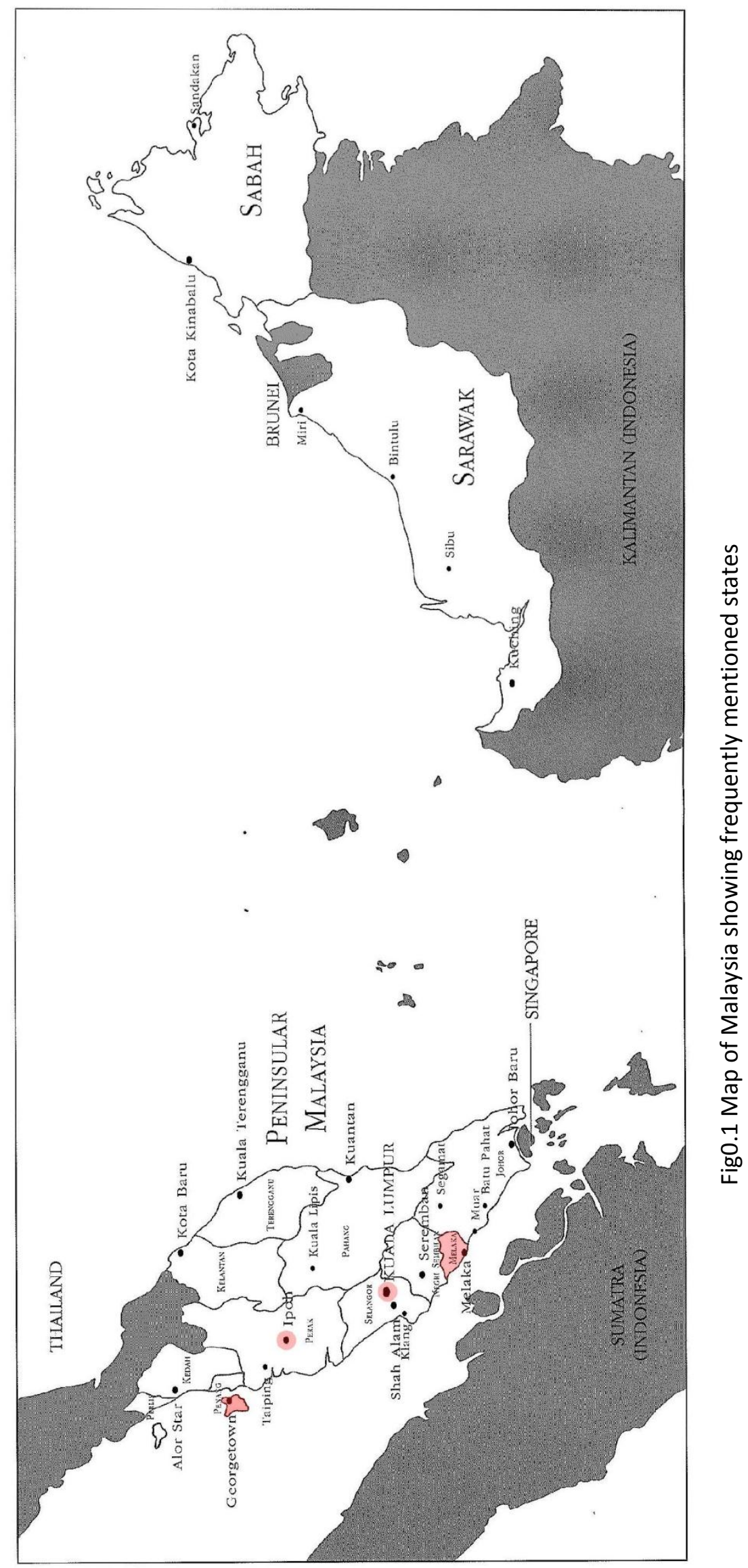


From the fifteenth century, the Chinese permanently settled in Melaka as traders and merchants, bringing their cultures and customs, leading to an architectural style described as the Straits Eclectic. ${ }^{8}$ These Chinese settlers brought about urban building types such as shophouses and townhouses. They also introduced elements such as courtyards and masonry staircases to vernacular Malay houses.

In 1511, the Portuguese, seeking to dominate this trade route, captured Melaka and controlled the city-port's economic and political affairs. During the Portuguese colonization of Melaka, the architectural style of Manueline Gothic was introduced for the first time in the East. ${ }^{9}$ Stone construction was introduced and laterite became a popular building material. The style was the last phase of Gothic architecture in Portugal and is characterized by square-shaped, barn-like structures. ${ }^{10}$ To safeguard their conquests, the Portuguese constructed a great fortress named $\mathrm{A}$. Famosa in 1512, which was on the site of the Malay fort and royal compound on the hill. The Portuguese also erected churches and other religious monuments to fulfill their intentions of spreading Roman Catholicism. Early religious buildings in Melaka included the Jesuit College of St Paul (1548) and St Paul's Church (1521). The Portuguese did not make a significant impact on local architecture. They established several residential settlements that contained houses made out of timber and roof tiles but these were isolated from the local population. ${ }^{11}$

The Dutch, who also wanted to control trade in the Peninsula, besieged Melaka over one hundred years later in 1641. This occupation left a unique architectural impression in the form of three-storey Stadthuys (town hall), brick townhouses or 'row houses', palaces, mansions and churches. These buildings exhibit Dutch architectural features such as thick masonry walls, Dutch-style gables, double-sash windows and decorative elements on the facades and window copings of shophouses.

The following century, in 1795, the British occupied the Malay Peninsula and set up the Straits Settlements of Penang, Melaka and Singapore with the aim of exploiting natural resources. ${ }^{12}$ The other Malay states remained essentially self-governing kingdoms under their local rulers with the British taking little interest in their affairs. ${ }^{13}$ This situation resulted in little development and construction of buildings. The primary aim of the colonial administration was essentially to exploit the natural resources of the land. As a method of managing the different cultures, the ethnic groups

\footnotetext{
${ }^{8}$ Yeang The Architecture of Malaysia p27

${ }^{9}$ Chen 'Architecture' The Encyclopaedia of Malaysia p8

${ }^{10}$ Chen 'Architecture' The Encyclopaedia of Malaysia p8

${ }^{11}$ Yeang The Architecture of Malaysia p28

12 Ismail Houses in Malaysia. Fusion of the East and the West p5

${ }^{13}$ Chen 'Architecture' The Encyclopaedia of Malaysia p9
} 
were segregated. The British encouraged the Chinese to work in the tin mines, the Indians to work in rubber plantations and road building, while the Malay peasantry worked on small holdings and providing rice. This "divide and rule policy" resulted in minimal inter-racial activities and culturally isolated buildings. ${ }^{14}$ Each ethnic group retained their original cultural tradition but lived in different places: the Malays in their villages, the Chinese near the tin mines, or town centers, and the Indians in their rubber plantations. ${ }^{15}$

The British administration initially resided in timber structures resembling the Malay houses but these houses gradually transformed to include elements of the Chinese and of England. ${ }^{16}$ Chinese roofing tiles replaced the thatch roof which was subsequently replaced by the design of the 'jackroof', where the roof was divided into two sections, with the higher section overlapping the lower one. ${ }^{17}$ In an attempt to enhance the houses' prestige, western elements and ornamentation were adopted. ${ }^{18}$ These included Doric columns, Greek and Roman motifs, and other elements reminiscent of the Palladian Neo-Classicism which was a prevailing trend in England from the sixteenth to the nineteenth century. ${ }^{19}$ This blend of foreign and indigenous elements produced a style known as the Anglo-Straits Eclectic Style.

Meanwhile, over in the East, Sarawak was ruled by a dynasty of White Rajahs, the Brookes, which transformed Kuching into a modern town. The British rule was briefly disrupted by the invasion of the Japanese in December 1941 during the Second World War. The Japanese military occupation was short lived and left no substantial monuments as the Japanese only built temporary shelters during their occupation of Malaya. ${ }^{20}$ The British regained power in 1945. On August 1957 the Independence of the Federation of Malaya was proclaimed with Sabah, Sarawak and Singapore integrating with the Malay Peninsula to form Malaysia later in 1963, ${ }^{21}$ however in 1965, Singapore split from Malaysia to become an independent city-state.

Malaysian architectural history, as seen above, is complex and has involved many peoples and many cultural interactions. These cultural exchanges have formed the development of Malaysian vernacular architecture.

\footnotetext{
${ }^{14}$ Choong Multiculturalism : the roots of Malaysian architecture and identity $\mathrm{p} 17$

${ }^{15}$ Choong Multiculturalism : the roots of Malaysian architecture and identity p19

${ }^{16}$ Yeang The Architecture of Malaysia p146

${ }^{17}$ Yeang The Architecture of Malaysia p146

${ }^{18}$ Yeang The Architecture of Malaysia p146

${ }^{19}$ Yeang The Architecture of Malaysia p144

${ }^{20}$ Ismail Houses in Malaysia. Fusion of the East and the West p43

${ }^{21}$ The term 'Malaya' denominated the Malay Peninusla and is usually meant to include the island of Singapore. Malaysia was formed in 1963 as a federation of the states of the Malay peninsula and the states of Sabah and Sarawak in Borneo. Singapore seceded in 1965 to become an independent republic.
} 


\section{Malaysian Vernacular Architecture}

The term 'vernacular' derives from the Latin vernaculus, meaning native, and is most widely used to denote indigenous, tribal, folk, peasant and traditional architecture. ${ }^{22}$ According to Chen, vernacular house forms evolved according to different cultural settings and are the results of long-term modification, adaptations, shared experiences and innovations. ${ }^{23}$ The terms 'vernacular', 'traditional', 'indigenous', and 'regional' are often used interchangeably.

Rudofsky defines the vernacular as 'nearly immutable and without the need for improvements since it serves its purpose to perfection' ${ }^{24}$ The thesis, however, agrees with Rapoport's perspective of the vernacular as a process, of how it comes to be, or as a product - a resulting environment having certain characteristics. He states that vernacular design is achieved through the application of a system of shared rules and is best defined as being based on the use of a model with variation and differing from primitive design in the extent of the variations. ${ }^{25}$ The thesis also supports Vellinga's argument that the vernacular should not be regarded as an architectural category consisting of static buildings that need to be carefully safeguarded but as a concept which identifies dynamic building traditions that continuously evolve while remaining distinctive to a specific place. ${ }^{26}$

Vernacular architecture has been linked to the 'primitive' human and the 'savage' states of society. ${ }^{27}$ Politicians and the populace of Malaysia alike perceive the vernacular as representing of a backward past, opposing their modern aspirations. ${ }^{28}$ Vernacular architecture is commonly seen as villages of simplistic mud huts located in the middle of tropical forests. ${ }^{29}$ Contrary to popular belief, the vernacular architecture of Malaysia is one of monumental and complex structures. The distinctions between the uses of spaces are blurred as these buildings are multipurpose and several activities and rituals occur under one roof. As a result of this, the thesis does not only focus on domestic buildings but covers a spectrum of building types which include civic, administrative, and commercial buildings, as well as recreational spaces.

The terms 'New vernacular' and 'Contemporary Vernacular Architecture" are starting to emerge in architectural theories and may sound like oxymorons. However, Heath has used the term 'new

\footnotetext{
${ }^{22}$ Encyclopedia of Vernacular Architecture of the World pxxi

23 Chen 'Architecture' The Encyclopaedia of Malaysia p11

${ }^{24} \mathrm{Lim}$ and Tan The New Asian Architecture. Vernacular Traditions and Contemporary Style p22

${ }^{25}$ Rapoport "Vernacular architecture and the cultural determinants of form" p286

${ }^{26}$ Asquith and Vellinga "Introduction" p9

${ }^{27}$ Encyclopedia of Vernacular Architecture of the World pxxiii

28 Encyclopedia of Vernacular Architecture of the World pxxiii

29 Beswick "Comments: Diary from Africa" unpaginated
} 
vernacular' to describe the end product of a collective and cohesive framing of ideas processed over time through a different regional filter. ${ }^{30}$ The new filter is the result of social, political, economic, technological and/or environmental influx affecting the locale. ${ }^{31} \mathrm{Lim}$ and Tan define the notion of 'contemporary vernacular' as 'a self conscious commitment to uncover a particular tradition's unique responses to place and climate, and thereafter to exteriorize these formal and symbolic identities into creative new forms through an artist's eye that is very much in touch with contemporary realities and lasting human values. ${ }^{32}$

Hybridization and intercultural exchanges play a major role in the evolution of the vernacular as the vernacular is constantly exposed to external influences and foreign cultures. Architects such as Robert Venturi speak of hybrid elements. Chris Abel uses the term 'hybrid architecture' in his writings and describes it as a process whereby different architectural styles interact to produce something new. ${ }^{33}$ The definition of 'hybrid architecture' in my thesis best resembles Abel's interpretation which describes such architecture as the product of the encounter between local cultures and the international system of exchange. ${ }^{34}$ Paul Oliver has written that cross cultural exchanges can only take place between two cultures which share enough common ground. ${ }^{35}$ If the two societies have entirely different world views, he argues, one set of ideologies would eventually overpower the other. This theory is apparent in the cultural interactions in Malaysian architecture because even though new cultures are introduced, the local cultural identities are not stripped away completely, but instead they go through a series of transformations and changes. Change is an important part of vernacular architecture because it is not a frozen notion of architecture.

\section{Changes to the vernacular form}

In this thesis I not only attempt to elucidate the process and progression of intercultural exchanges between vernacular architecture in Malaysia and the architecture of foreign cultures, but to also identify the responses and lifestyle changes these exchanges have generated. With the influx of foreigners and immigrants, and also the opportunity to travel overseas, we are exposed to places, cultures and ideas that are so very different from our own. The gift of travel has allowed us to discover unimaginable wonders. From the influences of these foreign cultures, we absorb aspects of their design and incorporate them into our own design vocabulary, applying these diverse principles

\footnotetext{
${ }^{30}$ Heath Vernacular Architecture and Regional Design p13

${ }^{31}$ Heath Vernacular Architecture and Regional Design $\mathrm{p} 13$

${ }^{32} \mathrm{Lim}$ and Tan The New Asian Architecture. Vernacular Traditions and Contemporary Style p23

${ }^{33}$ Abel Architecture and Identity Responses to Cultural and Technological Change p159

${ }^{34}$ Abel "Built Sources of Malaysian Identity" p40

${ }^{35}$ Encyclopedia of Vernacular Architecture of the World p72
} 
to the canvases of our own homes. ${ }^{36}$ These influences presented the local inhabitants of Malaysia with opportunities of an alternate lifestyle and prompted changes that would alter the vernacular house form. These changes have included: spatial and social organisation, the adoption of furniture and decoration and the abandoning of the traditional house.

\section{1) Spatial and Social Organisation}

In many Western and industrialized countries, activities such as sleeping, eating and/or cooking and bathing are appropriately differentiated by spaces that are used at particular times of the day. ${ }^{37}$ As seen in the traditional Malay house and the longhouses of Sarawak, spaces are defined through changes in level rather than partitions and walls. Most of these spaces are multi-purpose and not confined to one specific usage.

The wall is an essential element of built form by Western standards. Pieris wrote that the concept of the house as an individuated unit within a fenced compound and property ownership by a nuclear family, suggested affluence and colonial habits, where communal priorities were abandoned for a more private value system. ${ }^{38}$ Western families are accustomed to maximum privacy even among members of the same household therefore placing great importance on the division of private and public spaces. In contrast, the vernacular models reflect the importance of the nuclear family and are in favour of the intimacy of the community. ${ }^{39}$ The Malay and indigenous forms of dwelling retained communal sleeping and living and also lack in subdivisions such as fences and gates.

The introduction of walls in vernacular architecture increased proportions of private and personal space. These barriers generate the formation of new living traditions and social behaviours which result in the introversion of family life.

2) Adoption of Furniture and Decoration

Furniture is an integral part of the Western lifestyle. Acknowledged as a display of status and economic well being, traditional Malaysian houses gradually included furniture. ${ }^{40}$ Now it is not an unfamiliar sight to see lavish settees and dining tables in the traditional Malay house. This however does upset the ergonomics of the traditional house as the low

\footnotetext{
${ }^{36}$ Waller and Bradbury Fusion Interiors p1

${ }^{37}$ Encyclopedia of Vernacular Architecture of the World p72

${ }^{38}$ London, Houses for the $21^{\text {st }}$ Century p42

${ }^{39}$ Abel Architecture and Identity Responses to Cultural and Technological Change p152

${ }^{40}$ Ismail Houses in Malaysia. Fusion of the East and the West p41
} 
headroom was intentionally built to suit people eating and sitting on the floor. The use of modern furniture has led to the shifts in houseforms such as the bumbung lima and bumbung perak which have higher headroom. ${ }^{41}$ It has also changed the traditional characteristics of a Malay house which were known for their large open and uncluttered interiors. ${ }^{42}$ It is also becoming gradually more common to find a range of contemporary consumer products such as television sets and other household appliances tucked in the inner apartments of the longhouses.

Some modern Malay houses have also introduced the use of coloured linoleum tiles to cover the floor. This tampers with air flowing through the slits of the flooring boards. ${ }^{43}$

3) Abandoning the Traditional House

The term "traditional" usually carries with it connotations of backwardness; of being limited by history and precedents. "Vernacular architecture" is often dismissed as being crude and unrefined construction. The negative connotations of the word 'traditional' diminish the status of such vernacular houses. As Ismail has pointed out, the Malaysian mindset is that these wooden houses are fit for only poor people living in villages. Wooden houses are linked to poverty and the lower class society while modern concrete houses are linked to prestige and suited to people with a higher standard of living. ${ }^{45}$ The act of moving to the urban areas and abandoning the traditional house becomes recognition of financial and social success.

The vernacular architecture of Malaysia was based on certain degrees of communal living. Although the Malay house is a detached form, the Malays traditionally were in favour of intimacy at the level of community as reflected by the open settlement plan of the village. The indigenous people of Sarawak, for example, found safety in numbers as part of a survival tactic from enemy attacks or the difficult environment. ${ }^{46}$ Upon adapting to their new environment, the European settlers such as government official, merchants and planters resided in detached models such as bungalows and villas, to duplicate the suburban lifestyles of their homeland.

\footnotetext{
${ }^{41}$ Lim The Malay House p135

${ }^{42}$ Lim The Malay House p135

${ }^{43}$ Ismail Houses in Malaysia. Fusion of the East and the West p42

${ }^{44} \mathrm{Lim}$ and Tan The New Asian Architecture. Vernacular Traditions and Contemporary Style p13

${ }^{45}$ Ismail Houses in Malaysia. Fusion of the East and the West p43

${ }^{46}$ Tettoni and Ong Sarawak Style p17
} 
As Kent has noted, the physical and psychological opportunities for privacy increase as a society moves from 'primitive' to 'modern'. ${ }^{47}$ Eventually, the local inhabitants followed suit shifting from communal dwelling and constructing mansions and villas of their own. Success and prosperity compelled the Chinese to move out of their shophouses into detached bungalows. In the late nineteenth century, a significant number of Chinese undertook this unknown private lifestyle and lived in mansions which designs were essentially inspired by European classical forms and traditional Chinese house plans.

When talking about change, it is important to distinguish between change as continuity and change as disruption.

\section{Chapter Summaries}

The thesis examines these issues in five chapters which provide an historical account of three stages of Malaysian vernacular architectural history: pre-C16 ${ }^{\text {th }}$ vernacular architecture, mid-C16 $6^{\text {th }}-$ mid-C $20^{\text {th }}$ architecture, and post independence architecture (mid- $220^{\text {th }}$-present day). The aim of these chapters is to provide an understanding of the complex inter-cultural exchanges which has occurred in all three stages of Malaysian architectural history.

\section{Chapter 1: Malaysian Vernacular Architecture Part I (pre-16 ${ }^{\text {th }}$ century)}

The first chapter provides a detailed description on the origins and common characteristics of the traditional Malay house. The thesis recognises that the Malay house, although considered vernacular to the region, is not 'pure' in its origins and has characteristics similar to dwellings found throughout Southeast Asia. The process of hybridization is a prevailing concept as the structures that are considered vernacular to the region have been exposed to layer upon layer of imported cultures which had been localized over time.

The lack of walls and partitions in the Malay house did not mean that the distinctions between public and private domains do not exist but rather, barriers are marked through behavior and mutual understanding among the inhabitants. The daily routinized behaviour of individuals also provides them with an understanding of what activities take place in spaces during specific times of the day and night as the spaces within the houses are not defined and confined to one specific use.

\footnotetext{
${ }^{47}$ Kent Domestic architecture and the use of space p 50
} 
The chapter discusses the social and spatial organisations of each of the traditional houses and the ways in which status and hierarchy is demonstrated within the community. Indicators of status and prosperity included the increase in size, ornamentation, material possessions and the use of modern building materials. In understanding the vernacular, we are able to be conscious of how the theories of modernity and the traditional are in flux.

\section{Chapter 2: Malaysian Vernacular Architecture Part II (pre-16 ${ }^{\text {th }}$ century)}

The second chapter, a continuation of the first, introduces the longhouse of the indigenous groups of Sarawak (which includes the Iban, Melanau, Bidayuh and Orang Ulu). Although longhouses are the archetypical form of Borneo domicile, this form of dwelling exists in other parts of the world. ${ }^{48}$ This indicates that the longhouse could also be a product of intercultural exchanges, contributing to the notion that the definition of vernacular architecture is continually evolving and part of an ongoing process of relocation, transformation and adaption.

The spatial and social organization of the longhouse is not as straightforward and simple as it appears to be. As longhouses are considered to be multi family dwelling, it may seem that there is a lack of regard toward privacy within the confinement of the single roof structure. However, the organization of time, space and people interrelates with deeper concepts of social value concerning gender, age and status as well as more abstract values of privacy and community. ${ }^{49}$ The chapter will also discuss the ways in which power and hierarchy is manifested within the longhouses.

The studies of both these vernacular building types reveal cultural ideas, meanings and implications as well as establishing the complex identities of these monumental structures.

\section{Chapter 3: Foreign Influenced Architecture Part I (1511-1957)}

The third chapter identifies the cultural exchanges that occurred as a result of the arrival of the Chinese community and the Colonial regimes, during which diverse cultures and lifestyles were introduced to the country. Upon their arrival in Malaya, the Chinese immigrants, as well as the Portuguese, Dutch and British rulers, brought with them their homeland traditions which were reflected in their administrative buildings and domestic architecture.

The Chinese make up one of the major immigrant groups in Malaysia, permanently settling in Melaka in the seventeenth century. The settlers who were mainly shopkeepers, craftsmen and

\footnotetext{
48 Alexander "The Lahanan Longhouse" p31

${ }^{49}$ Encyclopedia of Vernacular Architecture of the World p72
} 
farmers, brought with them building types, such as shophouses, townhouses, temples and the kongsi (clan house), and architectural influences which led to the development of the Straits Eclectic style. The Straits Eclectic style is the fusion of Chinese, European and Malay architecture and is mostly evident in the façade of shophouses and terrace houses. ${ }^{50}$ The Chinese building types were multifunctional, combining residential and commercial spaces in the form of the shophouses and the clan house.

The colonial regime erected monumental structures, intended to impose dominance over the local inhabitants. In colonial cities, the relationships between the dominator and the dominated are clear. ${ }^{51}$ Power is displayed through scale, complexity in design, use of imported building materials and the introduction of building types that had no local parallel.

The chapter questions the definition of the term vernacular and the role it plays within the context of foreign influenced architecture. The chapter also explores the similar and conventional concepts imbued within vernacular architecture that allow for new building types to be easily comprehended. This included the ways in which power and hierarchy is manifested.

\section{Chapter 4: Foreign Influenced Architecture Part II (1795-1957)}

The fourth chapter investigates the buildings of British colonial period and their response to the regional dynamics and cultural exchanges. The British Empire introduced various architectural styles to the region, which included Moorish influences, Tudor Revival, Neo- Classical and the Neo Gothic style. The English lived in detached residences such as colonial bungalows and villas. However, distinctions can be made between the colonist who abided by their traditions, representing power and exerting authority, and the settlers who retained some loyal values but also sought a new life and new opportunities. ${ }^{52}$ The foreign settlers to the country were also willing to converge, compromise and adapt to their new environments, particularly to the tropical climate.

The process of adaptation to the tropical climate and the other contextual needs involved significant cross-cultural exchanges, resulting in hybrid architecture. The chapter identifies the architectural strategies and devices adopted by these foreigners in combining local and foreign architectural

\footnotetext{
${ }^{50}$ Ho, Hasan, and Noordin “An Influence Of Colonial Architecture To Building Styles And Motifs In Colonial Cities In Malaysia" unpaginated

${ }^{51}$ AlSayyad Forms of Dominance $\mathrm{p} 5$

${ }^{52}$ Oliver Built to meet needs. Cultural Issues in Vernacular Architecture p169
} 
ideas. It also examines the changes to the role and form of the vernacular throughout these processes of relocation, transformation and modification.

\section{Chapter 5: Contemporary Malaysian Architecture (1957-present)}

The final chapter investigates the spread as well as the consequences of the arrival of the International Style on Malaysia's contemporary buildings. Initiatives such as the Colombo Plan contributed to the spread of modernism in the country as the scholars returned from abroad and demonstrated philosophies of architecture which were largely oriented towards a Western perspective. The education which taught the values of external cultures had a significant influence on attitudes towards indigenous culture. ${ }^{53}$

Western architecture has set many precedents in design and technological innovation in the country. The 1950s and 1960s was a period of re-evaluating the fundamental principles of the International Style. ${ }^{54}$ Local architects started to question the validity of international models in the country.

The chapter states that while the characteristics of the European models of Modernism do not exemplify the concepts of the vernacular, it is the hybridisation of the international and local forms that generates a 'new vernacular'. The chapter will identify the architectural strategies employed by local architects in an attempt to revive and capture the qualities of traditional architecture and retain a national identity.

\section{Conclusion}

The thesis concludes that Malaysia's complex architectural identity lies in a creative process of cultural cross-fertilization and localization of imported models, rather than of purified identities. The presence of the vernacular lingers within the evolving cross cultural narrative of Malaysian architecture. No longer does the term only speak of the past and the primitive, but instead is accepted as an ongoing process which changes over the course of time to reflect choices people have made in response to new regional realities.

\footnotetext{
${ }^{53}$ Encyclopedia of Vernacular Architecture of the World p122

54 Chen 'Architecture' The Encyclopaedia of Malaysia p106
} 


\section{Chapter 1: Malaysian Vernacular Architecture Part I (pre-16 ${ }^{\text {th }}$ century)}

The Malay house is the traditional house form of the Malay race in Malaysia and is most commonly found in West Malaysia. The distinctions between the public and private domains as well as the purpose of spaces in the Malay house may not appear to be obvious as there is little emphasis on elements such as walls and doors to signal this social organization.

This chapter will cover issues regarding social and spatial organization as well as vernacular expressions of power and status. Closer inspection of the social and spatial organisation of these vernacular dwellings suggests similarities between traditional and Western characteristics of society. The chapter also leads to a discussion on the definition of vernacular as a hybrid product of intercultural exchanges.

\section{Origins of the Traditional Malay House}

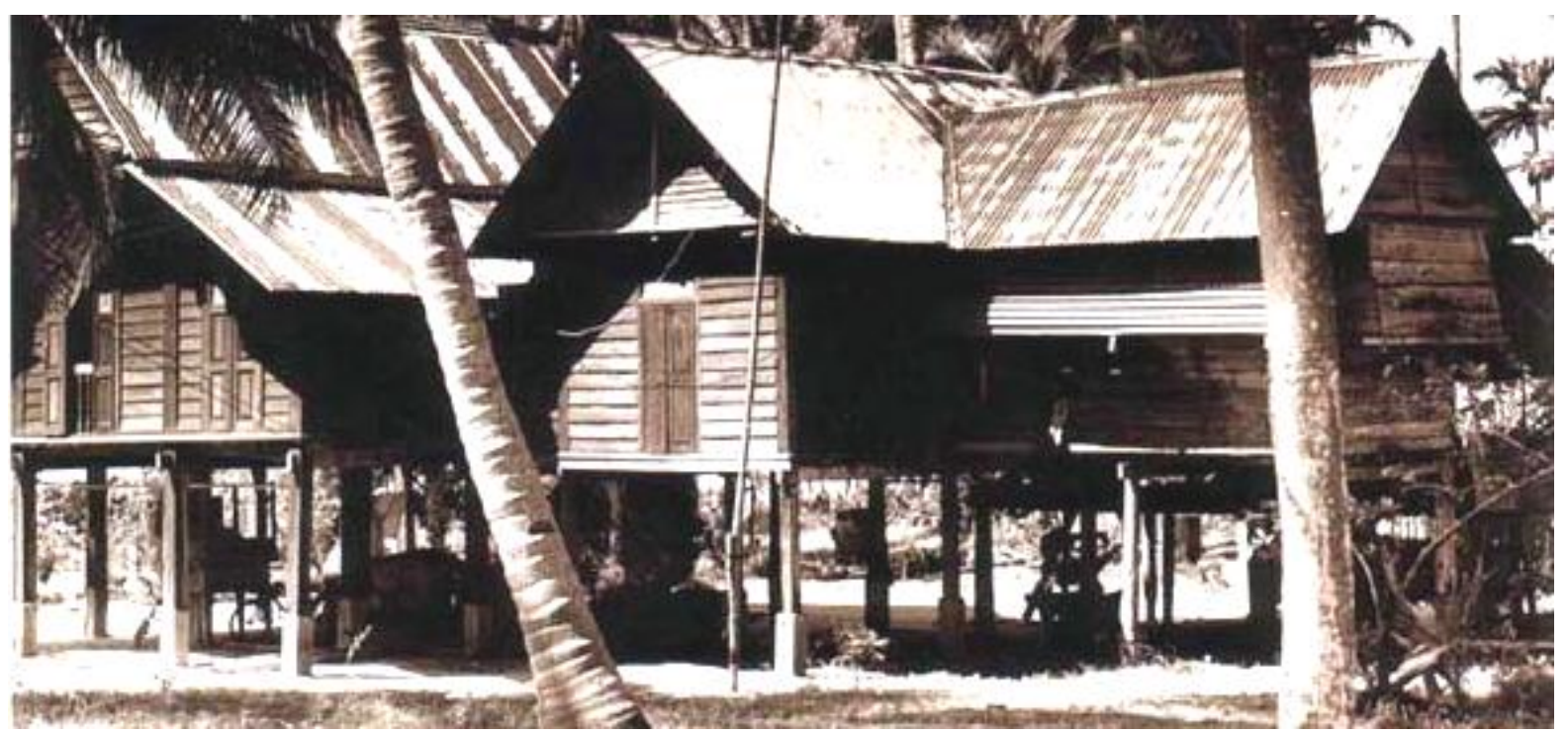

Fig 1.1 The traditional Malay house

Malaysia's vernacular houses are post and beam structures raised on stilts with gabled roofs. The house type is ubiquitous as many other houses throughout South East Asia share similar features such as the saddle roof, gable horns and raised floor with timber posts. The Malay house is said to have originated in various islands of the Malay Archipelago (now known as Indonesia) and share recurrent features which are similar to dwellings found throughout Southeast Asia and as far as Micronesia and Madagascar. ${ }^{55}$

\footnotetext{
${ }^{55}$ Chen 'Architecture' The Encyclopaedia of Malaysia p14
} 
Variations of Malay houses found in Malaysia illustrate similar roof styles to houses in neighbouring countries such as Thailand, Vietnam, Cambodia, Laos and Indonesia. This contributes to the theory that these vernacular houses share a common origin. ${ }^{56}$

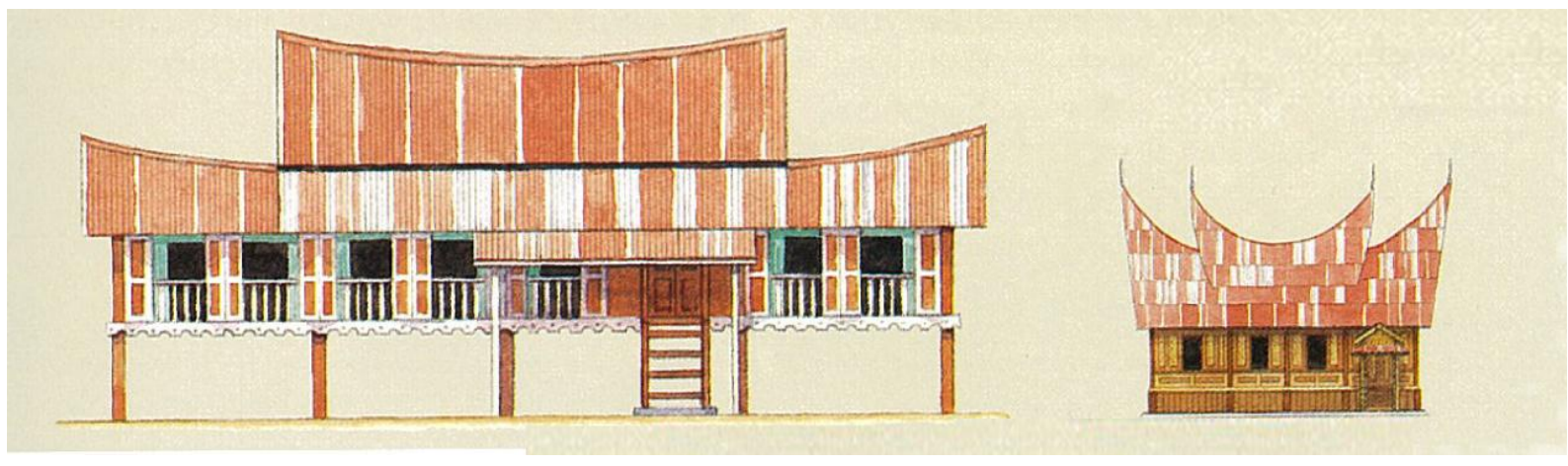

Fig. 1.2 The roof style of the Minangkabau-style house in Negeri Sembilan (left) is believed to be influenced by the Sumatran house in Indonesia (right).

\section{Common Characteristics}

Malay houses are usually constructed by local carpenters or craftsmen and sometimes the owners themselves. These houses are placed in village-like settlements known as the kampung which have few landmarks and may look haphazard to foreign observers upon first encounter. The houses found in paddy lowlands are scattered in clusters and are usually demarcated by coconut trees, fruit plantations and vegetation, which shade the house from direct solar radiation. The linear settlement patterns usually form along rivers, roads and sandbanks. The external environment is communal and as untouched as possible. There are no physical boundaries to define trespassing and only gravel paths lead the way from house to house and from house to public buildings. This preference for community intimacy over personal privacy led to stronger and closer ties in the village. The Malay nuclear family, consisting of husband, wife and dependent children, make up the social grouping of the house. However, in cases where people cannot afford to construct individual houses, or if land is scarce, the Malay house accommodates the elaborate extended family which includes parents, grandchildren and other relatives. ${ }^{57}$

The traditional Malay house is organized in a hierarchical order, expressed in the arrangement of spaces, height and volume. The most space and highest level of the house is dedicated to the more important spaces while the less important spaces are smaller in size and lower in level. The changes

\footnotetext{
${ }^{56}$ Chen 'Architecture' The Encyclopaedia of Malaysia p17

${ }^{57}$ Lim The Malay House p84
} 
in level also define spaces rather than partitions and walls. The areas in the Malay house are not named by a specific use e.g. living room, dining room, bedroom, etc. as the same spaces are used for multiple purposes during different times of the day and year. The orientation of the site is not determined by the presence of basic infrastructure such as water, roads and electricity supply. Instead, the selection of a house site is always done according to observations and religious rituals. This is to ensure that wandering spirits are appeased and the house occupants will lead a harmonious life. ${ }^{58}$ This is determined by a religious ceremony based on an elaborate code of rules. When a site complies with favourable conditions, construction begins and the tiang seri (main column) is erected. The tiang seri represents the centre of the house and is blessed by prayers

The leader of the Malay village is the penghulu (village headman). The penghulu was also the intermediary between the people of the village and the higher authority of the land such as the colonists. ${ }^{59}$ The headman's house is not isolated from the other houses in the village but differs in size and detail as McNair describes:

But it is the building of a chief's house that the best efforts are put forth; and very picturesque are some of the efforts in this way, with their neat thatching, matted windows and elegantlywoven sides, gracefully shadowed by the beautiful growth of palms; though there are irreverent Englishmen found ready to make comparisons between these jungle palaces and their barns of their native land. ${ }^{60}$

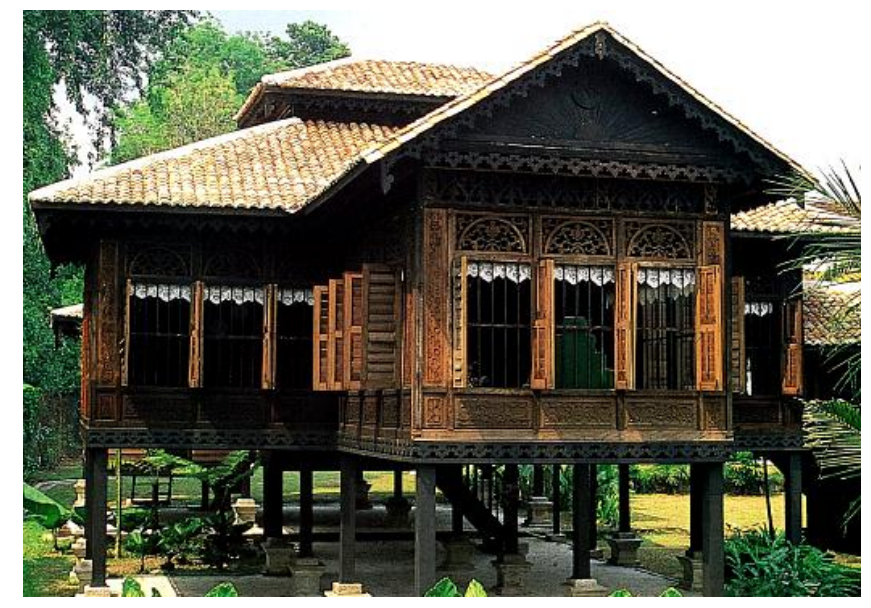

Fig. 1.3 The headman's house in a village in Kedah

The Malay house is primarily a timber post and lintel structure and raised on stilts and resting on concrete or stone footings. The components are prefabricated and later assembled on site. The materials for the building are usually found in the immediate surroundings and have low thermal capacity. The main structure (the posts, crossbeams, tie beams and roof structure) are made of hardwood such as cengal (Neobalanocarpus heimii), belian (Eusideroxylon zwagerii), merbau (Intsia palembanica) or resak (Vatica spp) while the secondary

\footnotetext{
${ }^{58}$ Chen 'Architecture' The Encyclopaedia of Malaysia p23

${ }^{59}$ The Politics of Civic Space in Asia: Building Urban Communities p97

${ }^{60}$ Waterson The Architecture of South-East Asia through Travellers' Eyes p204
} 
structure (the rafters, floor joists, wall studs, window frames and door frames) and other nonstructural members are made of moderately hard timber such as meranti (Shorea spp.) and jelutong (Dyera costulata). ${ }^{61}$ These are assembled with detachable components such as timber dowels and wedges instead of nails and bolts.

The design of the Malay house provides a direct response to the vagaries of the local climate. Numerous voids, provided by the raised stilts, full length windows, grilles and panels, ensure adequate ventilation in the interior of the house, which is the most important relief to climatic stress in Malaysia. ${ }^{62}$ Low windows shaded by large overhangs reduce glare from the skies. Grilles and wooden panels also control the occurrence of glare by dispersing large bright areas into tiny ones. ${ }^{63}$ One of the most distinctive features of the Malay house is its high-pitched and gabled roof to facilitate water drainage during rainfall and to provide a large ventilated roof space below which allows warm air to dissipate and cool. ${ }^{64}$ This lightweight roof is made of various types of thatch such as nipah (palm), rumbia (sago plant) and bertam palm tree. ${ }^{65}$ Thatch strips, measuring approximately 6 feet long and 16 inches wide, are tied to a bamboo or wood spine, which is then tied to the rafters to form the roof. ${ }^{66}$ Now more houses use galvanized iron or zinc sheets for roofing because of their durability, although the traditional roof form has been retained.

The Malay house comprises a back and front portion which revolve around the rumah ibu (core house) and the dapur (kitchen) respectively. Stairs at the entrance lead up to the entrance anjung (porch) which serves as an important transition point between public and private domains. ${ }^{67}$ This is where unfamiliar visitors to the house are initially greeted and house occupants lounge and observe passers-by. Once the occupants are warmed up to the visitors, they are invited to enter the serambi gantung (verandah) which connects the front porch and the core house. The floor level is raised about 7 inches moving into the core house, which is the highest, largest and most active space of the house. Praying, sleeping, sewing, ironing, studying and feasting are activities that commonly take place in the core house. On the other side of the core house, a closed serambi samanaik (verandah) connects to the selang (walkway). The closed verandah is used for praying, sleeping and resting. ${ }^{68}$ The selang is generally the domain where women socialize. A staircase leading up to a secondary

\footnotetext{
${ }^{61}$ Chen 'Architecture' The Encyclopaedia of Malaysia p22

62 Lim The Malay House p73

${ }^{63}$ Lim The Malay House p73

${ }^{64}$ Kamal, Kamarul Syahril and Wahab, Lilawati Ab. "Adaptation Design of Traditional Malay House to Meet the Requirements of Comfort Living in Modern Houses" unpaginated

${ }^{65}$ Lim The Malay House p102

${ }^{66}$ Lim The Malay House p102

${ }^{67}$ Lim The Malay House p36

${ }^{68}$ Lim The Malay House p36
} 
side entrance is also located here. The kitchen is located at the back of the house and is mainly the women's territory where women congregate, prepare food and cook, and where the family dines. The cooking area consists of a simple wooden firebox. ${ }^{69}$ A pelantar (platform) attached to the kitchen, is used for washing clothes, vegetables and cooking utensils. ${ }^{70}$ The floor of the platform is made out of tree trunk halves and laid in slits in between to allow water to drain through to the ground beneath. Some Malay houses, particularly in Melaka, have courtyards which are an intimate, private interior open space between the core house and the kitchen. ${ }^{71}$ Women do their washing, drying and sometimes the entertaining of guests here.

However, customary laws restrict male-female relationships for younger people, and women and men are separated in all formal social interactions. ${ }^{72}$ This is marked by the clear domains formed within the Malay house. The male domain usually consists of the front part of the house while the back portion is usually occupied by the women. Young women are usually kept away from the public domain of the house. The Malay house corresponds to this tradition by including a side entrance that allows the women direct access to the back of the house without passing through the male domain.

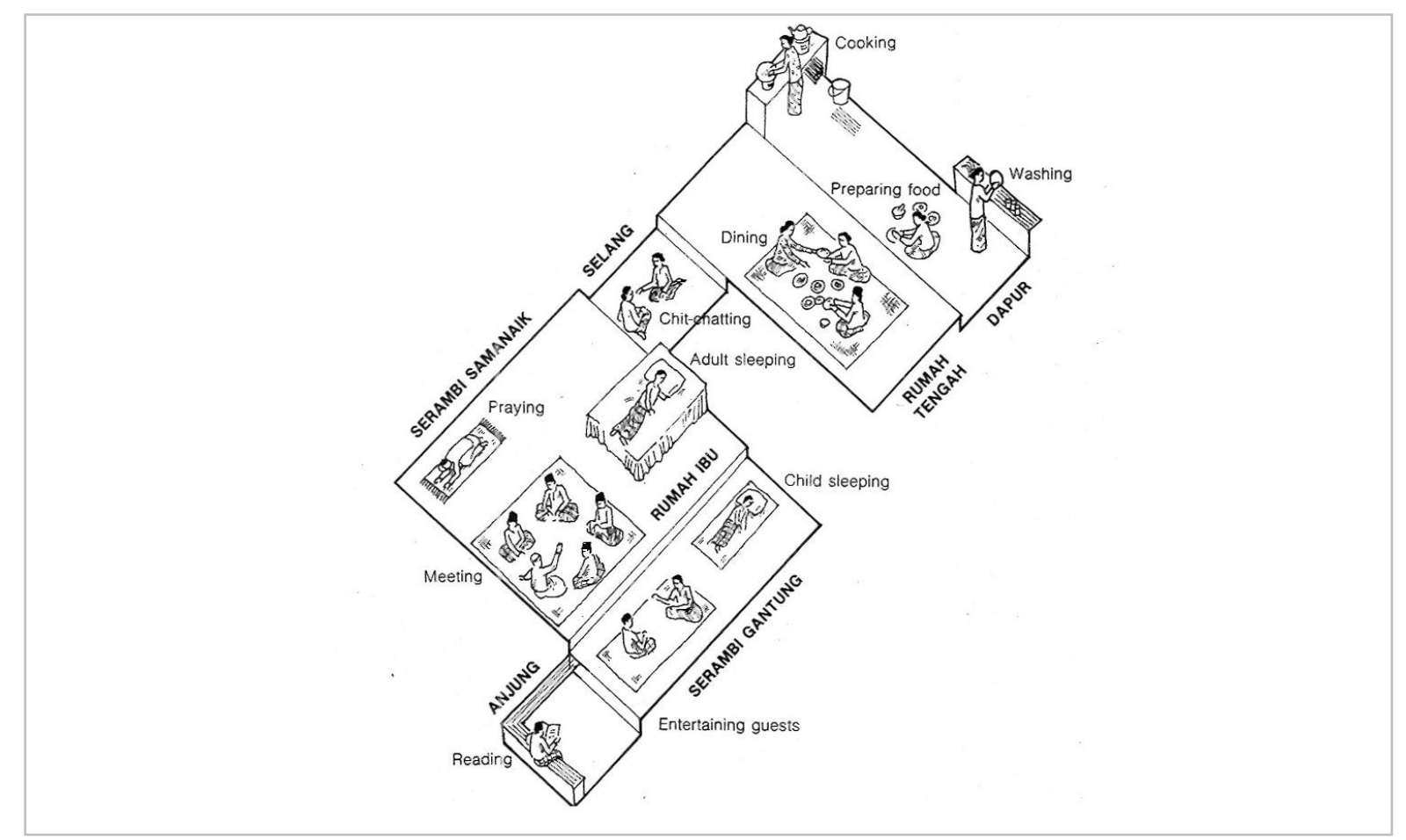

Fig. 1.4 Diagram illustrating the use of interior spaces in the Malay house

\footnotetext{
${ }^{69}$ Chen 'Architecture' The Encyclopaedia of Malaysia p21

${ }^{70}$ Ismail Houses in Malaysia. Fusion of the East and the West p14

${ }^{71}$ Lim The Malay House p39

72 Lim The Malay House p 82
} 
The roof spaces of the houses are usually left exposed. Sometimes the roof space is converted into a loceng (attic). The attic was once used as a sleeping place for the younger women but is now utilized as storage space. ${ }^{73}$ The wooden floors are nailed to the floor joints and are spaced to leave gaps to allow for water and dirt to fall through to the ground. The doors are simple wooden swing doors that are beautifully adorned with carvings. The windows are closed by railings and are full length, dropping down to the floor level to provide good cross ventilation and unobstructed exterior views.

The Malay house is subtle and functional, with the only apparent aesthetic considerations given to the wood carvings and other embellishments of the house. Sleeping, sitting and resting are carried out on the floor. Occasionally, a small bed of bamboo or wood is made for pregnant women. Iron bedsteads are also traditionally used by newly married couples. ${ }^{74}$ Food is served on mats laid out on the floors with people sitting around the food. Curtains are sometimes used to create partitions. Water services, for bathing and toilet activities, are located outside the house.

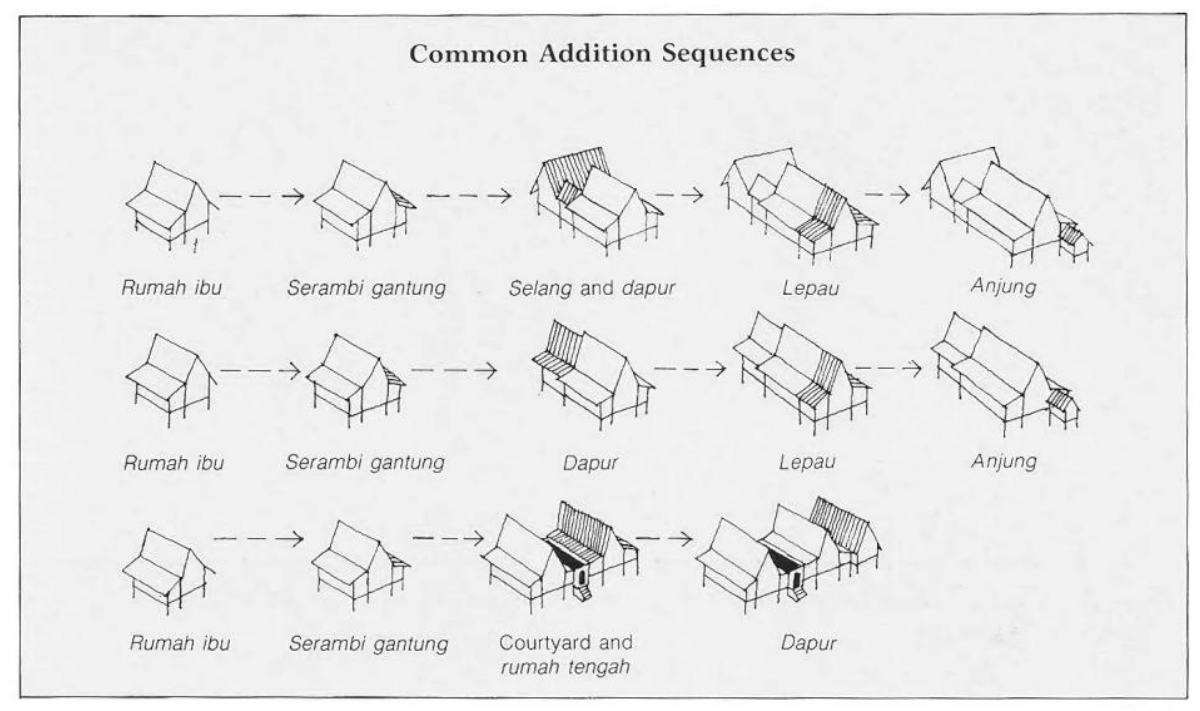

Fig. 1.5 Diagram showing common addition sequences of the traditional Malay house

The design of the Malay house allows for the flexible expansion of the house when the family grows in size and prosperity or when there is a desire for a more comprehensive dwelling space. These extensions follow a sophisticated system of principles that integrate and grow with the core house. ${ }^{75}$ During the extension process, there is minimum demolition and maximum utilization of materials and resources such as wall panels, doors and windows. ${ }^{76}$

\footnotetext{
${ }^{73}$ Lim The Malay House p39

${ }^{74}$ Lim The Malay House p86

${ }^{75} \mathrm{Lim}$ The Malay House p118

${ }^{76}$ Lim The Malay House p128
} 


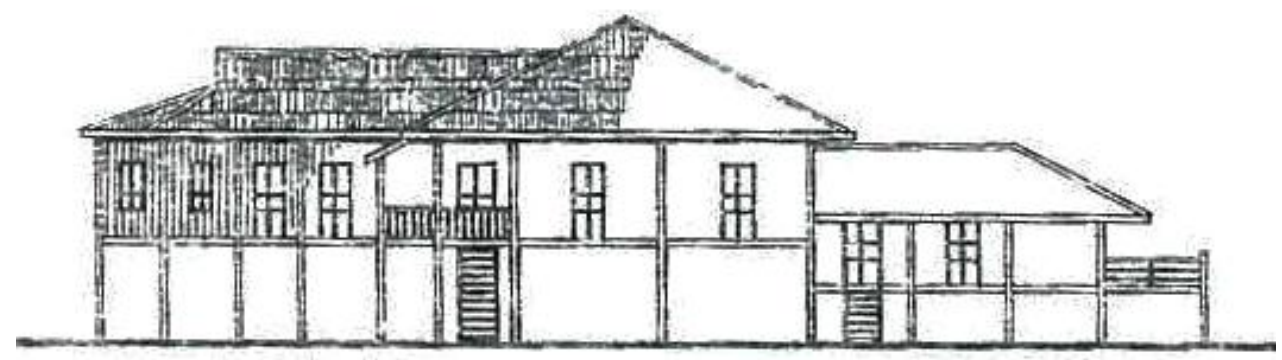

FRONT ELEVATION

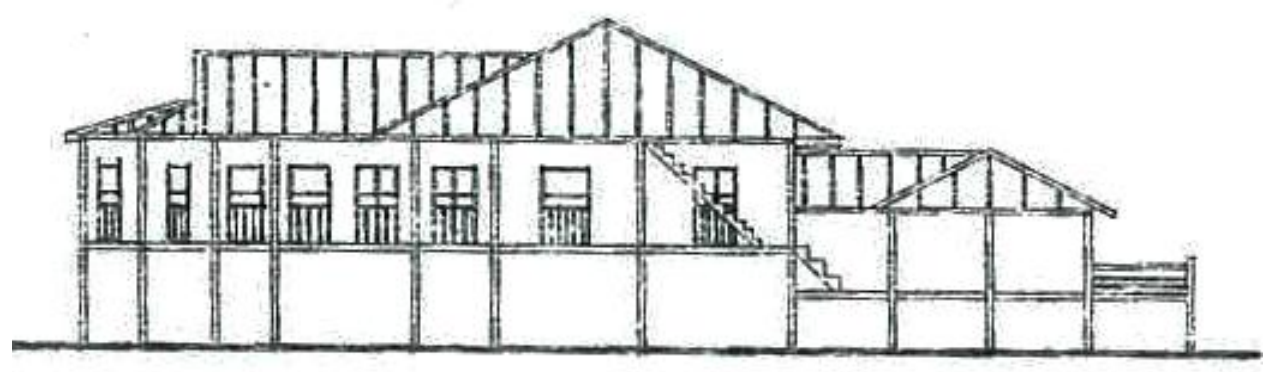

SECTION A-A

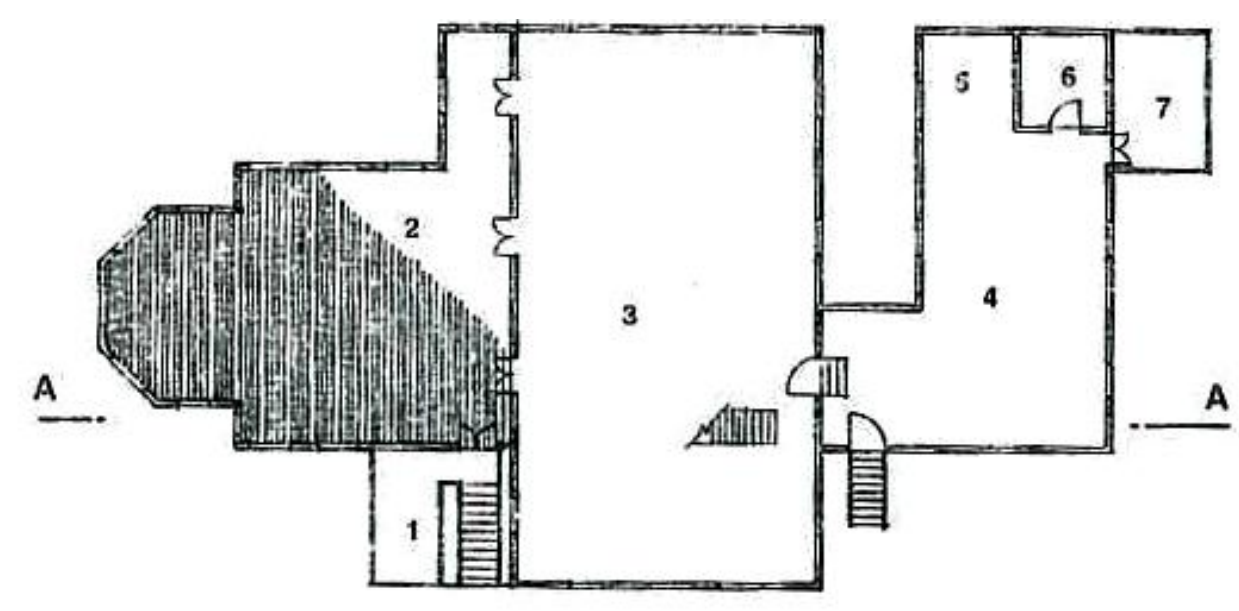

FLOOR PLAN

KEY

1. Verandah

2. Luar (Living Area)

3. Tengah (Sleeping Area)

4. Dapur (Dining Area)

5. Kitchen

6. Amenities

7. Open Washing Area

Fig. 1.6 Diagram illustrating front elevation, section and plan of the Malay house 


\section{Regional Variations}

There are distinct regional variations of the Malay house found in different parts of Peninsular Malaysia. Each of these houses reflects the qualities of the cultural groups which came to settle in different parts of the mainland and have evolved to include features which were sometimes influenced by immigrants to Malaya.

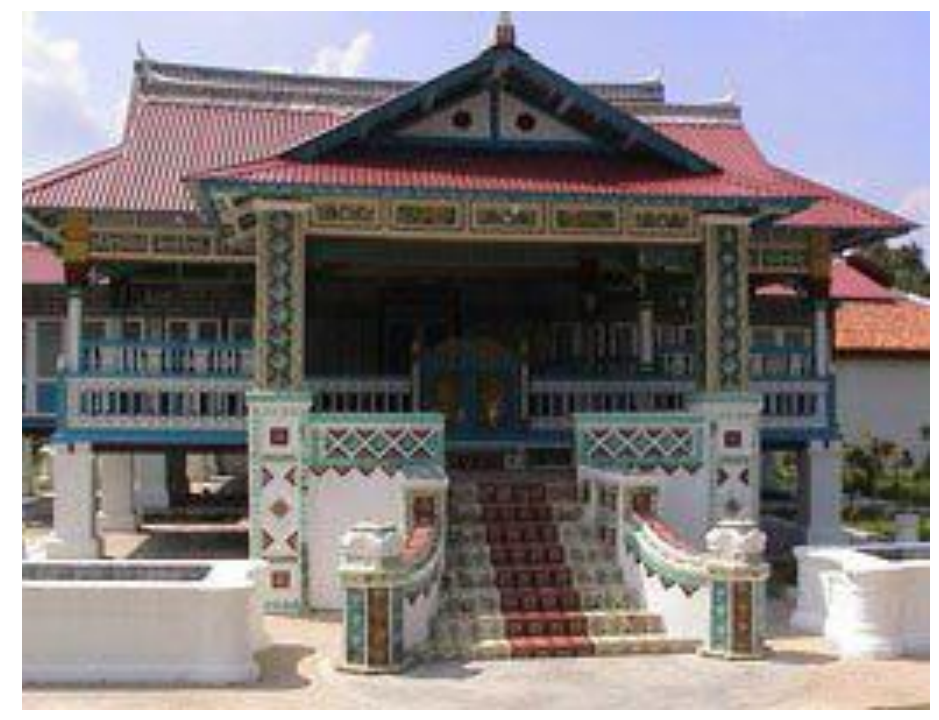

Fig. 1.7 The Malay house of the village headman in Merlimau, Melaka.

The Malay house in Merlimau, Melaka (fig) was built in 1900 by two local carpenters and a carpenter from Kelantan. The house was constructed for village headman, Abdul Ghani. As the village headhouse, the house was extensively decorated. ${ }^{77}$ The design, embellishments and decorations of the house are heavily influenced by Chinese immigrants. ${ }^{78}$ These 'hybrid' Malay houses feature distinctive ornamental glazed ceramic tiled stairways at their entrances. These colourful tiles are imported from Europe or China and are also found on the facades and interior of Melakan townhouses. ${ }^{79}$ These stairs are either located at the front or lead to the courtyard. The arrangement of courtyards and the high-ceilinged rooms reveals the Portuguese influence on the Melakan Malay house.

Other regional variations of the Malay houses have also developed through foreign influences. The basic form, plan and construction methods are similar but the houses can be differentiated by their roof shapes. The bumbung lima and bumbung perak houses appear to show foreign qualities that are identified as Dutch and British. The bumbung lima, or "five ridged roof" is influenced by European house styles of the colonial period. ${ }^{80}$ This variation of the Malay house included concrete

\footnotetext{
${ }^{77}$ Yeang The Architecture of Malaysia p110

${ }^{78}$ Lim The Malay House p48

${ }^{79} \mathrm{Chen}$ 'Architecture' The Encyclopaedia of Malaysia p25

${ }^{80}$ Chen 'Architecture' The Encyclopaedia of Malaysia p25
} 
staircases, masonry columns, full length louvred shutters as well as the roof types that have higher headroom which allowed for the introduction of furniture. ${ }^{81}$
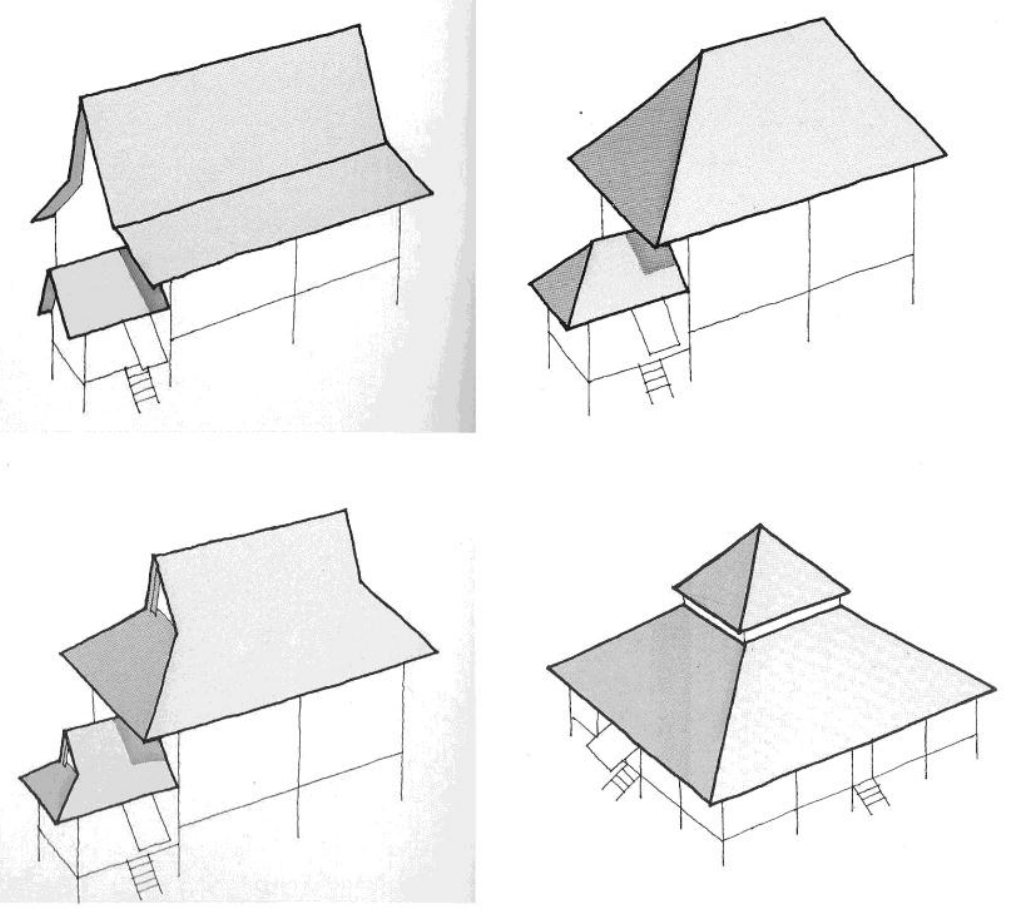

Fig. 1.8 Diagram showing the various types of Malay house-bumbung panjang (top left), bumbung lima (top right), bumbung perak (bottom left) and bumbung meru 2-tingkat or 2-teired pyramidical roof (bottom right).

\section{Changes in building materials}

Due to the increases in population and the scarcity of resources, alternatives are increasingly used in place of the traditional building materials. During the Japanese occupation, thatch, which was the main building material of the roof of the Malay house, was heavily exhausted to meet the temporary building needs of the Japanese. ${ }^{82}$ When the British regained colonisation in 1945, they introduced galvanized iron sheets to substitute for the lack of thatch. ${ }^{83}$ The use of zinc proved unsuitable as it has high thermal conductivity, which is undesirable in the hot climate of Malaysia.

Modern Malay houses have replaced adjustable full length wooden windows with movable glass louvre windows fitted with iron bars. The glass windows were preferred for aesthetic reasons or to allow views from outside while maintaining the inhabitant's privacy and security. ${ }^{84}$ This change alters

\footnotetext{
${ }^{81}$ Chen 'Architecture' The Encyclopaedia of Malaysia p25

82 Ismail Houses in Malaysia. Fusion of the East and the West p43

83 Ismail Houses in Malaysia. Fusion of the East and the West p43

${ }^{84}$ Hashim, Rahim, Rashid and Yahaya "Visual privacy and Family Intimacy" p309
} 
a unique characteristic of the Malay house which relied on its airy and open qualities. Some houses have also started to replace wood with cement and bricks. These new materials allow wet areas, such as the kitchen, to be easily cleaned and maintained. However, this change in material significantly alters the house form with the kitchen being grounded and not raised on stilts. ${ }^{85}$ The modern Malay houses also integrate water and toilet services in the houses, which were traditionally located outside of the houses. This decreases social activity, isolating women from one another as they are no longer required to meet at public wells to gather water. ${ }^{86}$

\section{Chapter Conclusion}

Life in the Malay village, although in separate households, relies on communal lifestyles and social interactions. The concepts of sharing and cooperation are fundamental to the Malay culture as occasions such as weddings become a village affair rather than a household celebration. ${ }^{87}$ Within the structures of these traditional houses, there is a lack of internal walls and partitions to separate spaces. It is possible to conclude that the absences of these walls might imply the absence of privacy concerns but privacy is manifested differently in different cultures. The rules and symbols of privacy controls influence the flow of information and communication at individual, group and social levels. ${ }^{88}$ Conventionally, the structure of privacy is expressed by the relation between interior and exterior spaces and by comparing barriers and boundaries. However, in the houses of the Malays these boundaries are invisible.

Privacy is achieved through behaviour. For example, privacy can be controlled through the communication of strict rules or by organising activities in time. ${ }^{89}$ Daily routines became a major part of spatial and social organisation. As the interior spaces of the Malay house are not confined to one specific use, routine controls how these spaces are used throughout the day.

Although there are no external boundaries in the village compound, it should be noted that the Malay houses have a boundary between the interior of the home and the external environment which serves as threshold. This is seen in the anjung (porch), where guests are initially greeted. There are also cultural conventions that establish gender territories within the household. In both the Malay house and the longhouses discussed in chapter 2, there is a clear distinction of space in

\footnotetext{
${ }^{85}$ Lim The Malay House 135

${ }^{86}$ Encyclopedia of Vernacular Architecture of the World p72

87 Chen 'Architecture' The Encyclopaedia of Malaysia p19

${ }^{88}$ Kent Domestic architecture and the use of space p50

${ }^{89}$ Encyclopedia of Vernacular Architecture of the World p72
} 
relation to gender. In the Malay house, the rear of the house is regarded as the domain of the female while the front part of the house is occupied by the male.

Status and hierarchy in the village is expressed through physical forms. This includes the significant increase in size and ornamentation, the adoption of material possessions and furniture, and the replacement of traditional building materials with modern materials.

The traditional Malay house provides an understanding of the nature of architectural continuities. Although it originated and evolved from diverse precedents, it has come to function in its own respective role as Malaysian vernacular architecture. 


\section{Chapter 2: Malaysian Vernacular Architecture Part II (pre-16 ${ }^{\text {th }}$ century)}

The longhouse exists all over Borneo and is sometimes referred to as 'an entire village under one roof' as it is designed to accommodate several nuclear families under a single monumental structure. $^{90}$ These houses exemplify the potential of co-operative construction and represent the communal lifestyles of indigenous groups such as the Iban, Melanau, Bidayuh and Orang Ulu. ${ }^{91}$ The longhouse is usually situated within close proximity to a river and parallel to its course. The river provides the village with the primary source of food and fresh water as well as a means of transportation. The chapter will look at the longhouses of the four indigenous groups in separate sections, in terms of social and spatial organization as well as ways in which power and status are manifested.

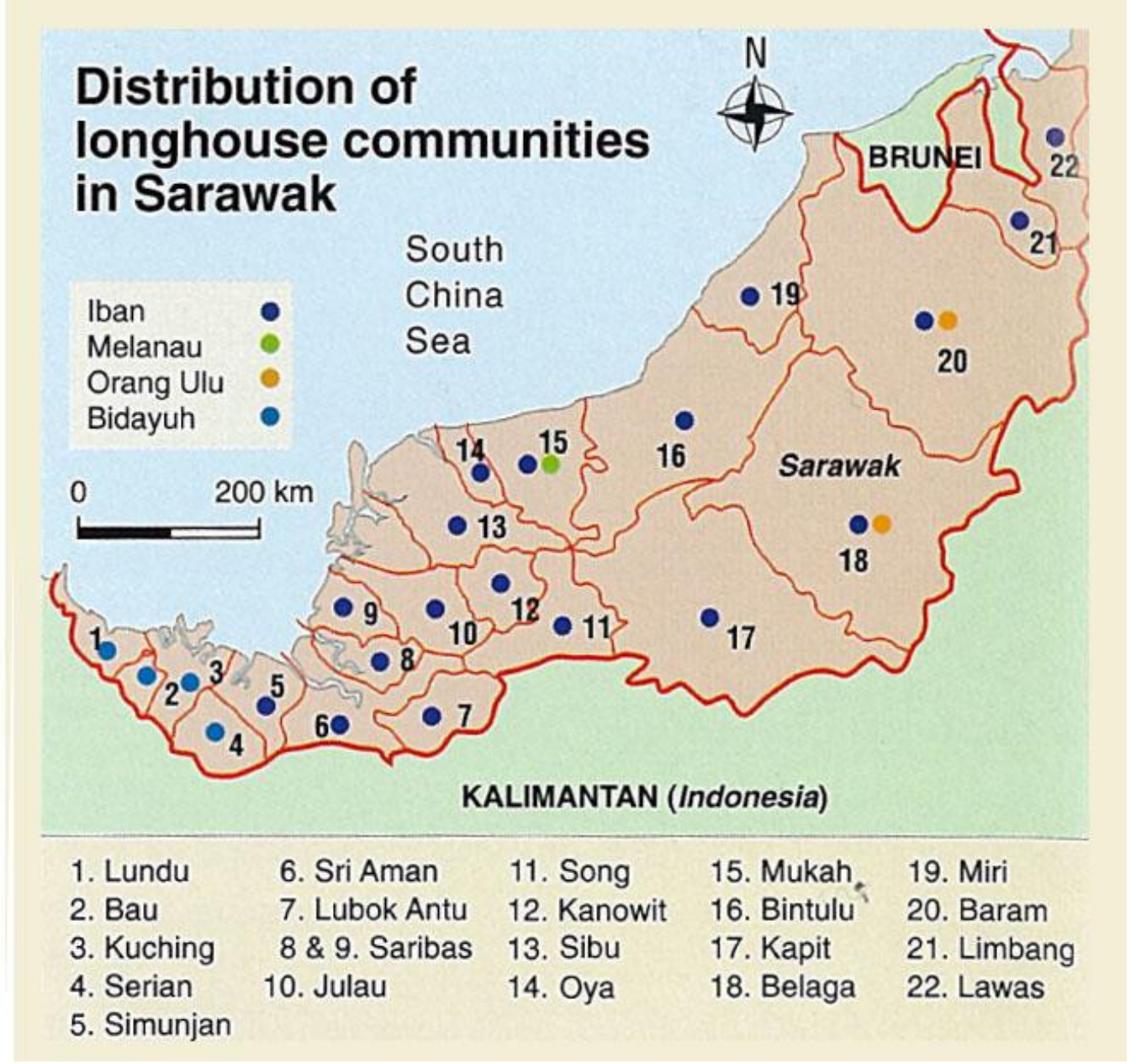

Fig. 2.1 Diagram showing the distribution of the Iban, Melanau, Orang Ulu and Bidayuh longhouses in Sarawak

\footnotetext{
${ }^{90}$ Winzeler The Architecture of Life and Death in Borneo $\mathrm{p} 53$

${ }^{91}$ Tettoni and Ong Sarawak Style p17 The thesis focuses on the houses of the four main indigenous groups in Sarawak which are the Iban, Bidayuh, Melanau and Orang Ulu, having the population in Sarawak of $29.6 \%, 8.3 \%, 5.8 \%$ and $5.4 \%$ respectively.
} 


\section{Origins of the Longhouses of the indigenous people of Sarawak}

The Longhouse is considered to be the traditional dwelling of ethnic groups such as the Iban, Melanau, Bidayuh and Orang Ulu in Sarawak, Borneo. However, this form of dwelling is also found in different parts of the world. Alexander has written that the large structures can be seen among the hill tribes of Burma, Assam and the South Sea Islands of the Pacific. ${ }^{92}$ Waterson also states that this multi-family dwelling can be found in Mentawai in Indonesia and in the highlands of Vietnam. ${ }^{93}$ This further contributes to the theory that no architecture is stagnant and pure in its origins.
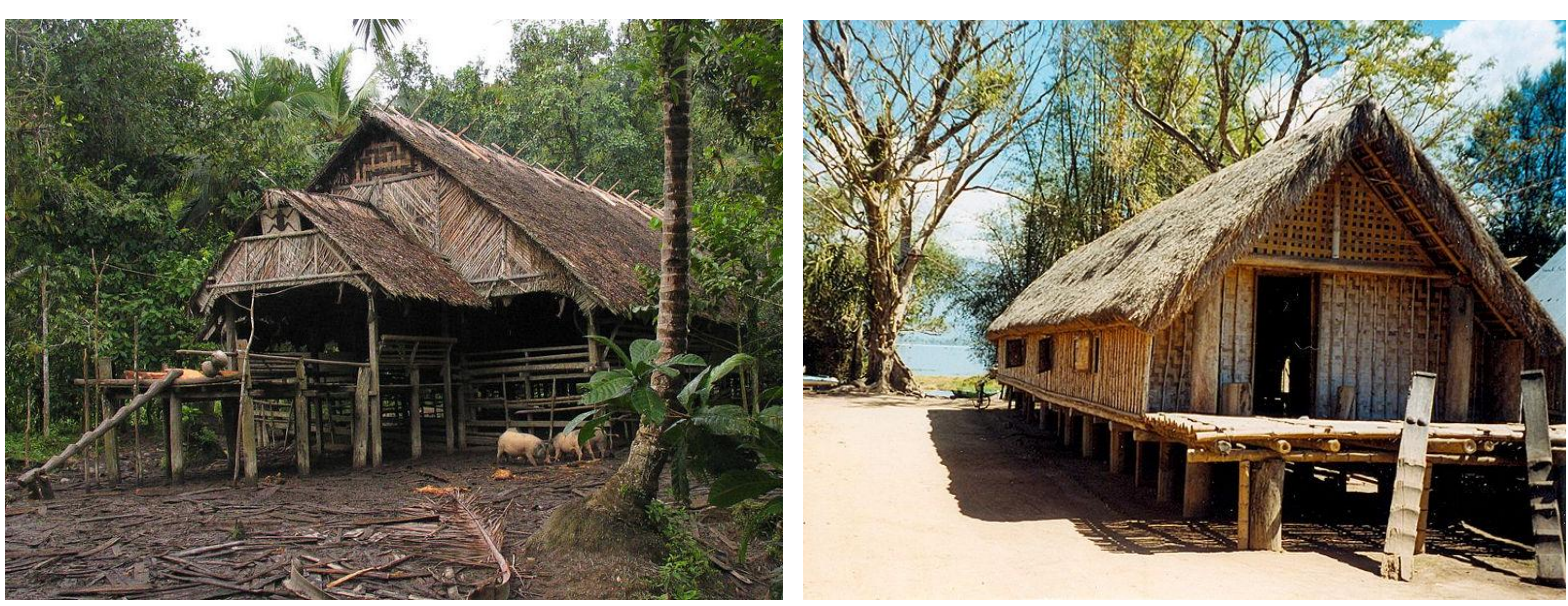

Fig.2.2 An Uma, the traditional communal house of the Mentawai in Indonesia (left) and fig. 2.3 a Mnong longhouse in the central highlands of Vietnam (right)

\section{Common Characteristics}

The houses of these groups of indigenous people look slightly different from one another. However, they all possess common physical characteristics. An average longhouse is built to accommodate as many as 40 families while some of the larger houses are built for as many as a 120 families or some 500 to 600 people. ${ }^{94}$ As the community expands, another house is constructed parallel to the first house. The lengths of the houses are expressed in terms of the number of apartments and vary from four to 50 apartments, with one apartment typically measuring four meters wide. The average length of the house is about 200 yards (180m approx) although in some cases, it may span as much

\footnotetext{
${ }_{92}$ Alexander "The Lahan Longhouse" p41

${ }^{93}$ Waterson The Living House. An Anthropology of Architecture in South-East Asia p144

${ }^{94}$ Waterson The Living House. An Anthropology of Architecture in South-East Asia p233
} 
as 400 yards ( $365 \mathrm{~m}$ approx). ${ }^{95}$ The floor width of the house ranges from 30 to 60 feet $(9-18 \mathrm{~m}$ approx). The house is raised up to six meters off the ground on timber stilts.

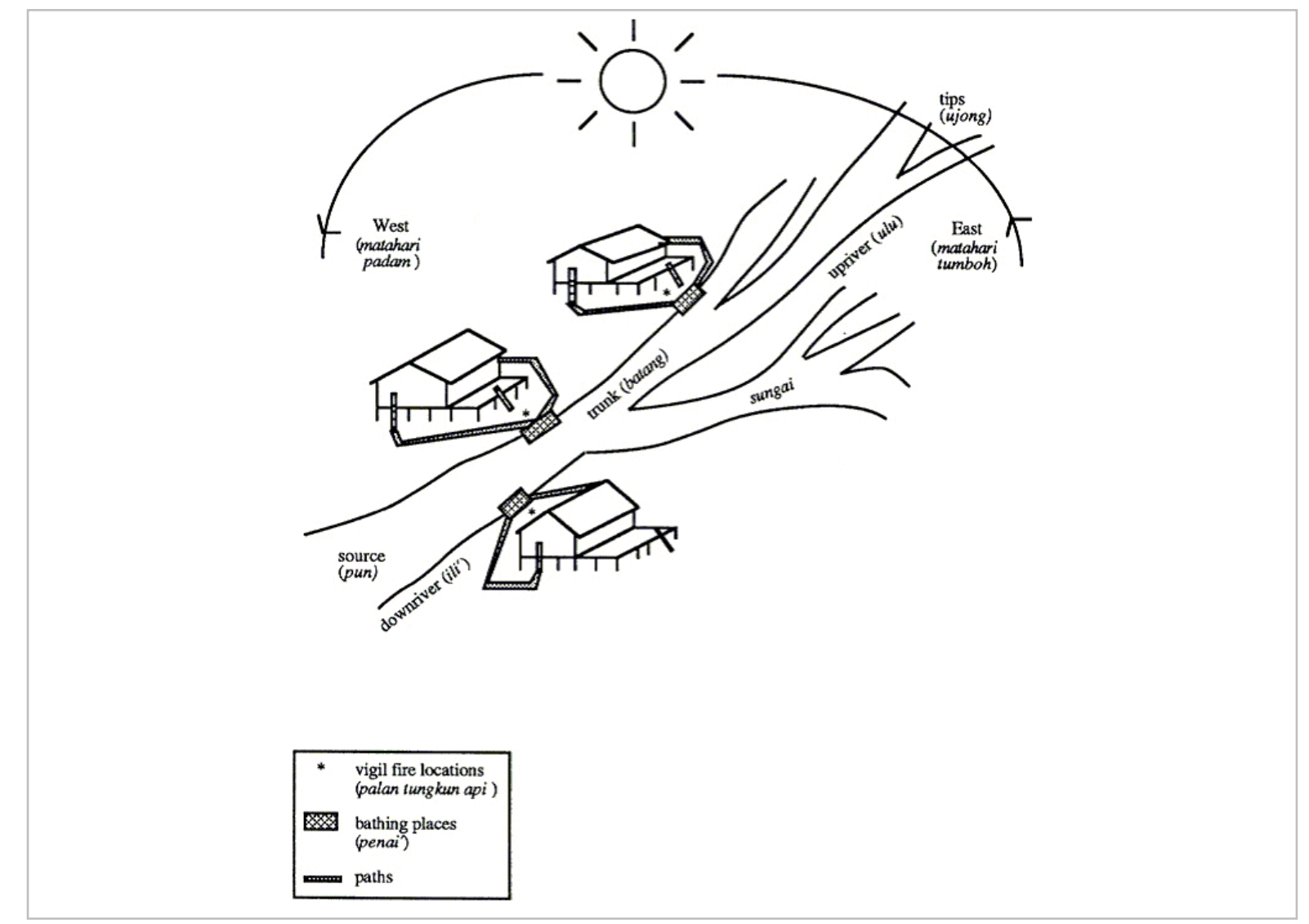

Fig. 2.4 The longhouse is usually oriented to face north-south to both face the river and the rising sun to the east

A row of family units are arranged along one side of the building (although occasionally they are built on both sides), and divided by transverse walls to form spacious chambers. Each of these chambers represents the private bilik (apartment) of a single family and is accessed from the gallery through metal hinged doors. The family inhabiting each apartment typically consists of three generations - grandparents, a son or daughter, his or her spouse and their children. The apartment is where cooking and dining takes place.

The organization of space in the longhouse is related to gender and marital status. There is a separation between unmarried men and women within the sleeping arrangements. The women have a separate room in the inner apartment or sometimes sleep in the loft. The older and unmarried sons as well as male guests, sleep in the outer or front part of the gallery. ${ }^{96}$ The men's

\footnotetext{
${ }^{95}$ Waterson The Living House. An Anthropology of Architecture in South-East Asia p234

${ }^{96}$ Winzeler The Architecture of Life and Death in Borneo p61
} 
house is also an extension of such arrangement and is a separate dwelling away from the Bidayuh longhouse. A raised platform in the men's house, around the inside perimeter of the headhouse, serves as a seating and sleeping area for the bachelors. ${ }^{97}$

Each family apartment is only separated by a wall that does not fully extend to the ceiling. People in one apartment may peek through holes or cracks to inspect their neighbours without being considered rude and banter is frequently exchanged. ${ }^{98}$ The apartments can be opened up to the ruai (public gallery) which runs the full length of the house and is unobstructed by any walls. The gallery is a communal space and is utilized differently by men and women. The women usually use the gallery for work purposes such as weaving and pounding rice while the men lounge around. However, when guests arrive at the longhouse, the gallery becomes the realm of the men. The female will retire to the inner apartments, which are for intimate visiting, cooking and female socializing. The gallery then becomes the arena of polite discussion, major rituals, feasting and more casual male drinking and conversation. ${ }^{99}$
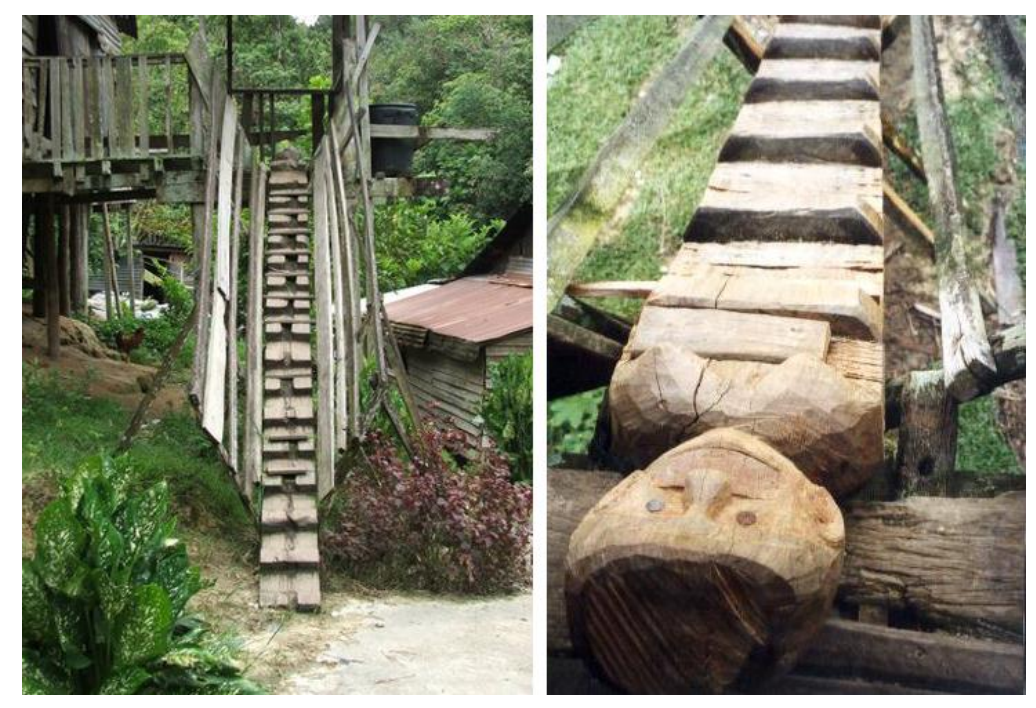

Fig. 2.5 and fig. 2.6 A face is carved at the top of the steps, believed to prevent evil spirits from entering the longhouse.

The gallery is connected to the tanju (an exposed verandah) where the laundry, fish and crops such as rice grain and pepper are left to dry. A continuous wall known as the 'dog wall' (it keeps the dogs out of the private apartments) separates the gallery from the inner apartments. ${ }^{100}$ Storage huts are located round the house. These huts are raised on piles and are used for storing grains harvested by one family. The space under the house is where the pigs and chickens forage for food or scraps that fall through the gaps in the split palm floor. The longhouse has entrances on its end and is accessed by a notched log which acts as a flight of stairs. These logs are typically carved into anthropomorphic faces or heads, believed to drive away evil spirits.

\footnotetext{
${ }^{97}$ Chen 'Architecture' The Encyclopaedia of Malaysia p35

${ }_{98}$ Winzeler The Architecture of Life and Death in Borneo p62

${ }^{99}$ Winzeler The Architecture of Life and Death in Borneo 065

${ }^{100}$ Winzeler The Architecture of Life and Death in Borneo p59
} 


\section{Types of Longhouses}

Although the longhouses of Sarawak all share common physical characteristics, there are certain attributes that differentiate these longhouses from one another. The four main types of longhouses are the Iban Longhouse, Melanau Tall House, Orang Ulu Longhouse and the Bidayuh Longhouse.

1) Iban Longhouse

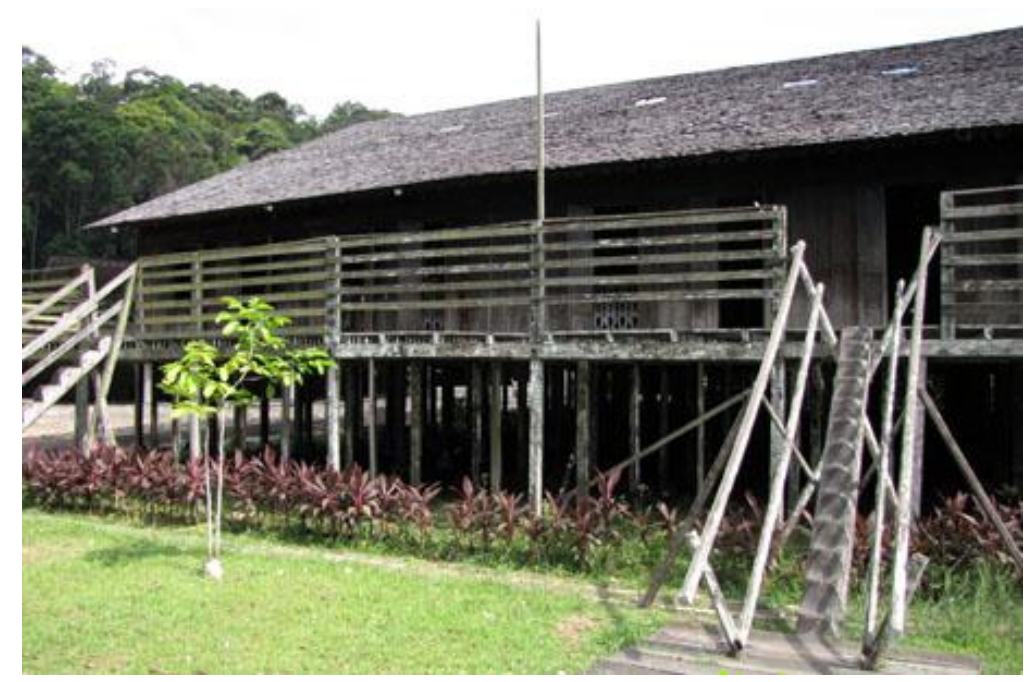

Fig. 2.7 The Iban Longhouse, Sarawak

The Iban longhouses can be found throughout the lowlands of Sarawak. The walls of the longhouse are made of tree bark and the roof either of thatch or shingles made from ironwood. ${ }^{101}$ As the community becomes more established, the longhouse will gradually improve and upgrade. The more prosperous longhouse is made of belian (ironwood) and higher grades of hardwood while the roof is being constructed with zinc sheeting or ironwood shingles. ${ }^{102}$ The principal entrance of the longhouse is its penai', a bathing place by the river. ${ }^{103}$ As the penai' is regarded as the outer threshold of the community, visitors entering the longhouse by this way must first bathe at the penai' before being welcomed into the house by their hosts.

Each apartment is divided horizontally into an lower level (the main family apartment) and upper level (sadau or loft). The more contemporary Iban longhouses have a wider and larger gallery and inner apartments to accommodate extended families. The loft is accessed from the interior of the apartment and is where bins of harvested rice are stored. Traditionally the loft was used as a sleeping place for young women of marriageable age. The loft then became associated with the ordinary domestic tasks performed by women namely, weaving and rice agriculture. Individuality and personal taste is reflected in the decoration of the living area in the inner apartments with modern pieces of furniture such as cupboards and cabinets, three-piece suites and coffee tables as

\footnotetext{
${ }^{101}$ Chen 'Architecture' The Encyclopaedia of Malaysia p35

102 Reed "Visiting Longhouses" unpaginated

${ }^{103}$ Chen 'Architecture' The Encyclopaedia of Malaysia p35
} 
well as the treatment of the room walls with carefully incised wood carving, bas-relief panelling or coloured paintwork. ${ }^{104}$

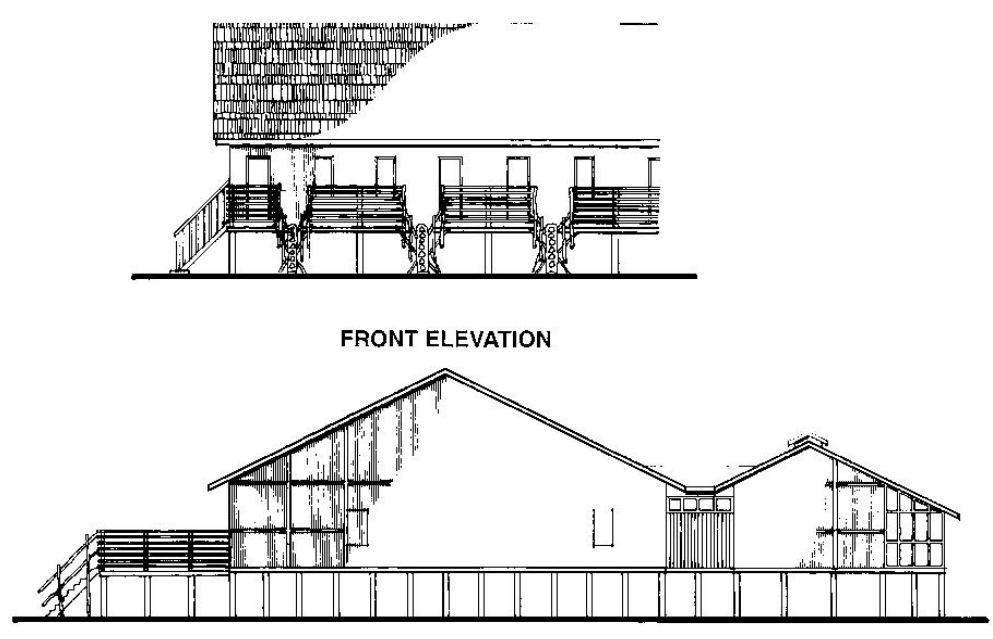

RIGHT ELEVATION

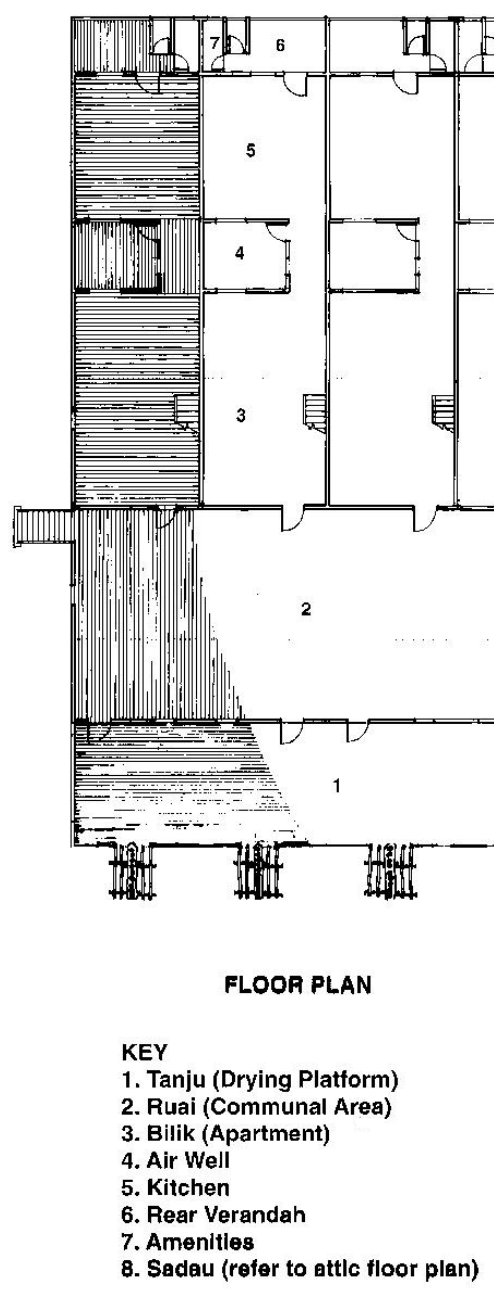

Fig. 2.8 Diagram illustrating elevations and floor plans of the Iban Longhouse

${ }^{104}$ Tettoni and Ong Sarawak Style p114 
2) Melanau Tall House

The Melanau traditional dwelling is a type of a longhouse but it is best known as the rumah tinggi (tall house) as it consists of three storeys. However, similar to the longhouse, the rumah tinggi consists of 20 to 30 apartments. The house stands sturdy as a fortress with posts made out of solid belian tree trunks. The first floor is regarded as a communal space and is where the kitchen is located. The middle space is the family area, while the top floor is where the family's valuables (such as brassware, fishing nets and tools), are kept. ${ }^{105}$ As the house was designed to provide safety from enemies and pirates, security measures included notched steps that were drawn up at night and flooring which was made out of a double layer of palms trunks, making it impenetrable to sharp weapons such as spears and knives. The walls are made of tree bark while the roof is made of palm which is readily available from the jungle.

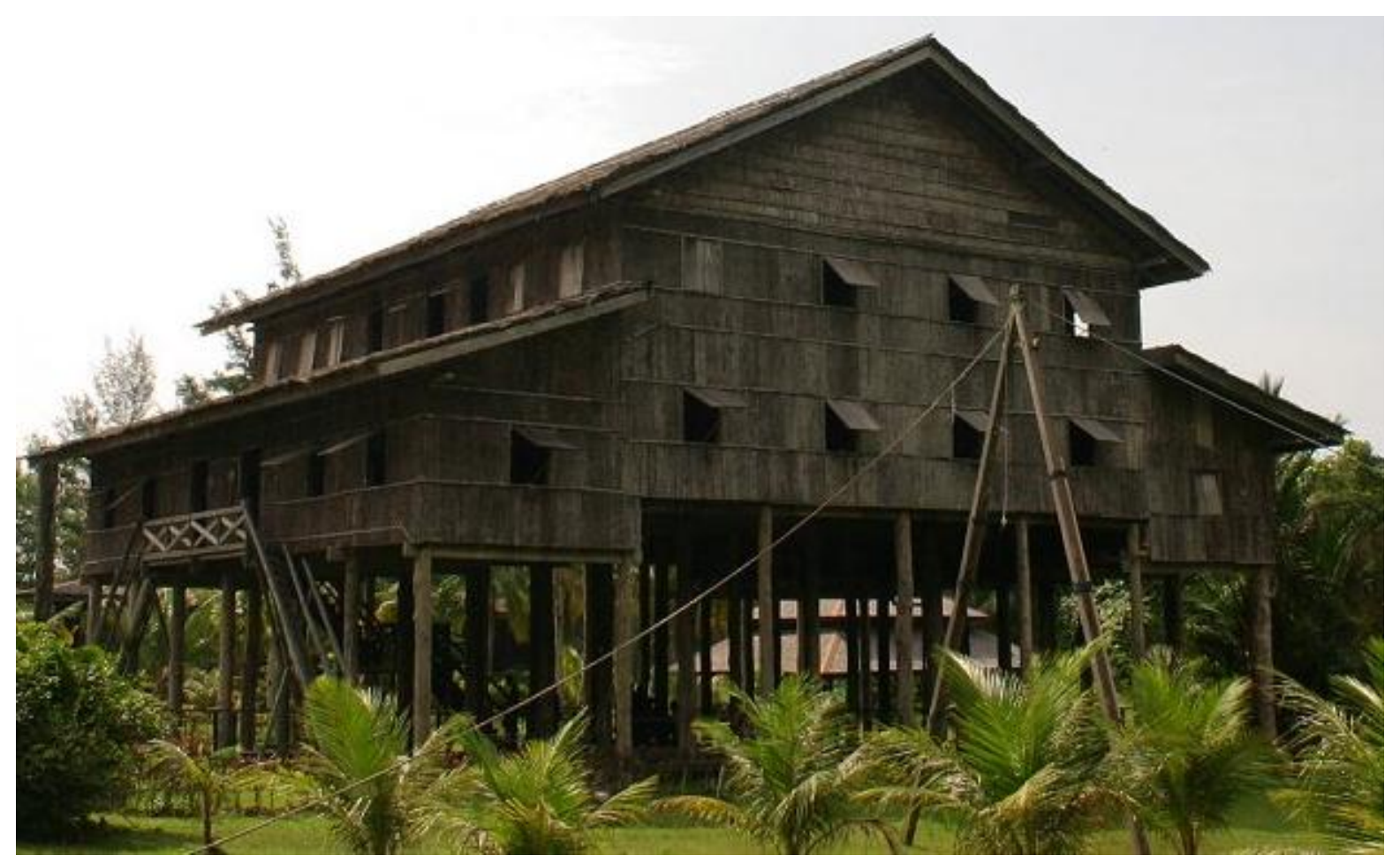

Fig. 2.9 The Melanau Tall house, Sarawak

${ }^{105}$ Chen 'Architecture' The Encyclopaedia of Malaysia p35 

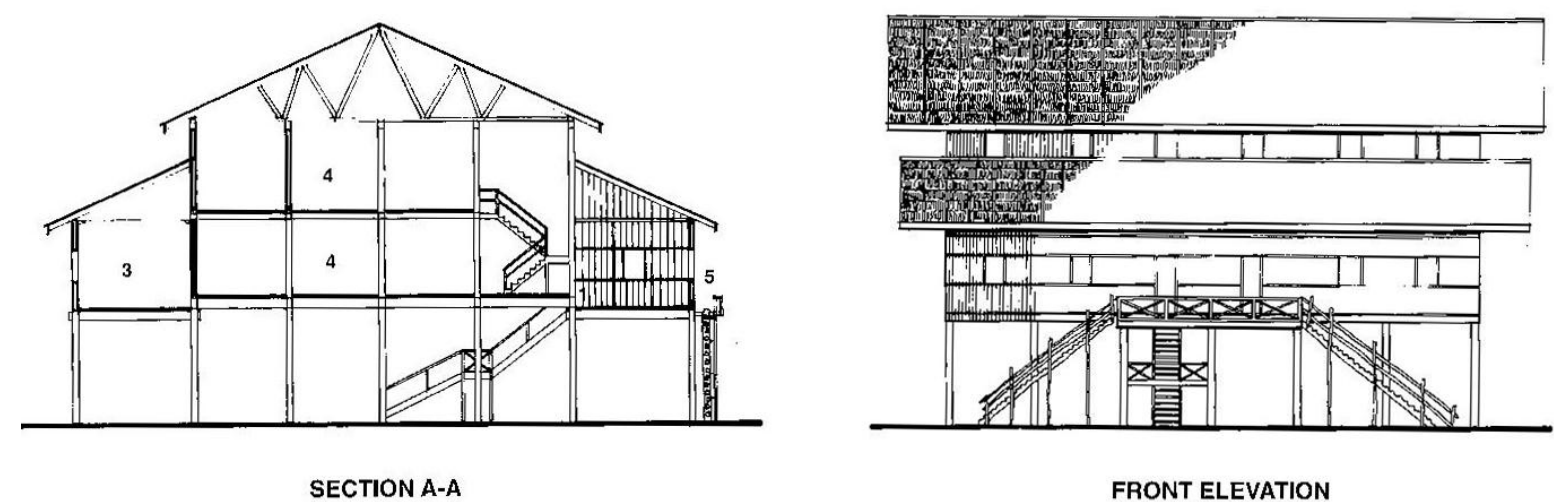

FRONT ELEVATION

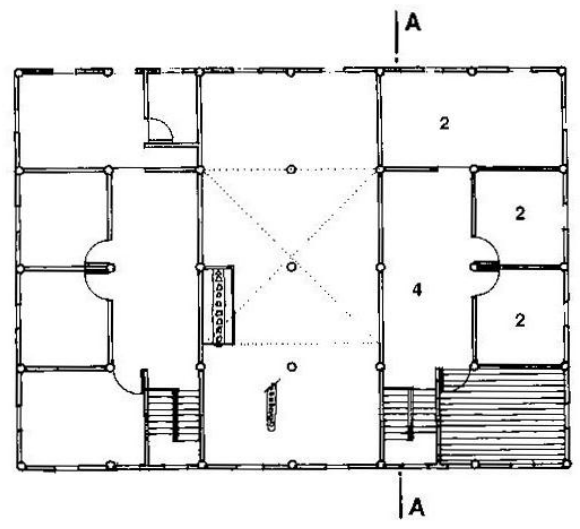

FIRST FLOOR PLAN

KEY

1. Serambi (Communal

Area)

2. Bedroom

3. Kitchen/Dining

4. Living

5. Balcony

6. Amenities

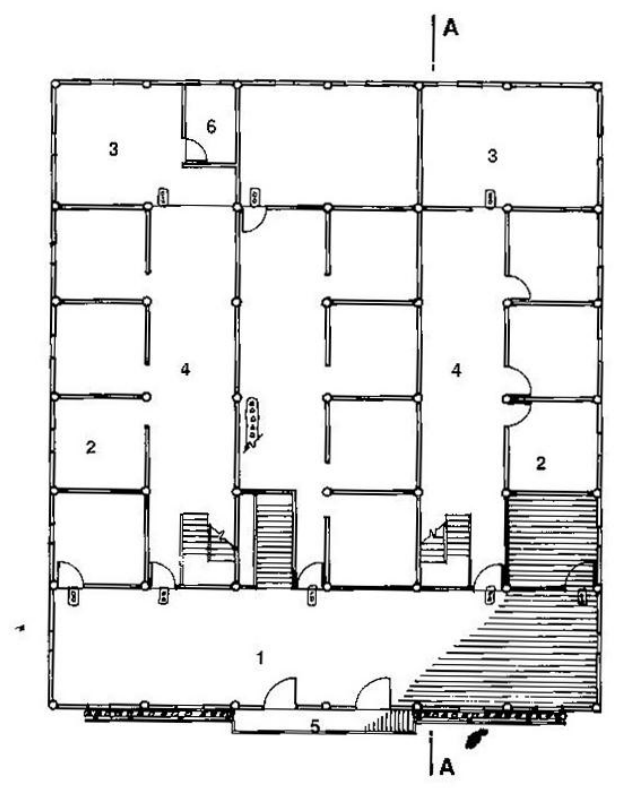

MAIN FLOOR LEVEL

Fig. 2.10 Elevations, sections and floor plans of the Melanau tall house. 


\section{3) Orang Ulu Longhouse}

The Orang Ulu longhouses are located on the uneven terrain of the interior highlands and are similar to the Iban longhouses but are frequently larger and double storied. These impressive houses are also more ornately decorated with murals, woodcarvings and intricate detailing than the houses of the Iban and Bidayuh. The Orang Ulu are a hierarchal society and the aristocratic status of the Kayan and Kenyah tuai rumahs (chiefs) are represented by larger and grander apartments which are located within the centre of the longhouse and is distinguished by its raised roof.

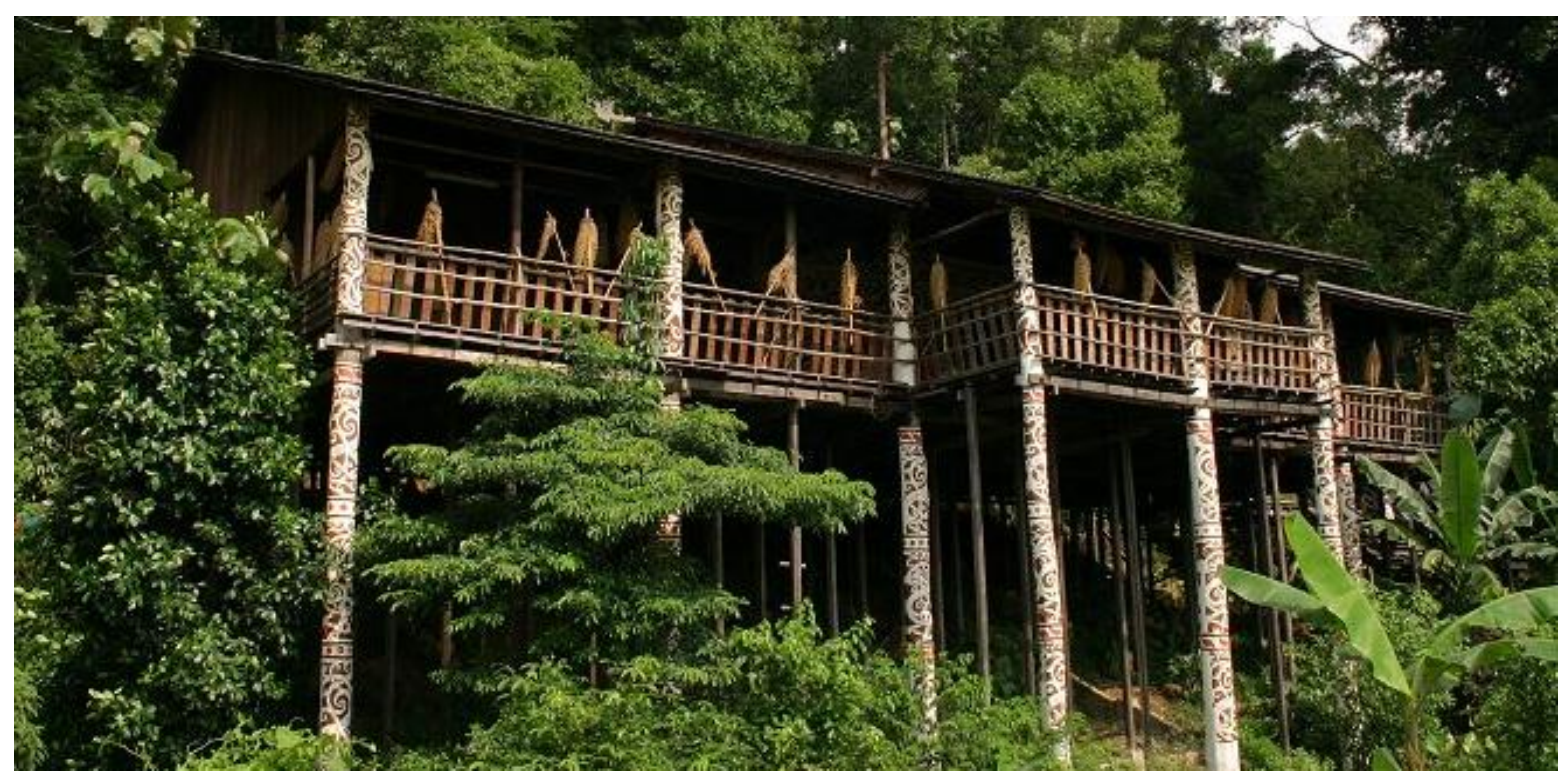

Fig. 2.11 The Orang Ulu longhouse

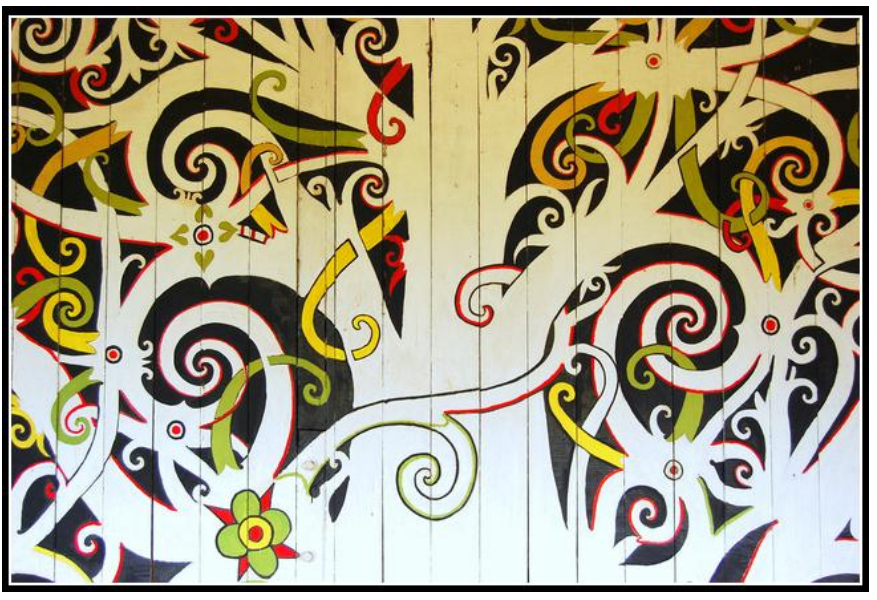

Fig. 2.12 The "Tree of Life" mural

The walls of the chief's apartments are adorned with decorative motifs of spirit figures, animals and birds as well as a "tree of life" ${ }^{106}$ mural. Traditionally, social status was determined by a person's distance from the chief's apartment thus commoners tend to live further away from the centre of the structure. ${ }^{107}$ The Orang Ulu longhouse is constructed from hard ironwood, which lasts for several generations.

\footnotetext{
${ }^{106}$ Winzeler The Architecture of Life and Death in Borneo p97 The "Tree of Life" is represented differently among the tribes but essentially the mural expresses the basic Bornean cosmological theme of sacrifice and the creation of life.

${ }^{107}$ Reed "Visiting Longhouses" unpaginated
} 


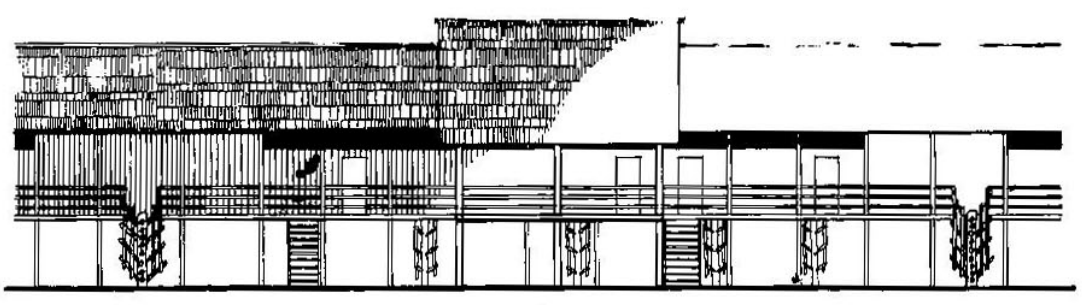

FRONT ELEVATION

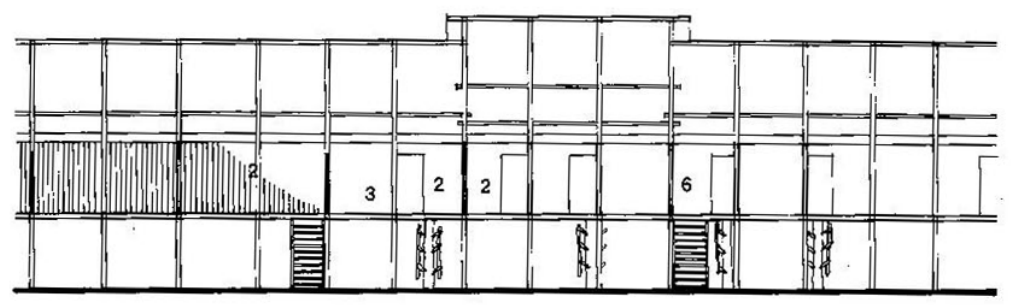

SECTION A-A

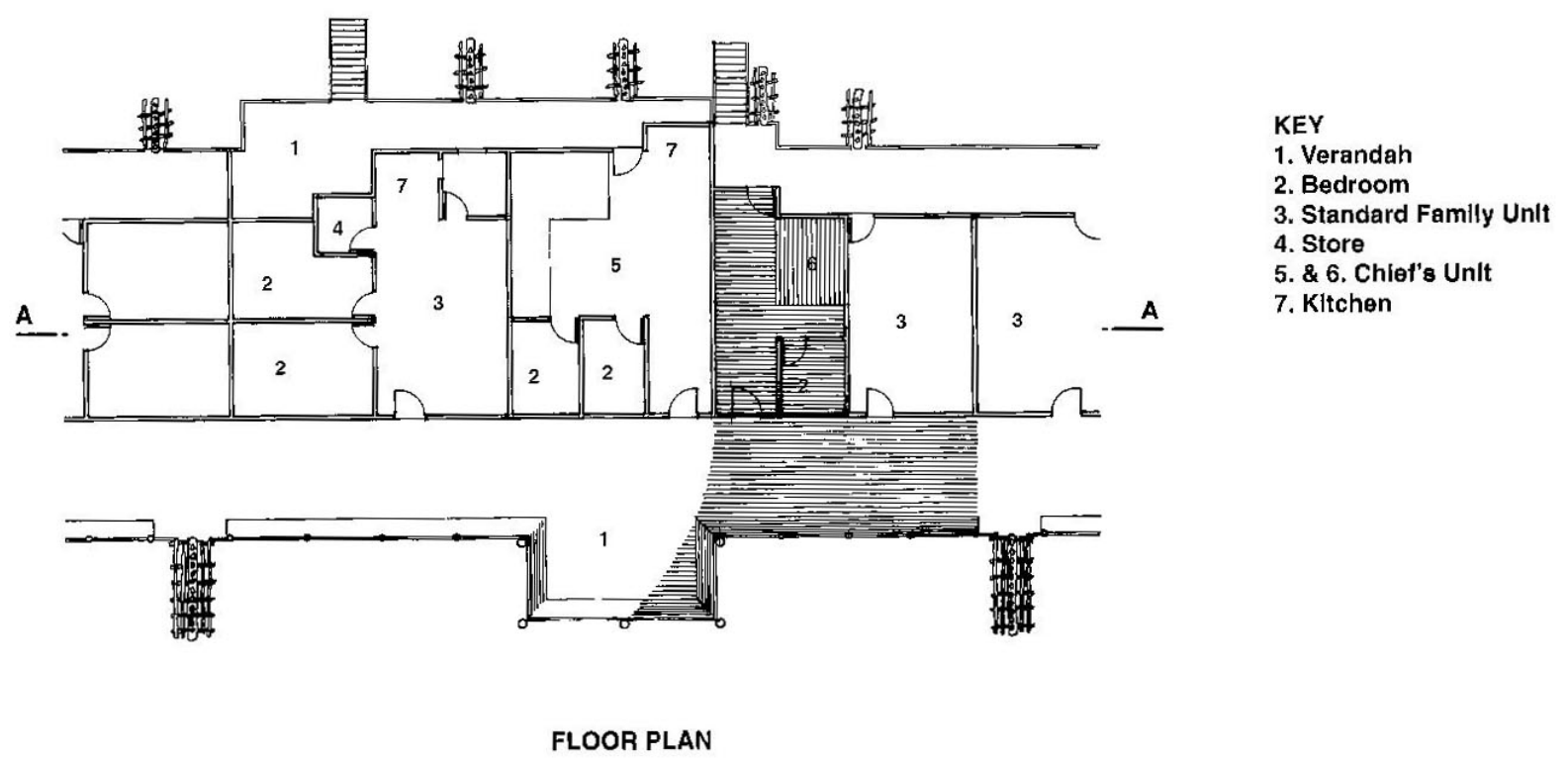

Fig. 2.13 Elevations, sections and floor plans of the Orang Ulu longhouse. 


\section{4) Bidayuh Longhouse}

As the Bidayuh were liable to attacks from other ethnic groups, the house is usually situated at the rugged foothills of remote mountains, within close proximity to roads or the river. To adapt to the uneven terrains of the foothills, the longhouse is put together as a series of terraces, gradually rising on the hillside like steps. ${ }^{108}$

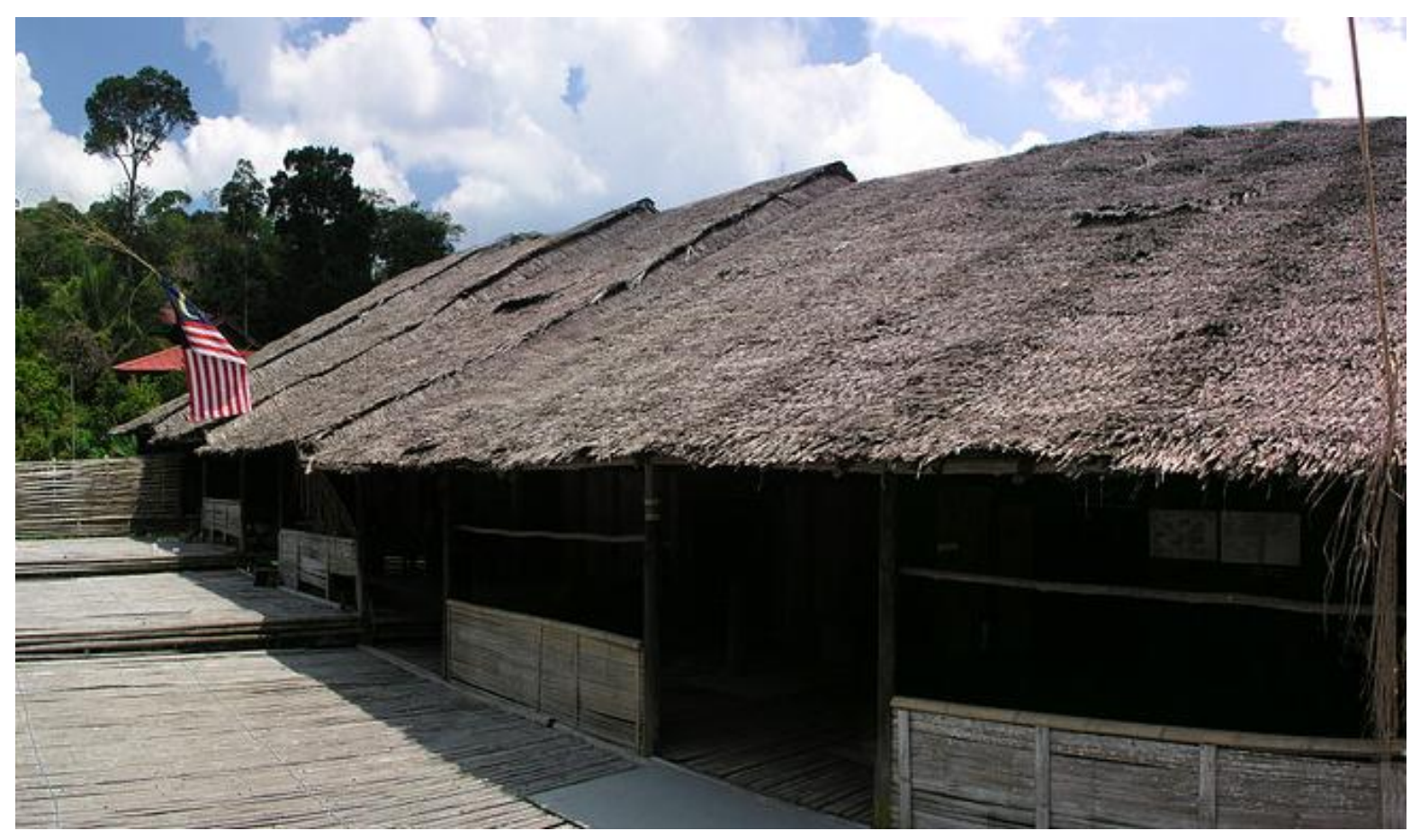

Fig. 2.14 The Bidayuh longhouse

The construction of the Bidayuh longhouse is similar to that of the Iban, but tends to be smaller and built without the external verandah. The roof and the end walls are covered with palm thatch. ${ }^{109}$ The houses use tree-trunks as posts and beams while the floor of the gallery is made out of bamboo halves. The Bidayuh frequently rely on bamboo and lighter timber as main building materials because they live in areas where bigger lumber trees are scarce and not readily available. The comparatively flimsy manner of construction means that the Bidayuh houses are less durable and do not have as long a lifespan as the Iban or Orang Ulu longhouses. Flaps are made in the roofs to allow for adequate ventilation and daylight to penetrate the dark interior family apartments. Unlike in the Iban longhouses, apartments of kin-related families are often interconnected by doorways and the corridors are narrower.

\footnotetext{
${ }^{108}$ Winzeler The Architecture of Life and Death in Borneo p114

${ }^{109}$ Tettoni and Ong Sarawak Style p107
} 

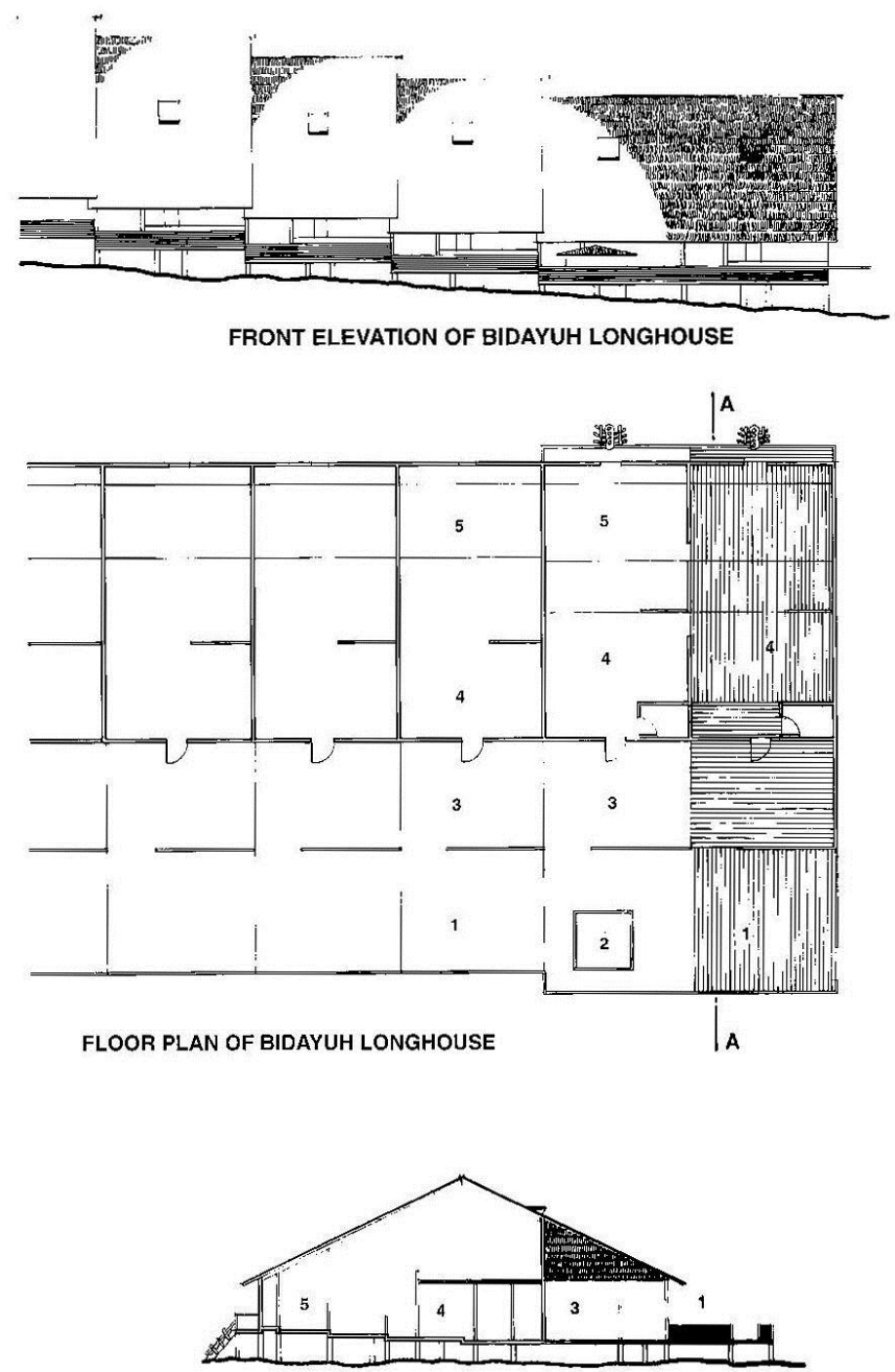

SECTION A-A

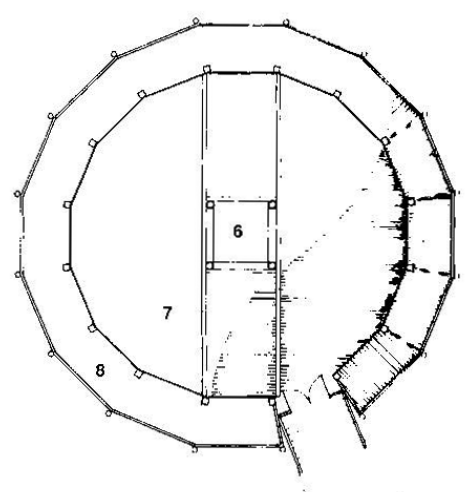

FLOOR PLAN OF BARUK

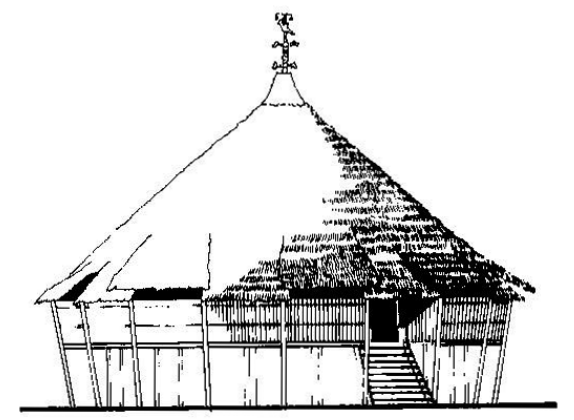

FRONT ELEVATION OF BARUK

KEY

1. Gladak (Open Deck)

2. Padl Drying 8had

3. Awak (Communal Qallary)

4. Cooking \& Dining

5. Padung (Reating Area)

6. FIreplace

7. Ceremonlal Area

8. Raised Platform

Fig. 2.15 Front elevation, floor plans and sections of the Bidayuh longhouse and front elevations and floor plans of the baruk (head house) 


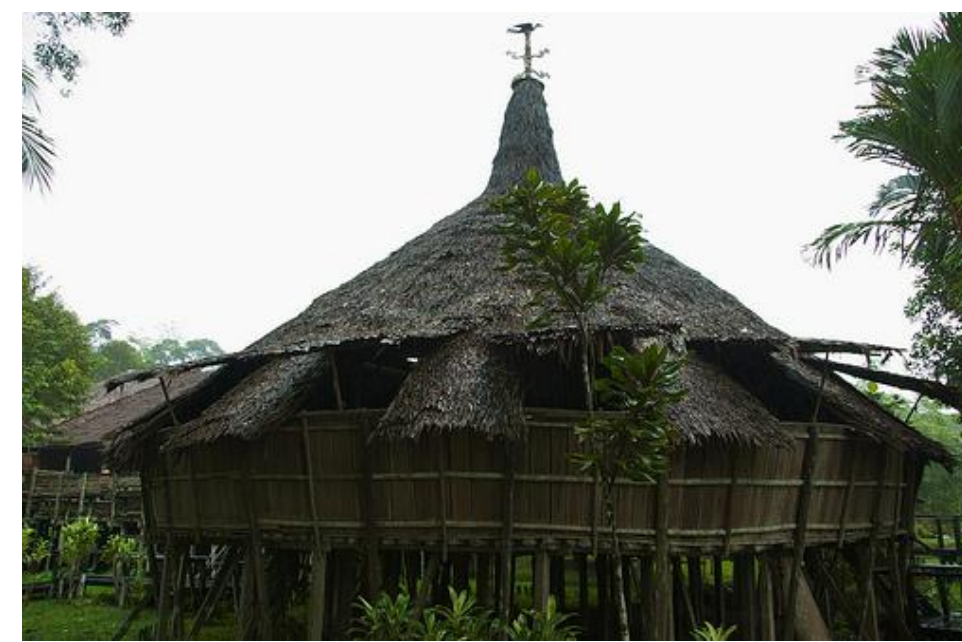

Fig. 2.16 The baruk or men's head house

Bidayuh domestic architecture also includes a separate dwelling for men commonly referred to as the baruk (head house). These houses are also known as men's houses and are normally described as round or octagonal with a conical roof although square or irregular ones

were also noted. ${ }^{110}$ As the name suggests, the house is traditionally the customary residence of the unmarried male adolescents, men of the village and male guests to the village. The use of the men's house was then reduced to a repository for the collection of skulls and for holding community meetings, rituals and ceremonies. The structure is supported by an elaborate framing system bounded by rattan and ropes made from tree bark. The floor is constructed of a double layer of split bamboo, impenetrable to attacks from below.

\section{Rebuilding and Abandoning the Longhouse}

The organic material of the longhouse will inevitably undergo the consequences of rapid decay, especially in the hot, rainy and humid equatorial climate of Borneo. Although traditional builders were concerned about deterioration and insect attacks, they did not apply preservatives and protective finishes on the buildings. The builders, however, did engage in various practices and adhere to certain beliefs to ensure the longevity of their building. Bamboo and wood used in the construction of houses are believed to last longer if soaked in water for several weeks. ${ }^{111}$ The Bidayuh believed it was unsuitable for trees to be lumbered during the phase of a full moon. At this time, the moon is considered to be 'soft and crumbly', reflecting the condition of the wood. It was also considered not ideal to cut timber during periods of low tide as the trees would have absorbed the remaining water of the sea and would be weaker and prone to rapid deterioration. ${ }^{112}$

Longhouses can also simply be the victims of unfortunate accidents and natural disasters. Fires are a common catastrophe. As the longhouse is made entirely of flammable material, fires are difficult to

\footnotetext{
${ }^{110}$ Winzeler The Architecture of Life and Death in Borneo p49

${ }^{111}$ Winzeler The Architecture of Life and Death in Borneo p30

${ }^{112}$ Winzeler The Architecture of Life and Death in Borneo p30
} 
contain and capable of devouring the structure quickly and relentlessly. Longhouses are also liable to be destroyed by floods especially during the rainy monsoon seasons. The houses can be swept away by the strong currents as the water rises in the nearby river.

When the longhouses are destroyed or deteriorate, the community is forced to rebuild their homes. Longhouses are also rebuilt in different locations when there is an epidemic and illness in the village, crop failures or other misfortunes that are viewed as evidence of spiritual decline. ${ }^{113}$ If a house is ruined by fire, no part of the materials of the old house is used in the construction of the new, for fear of the new house rendering the same ill-fate.

The abandonment of the longhouse may be partial, complete, abrupt or gradual. The abrupt abandonment of the longhouse may be caused by houses not being rebuilt after being destroyed in a fire or may be the result of government demand or persuasion. The villagers may desert the longhouse gradually as newer families build individual houses elsewhere. Although many people have migrated to work in the cities and towns, they still maintain strong bonds with their ancestral longhouses and return during public holidays and festivals. ${ }^{114}$ The Melanau started shifting out of their indigenous houses as early as the nineteenth century. The shift is complete, resulting in very few tall houses remaining presently.

An example of how Malaysian vernacular architecture engaged with ideas of power and status is apparent in the Malay house and longhouses of Sarawak, which of course operated to support both domestic and communal purposes. The houses were important symbols of social status and power. Status is a contested domain, and the symbolic elaboration of houses has been an important element of this contest. ${ }^{115}$ Through architectural design, decoration and planning, houses symbolically express their purpose and the pertinent characteristics of their inhabitants. ${ }^{116}$ There are numerous ways in which Malaysian vernacular architecture indicates status and prosperity. The key themes are size and location, modern and imported materials, craft and material possessions and furniture.

\footnotetext{
${ }^{113}$ Winzeler The Architecture of Life and Death in Borneo p55

${ }^{114}$ Winzeler The Architecture of Life and Death in Borneo p130

115 London The House in Southeast Asia p24.

116 London The House in Southeast Asia p16
} 


\section{1) Size and Location}

One of the most conspicuous ways of indicating superiority is through scale. When a Malay household enjoys an increase in prosperity, they may opt to expand their house. These extensions follow an addition system.

In the Bidayuh household, there is a dwelling for men, which is separate from the main longhouse. It is known as the baruk (men's house or head house). The name itself assumes the connection between men and authority. In comparison to the longhouse, the baruk is huge in scale and takes on a different shape (octagonal). The baruk is where young men and bachelors reside and where community meetings, rituals and ceremonies take place. In the centre of the room was the hearth where the head trophies ${ }^{117}$ are placed. The emphasis on size and ornamentation (or in this case, the collection of skulls) parallels a social arrangement that relies on prestige and influence for leadership. ${ }^{118}$

Size is also a strategy used to assert dominance. In hierarchal societies, such as the indigenous tribes of the Kayan and the Kenyah, the aristocratic status of chiefs is represented by significantly larger apartments and higher roofs. Social status was determined by a person's distance from the chief's apartment which is located within the centre of the longhouse, thus commoners tend to live further away from the centre of the structure. ${ }^{119}$

\section{2) Modern and Imported Materials}

Perceptions of architecture started to change after the 1950 s. $^{120}$ It became an ongoing trend in Southeast Asia for people to demonstrate their wealth by employing materials and styles that were thought to portray modernity. Western-styled house forms and building materials have been glorified, posing a threat to the survival of wooden houses. The use of traditional building materials, such as wood and bamboo, are considered to be outdated and symbolising a low status. This is a similar case to mud which is thought of in the same way, although it serves as a main building material for shelters for more than half the population in developing countries across Asia, Africa and America.

\footnotetext{
${ }^{117}$ Tettoni and Ong Sarawak Style p13

Headhunting was a spiritual excursion and the skulls hanging in the longhouse serves as trophies won during battles fought against marauding pirates and dissenting war faring tribes along the river systems.

${ }^{118}$ Crouch and Johnson Traditions in Architecture p105

${ }^{119}$ Reed "Visiting Longhouses" unpaginated

${ }^{120}$ Ismail Houses in Malaysia. Fusion of the East and the West p43
} 
Modern materials, however aesthetically and functionally unsuitable, are desired because of their purchase cost and durability. For example, zinc or asbestos-cement sheets are commonly used to replace thatched roofs of the Malay house. ${ }^{121}$ Zinc is inappropriate as it possesses high thermal conductivity, creating sweltering hot interiors during the day and chilly interiors at night. Heavy downpours produce deafening clatters on a zinc roof but this was to be tolerated.

Highly decorated wooden structures on piles are increasingly being replaced by houses built of brick and mortar. ${ }^{122}$ For Rapoport, the entire modern movement can be seen as an attack on users' meanings; the attack on ornaments, on 'whatnots' in dwellings and 'thingamabobs' in the garden, as well as the process of incorporating these elements into the environment . ${ }^{123}$

Like the Malays, the more modern dwellings of the indigenous Bidayuh people reflect Western urban influences and vary in both materials and design. There are wooden houses and there are brick or concrete block and stucco houses, or a combination of the two materials. Cost and prestige is a significant factor in the decision to build in wood, brick or block stucco. An affluent village dweller will build in a modern-style stucco house; those less well off will also be influenced by the relative cost of materials as well as the greater prestige, and, it is believed, the durability of brick and cement block. ${ }^{124}$

3) Craft

One of the magnificent features of some colonial buildings is the displays of intricate detailing, the efforts of skilled craftspeople. The economic standards of the Malay house owner were also reflected in the attention to the detail and decoration of their houses. The richer they were, the more elaborate the wooden carvings and other detailing. ${ }^{125}$ The use of fine details required the skills and artistry of craftsmen which were expensive and only afforded by people with a high income.

4) Material Possessions and Furniture

In the past, the concept of life among Malay society was not based on ostentatious living or the need to strive for excessive possessions. A common characteristic of the traditional Malay house is its bareness and lack of furniture, relying on the rudimentary and functional nature of

\footnotetext{
${ }^{121}$ Lim The Malay House. Rediscovering Malaysia's Indigenous Shelter System p134

122 London The House in Southeast Asia p24.

${ }^{123}$ Waterson The Living House. An Anthropology of Architecture in South-East Asia xvi

${ }^{124}$ Winzeler The Architecture of Life and Death in Borneo p119

${ }^{125}$ Ismail Houses in Malaysia. Fusion of the East and the West p43
} 
the house and its fittings. There has been a tendency towards floor living: sitting on the floor to eat, talk and entertain. ${ }^{126}$ As Waterson has noted:

Winstedt (1909) evocatively wrote on his account of the Malay house and observed that the feature that strikes the casual observer on entering a Malay house is the absence of what the European conceives to be furniture; and should he be interested further and discover that the words for "chair" and "book rest" are Arabic, the words for "towel", "table" and "cupboard" Portuguese, the words for "curtain", "bedstead" and "box" Tamil, then he will certainly imagine that there is no such thing as native Malay furniture. ${ }^{127}$

Malay households have gradually absorbed modern consumer culture and the present day adoption of Western-style furnishing and equipment in the interior is considered to be evidence of a household's prosperity.

\section{Chapter Conclusion}

The tradition of longhouse dwelling is a multi family living arrangement historically favoured among the tribes in Sarawak. People relied on this living arrangement for protection from other tribal attacks and for support in order to survive the harsh environment. In the village compound, there are no markers to demarcate external territories.

It may seem that there is a lack of regard towards privacy within the confinement of the single roof structure. Distinctions between public and private domains as well as the understanding of what activities take place in the spaces during specific times of the day and night are marked through behavior and mutual understanding among the inhabitants. The organization of time, space and people relates to deeper concepts of social value concerning gender, age and status as well as more abstract values of privacy and community. ${ }^{128}$

Just like the houses of the Malays, status and hierarchy in the village is expressed in conventional ways such as in the increase in size and ornamentation, the adoption of material possessions and furniture, and the replacement of traditional building materials with modern materials. The aristocratic status of the tuai rumahs (chiefs) in the Orang Ulu longhouse are represented by larger and grander apartments which are located within the centre of the longhouse and is distinguished

\footnotetext{
${ }^{126}$ Waller and Bradbury Fusion Interiors p61

${ }^{127}$ Waterson The Living House. An Anthropology of Architecture in South-East Asia p223

${ }^{128}$ Encyclopedia of Vernacular Architecture of the World p72
} 
by its raised roof and the display of decorative murals. It is only in the Bidayuh longhouse that hierarchical differences are shown as a separate dwelling. The baruk, a congregation space for important village meetings, rituals and ceremonies, is significantly different in shape and size. It also houses a repository for the collection of skulls, which serves as trophies of war and displays of leadership and prestige.

Cultural conventions also demarcate gender spaces. The intimate interior spaces of the longhouse, such as the kitchen, loft and inner apartment, are occupied by the women while the outer spaces, such as the front part of the gallery, becomes the male domain. In the Bidayuh longhouse, the men's house, as implied by its name, is also just exclusive to men.

The longhouses of Sarawak are not pure in its origins but are the product of many generations of cultural exchanges. It derives from a firm understanding of local climatic and environmental conditions to establish itself as 'Malaysian vernacular architecture'. 


\section{Chapter 3: Foreign Influenced Architecture Part 1 (1511-1957)}

Malaysia's complex architectural heritage is the result of centuries of interaction with numerous cultures. To understand the development of vernacular architecture in Malaysia, it is important to be conscious of the historic events that occurred in the country. The Chinese immigrants and the Portuguese, Dutch and British rulers brought with them their homeland traditions which were reflected in their administrative buildings and domestic architecture. The chapter questions the definition of vernacular by analyzing the architectural strategies adopted by these foreigners in producing hybrid architecture.

Paul Oliver states that cross cultural exchanges can only take place between two cultures which share enough common ground. ${ }^{129}$ The chapter investigates this theory by making cross sectional comparisons to identify the vernacular parallels of building types introduced by the colonial rulers and the Chinese immigrants to the country. The chapter will also question the definition of vernacular by analyzing the architectural strategies adopted by these foreigners in producing hybrid architecture.

\section{Architecture of the Immigrants - The Chinese Community}

The Chinese are considered to be one of the major immigrant groups in Malaysia. When shopkeepers, craftsmen and farmers from Southern China permanently settled in Melaka in the seventeenth century, they brought with them a new style known as the Straits Eclectic style, which is the fusion of Chinese, European and Malay architectural styles. The Chinese maintained many of their own homeland traditions as is reflected in their domestic architecture evident throughout Malaysia. Chinese architecture can be classified into three groups: residential (such as traditional shophouse and the townhouse), religious (such as the Buddhist temple), and public (such as clan or association building). ${ }^{130}$

\section{Residential}

1) The Chinese Shophouse

The Chinese shophouse is one of Malaysia's vernacular architectural buildings. This urban building type emerged with the influx of Chinese immigrants. ${ }^{131}$ The construction techniques were Chinese influenced but based on locally available materials.

\footnotetext{
${ }^{129}$ Encyclopedia of Vernacular Architecture of the World p72

${ }_{130}$ Ahmad "Southern Chinese Architecture" unpaginated

${ }^{131}$ Chen 'Architecture' The Encyclopaedia of Malaysia p90
} 


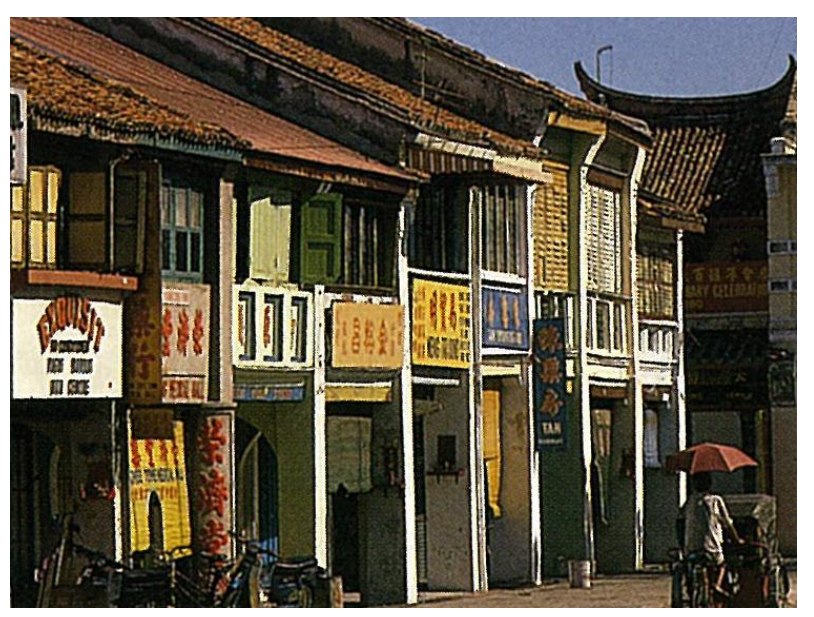

Fig. 3.1 A row of early timber shophouses in Penang.

The pre-war shophouses were basic in their construction and were made out of wooden posts supporting an attap roof. They were usually six to seven meters wide, thirty meters deep and built in rows with uniform facades and were exposed to the street where the shop's wares were displayed. ${ }^{132}$ As the name suggests, the shophouse accommodates both the residential and economic activities of a family. The earlier shophouses were single storied with the commercial area in the front and the living area at the rear.

In the 1880s, building regulations dictated that buildings had to be constructed in durable materials such as brick and tiles. ${ }^{133}$ The 'five foot way' ruling was also imposed by the British colonial administration, specifying that all shophouses had to include a minimum five foot wide verandah on the ground floor. ${ }^{134}$ This was to shelter the arcade from the extremities of the sun and rain as well as to ensure that the ground floor was pedestrian friendly. With the implementation of such regulations, combined with Western design principles, the shophouse eventually developed into two storeys. The business area was located in the front section of the shophouse on the ground floor, while the living areas were situated at the upper storey of the house and were often partitioned into cubicles and sublet to tenants. ${ }^{135}$ There is a central airwell that functions as an internal courtyard which helps ventilate the houses and allows light to penetrate the rear sections of the shophouse.

Although its origins can be traced from the southern coastal provinces of China, the shophouse gradually transformed to include European architectural traditions and to adhere to foreign regulations. The Chinese characteristics such as curved gable ends, glazed ornamental tiles and stucco decoration gave way to European features such as Venetian arches, pediments, festoons and consoles. ${ }^{136}$ The nouveau riche from developing Malaysian towns and treaty ports of Southern China found European architecture appealing hence the emergence of various stylistic interpretations of the shophouse.

\footnotetext{
${ }^{132}$ Chen 'Architecture' The Encyclopaedia of Malaysia p90

${ }^{133}$ Yeang The Architecture of Malaysia p134

${ }^{134}$ Chen 'Architecture' The Encyclopaedia of Malaysia p91

${ }^{135}$ Chen 'Architecture' The Encyclopaedia of Malaysia p91

${ }^{136}$ Yeang The Architecture of Malaysia p135
} 


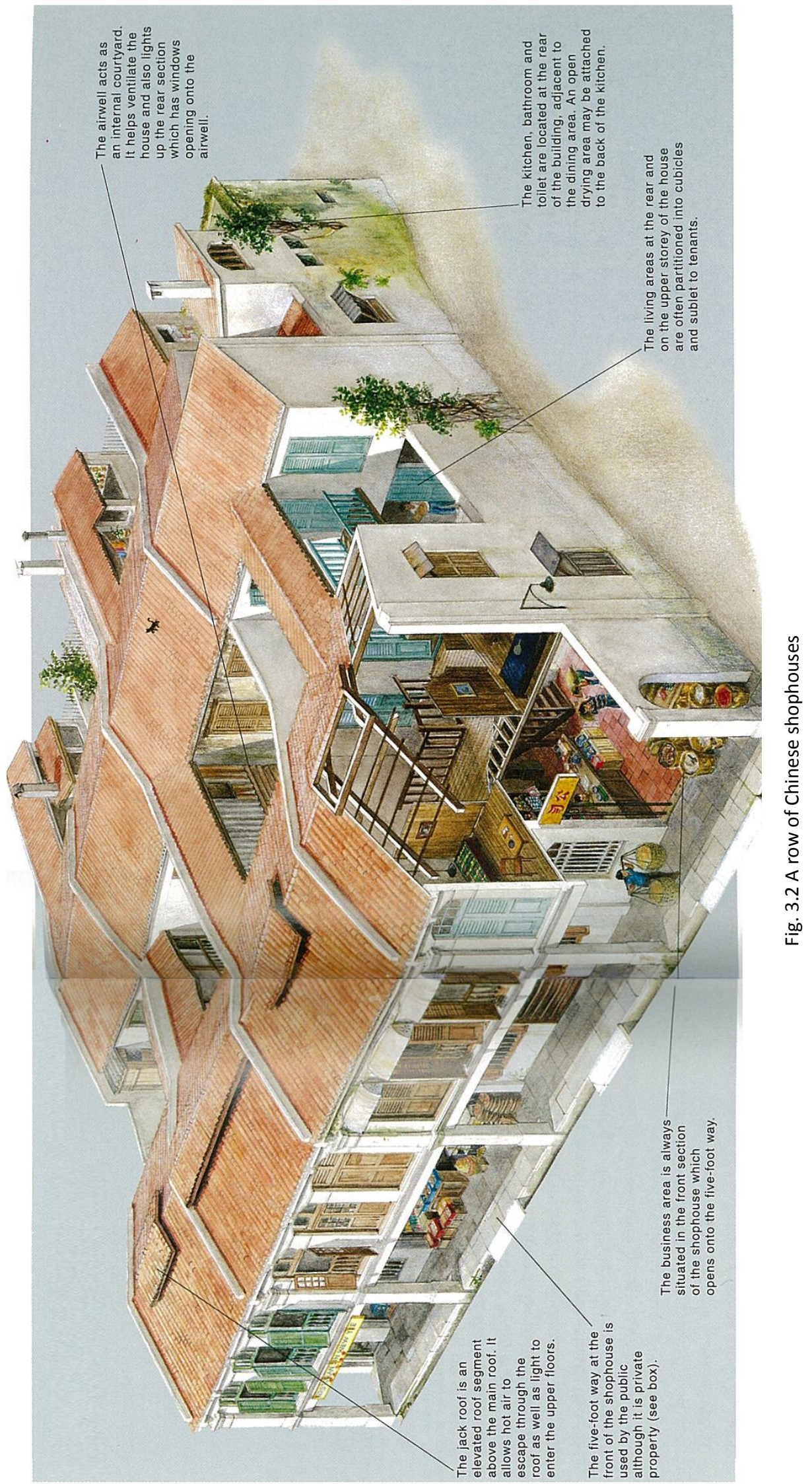




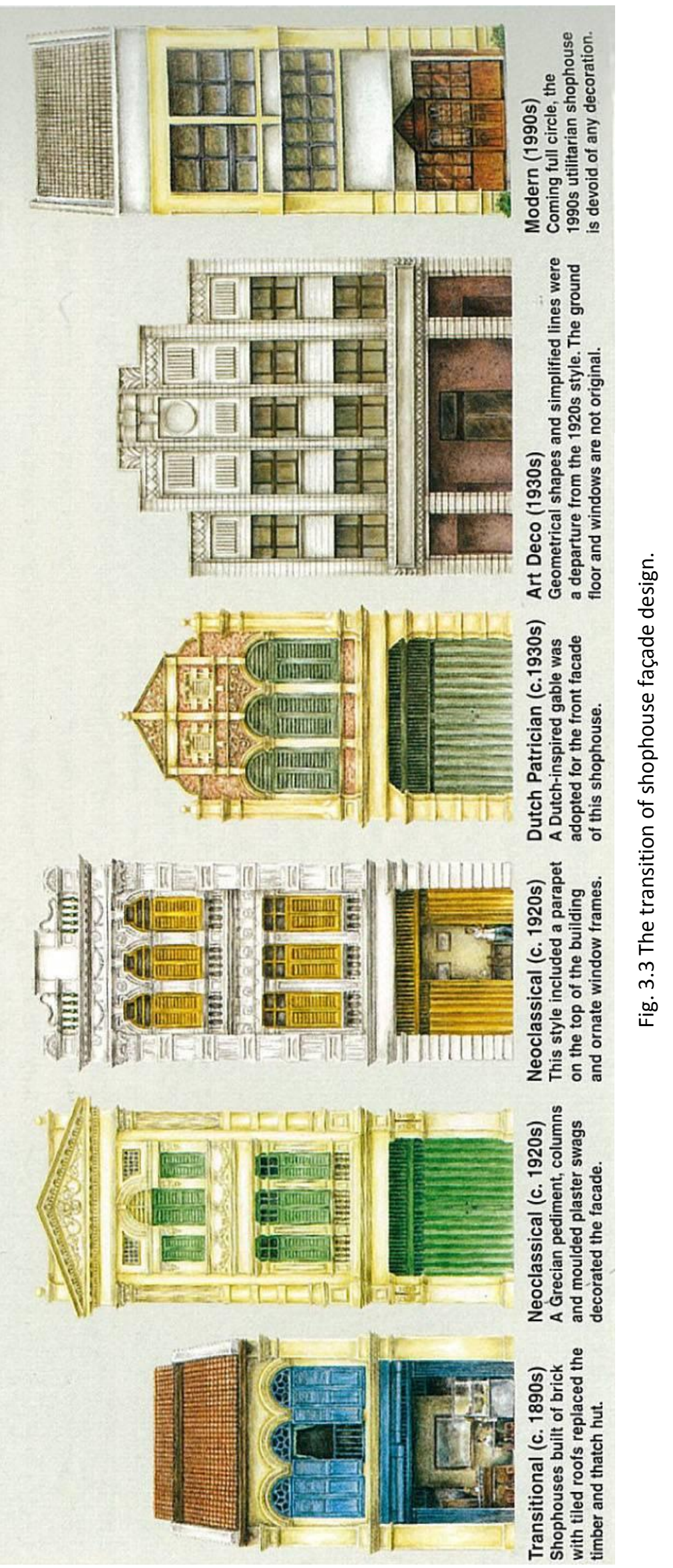


The styles of the shophouses have been categorized into three principal varieties by Ho, Hasan, and Noordin (fig. 3.3): Utilitarian or Transitional (1880s-1900s), Neo Classical (1900s-1930s) and Art Deco (1930s-1940s). ${ }^{137}$ The Utilitarian style consists of heavy pillars that supported large single wooden beams. There was minimal decoration and the first floor had a single opening that was covered with simple wooden shutters. The Neo Classical shophouses were normally three storeys high with more elaborate facades of Neo-gothic, Baroque, Palladian or Renaissance designs, which featured parapets, open balustrades and flamboyant gables. ${ }^{138}$ The windows were framed by Classical columns with foliated capitals while the fanlights above the shutters were decorated with Malay inspired carved grilles or Venetian glass. ${ }^{139}$ The shophouse was then integrated into a single block facade by the use of horizontal cornices, string courses, colonnades and arcades that provided a regular rhythm on both lower and upper storeys. ${ }^{140}$

During the late nineteenth and twentieth century, prosperous owners started to build taller shophouses with stucco figures, ceramic decorations, and glass added to the front composition of shutter and grill. ${ }^{141}$ The structural pilasters at the front walkway also grew in height and more decorative plasterwork appeared.

2) The townhouse

The townhouse, also sometimes refer to as the rowhouse, is a style of medium-density housing which is a variation of the shophouse and is similar in its construction, detailing and ventilation. ${ }^{142}$ The townhouse was the prototype house of the urban Chinese from the seventeenth century. These urban buildings were constructed with brick, plaster, concrete and timber as the major building materials.

The typical Melakan townhouses (fig. 3.4) have a narrow frontage measuring approximately ten metres but they stretch back about 68 metres. The recessed porch opens to the reception hall which is separated from the private areas of the house by a decorative carved screen.

\footnotetext{
${ }^{137} \mathrm{Ho}$, Hasan, and Noordin "An Influence of Colonial Architecture to Building Styles And Motifs in Colonial Cities in Malaysia" unpaginated

${ }^{138}$ Ho, Hasan, and Noordin "An Influence of Colonial Architecture to Building Styles And Motifs in Colonial Cities in Malaysia" unpaginated

${ }^{139}$ Chen 'Architecture' The Encyclopaedia of Malaysia p91

${ }^{140}$ Yeang The Architecture of Malaysia p135

${ }^{141}$ Fels "Conserving the Shophouse City" p6

${ }^{142}$ Yeang The Architecture of Malaysia p135
} 


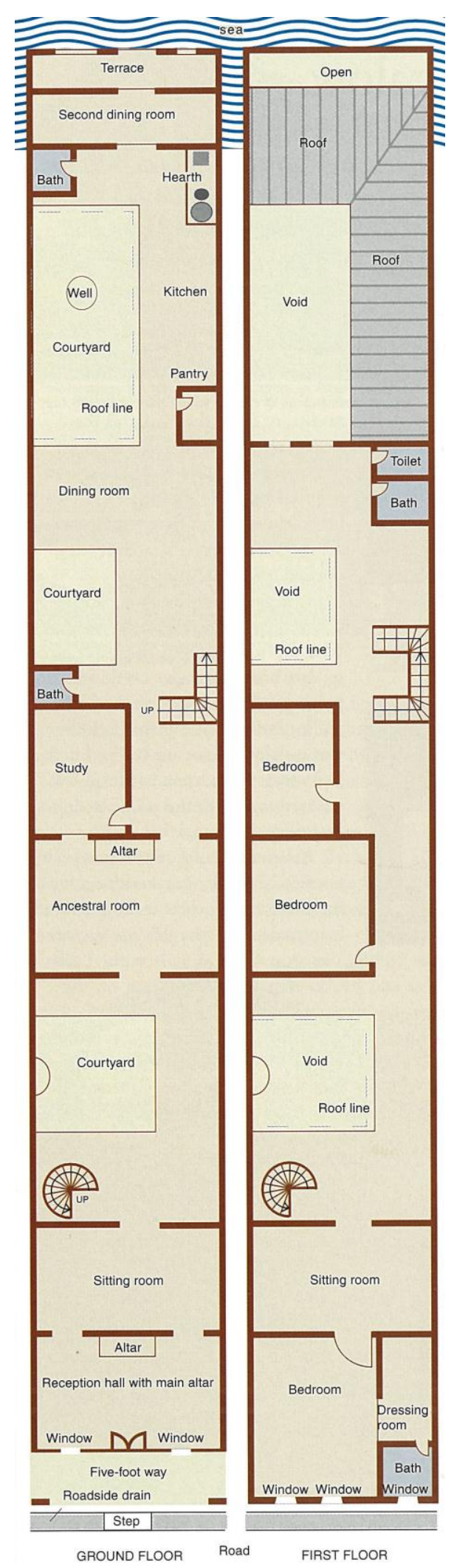

Fig. 3.4 Melakan townhouse ground floor and first floor plan 

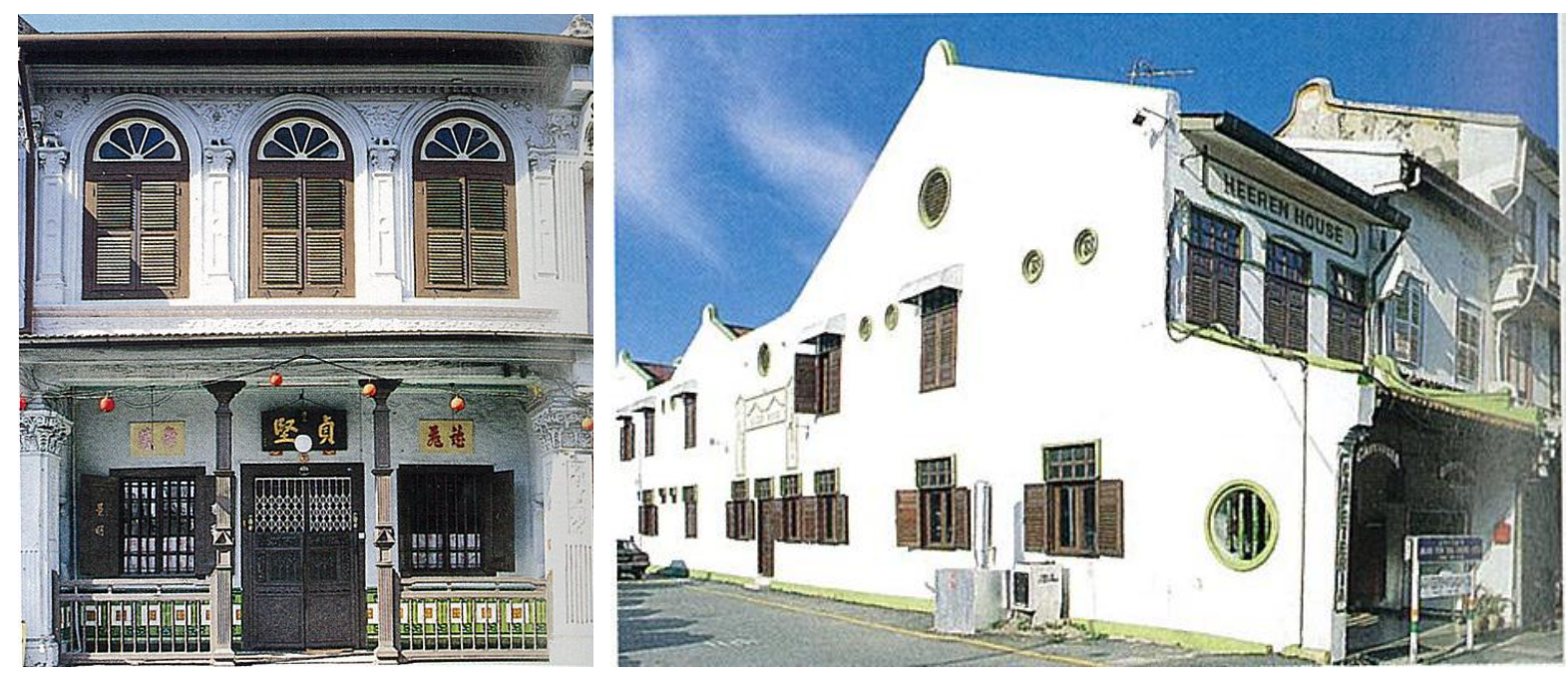

Fig. 3.5 A Melakan townhouse (left) and fig. 3.6 the side view showing the length of a typical Melakan townhouse (right)

The interior organisation of the traditional Chinese townhouse is arranged into areas for shelter, private worship, work and interactions of a domestic, public and ceremonious nature. ${ }^{143}$ Public areas such as the living room and dining room are located on the ground floor while the bedrooms are situated on the first floor. Ismail noted that it was unusual to see houses built in narrow building sites considering there was abundant land in Melaka and that this was probably a straightforward example of the Chinese duplicating houses in their homeland. ${ }^{144}$

Nineteenth century variations of the townhouse do not have a projecting first floor but a lower secondary roof in front to shelter the walkway from sun and rain. ${ }^{145}$ The townhouse is the antecedent of the contemporary terrace house or linear linkhouses which became increasingly in demand from the 1950s onwards to accommodate the growing urban populace.

\footnotetext{
${ }^{143}$ Ismail Houses in Malaysia. Fusion of the East and the West p24

144 Ismail Houses in Malaysia. Fusion of the East and the West p24

${ }^{145}$ Yeang The Architecture of Malaysia p135
} 


\section{Religious}

3) Chinese Temples

The Chinese immigrants who came to Malaysia embraced their religion by building temples dedicated to deities of Taoist, Buddhist and folk beliefs, as well as ancestor worship. The oldest temple in Malaysia, the Cheng Hoon Teng in Melaka is believed to date to as far back as $1645 .{ }^{146}$

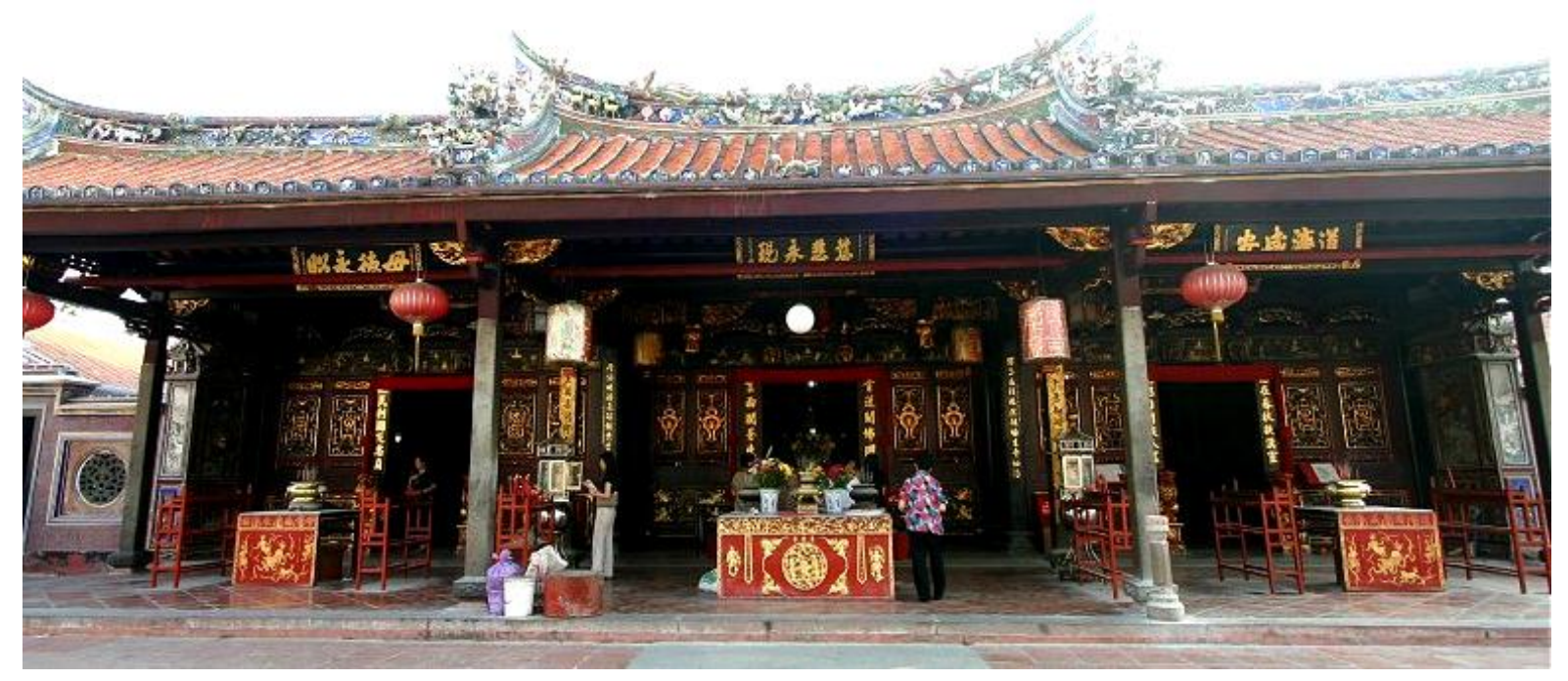

Fig. 3.7 The Cheng Hoon Teng is the oldest Buddhist temple located in Melaka, Malaysia.

The design of the Chinese temple consists of a central building containing the altar facing a courtyard and two side buildings. ${ }^{147}$ The design of a typical Chinese temple is elaborate in its decoration and served as a testimony to the carpentry skills of master builders.

One of the dominant features of a Chinese temple is the ridgeline of the roof which is either horizontal or curved, and decorated with flowers, auspicious animals like dragons, phoenix and religious figures made out of colourful ceramic pieces. These ornaments were meant to symbolized strength, justice and power. ${ }^{148}$ Another distinctive feature includes the exposed structural elements which allows for proper ventilation of halls that are often filled with smoke from burning joss sticks.

\footnotetext{
${ }^{146}$ Yeang The Architecture of Malaysia p128

${ }^{147}$ Yeang The Architecture of Malaysia p128

${ }^{148}$ Chen 'Architecture' The Encyclopaedia of Malaysia p51
} 
$\underline{\text { Public }}$

4) Clan houses/Kongsis

Upon arriving on unfamiliar territory, the Chinese immigrants formed several clan associations comprising of fellow countrymen who shared a common background or who came from the same ancestral village. ${ }^{149}$ These Chinese clan houses are also known as kongsi which translates as 'to share' or 'a shared company'. ${ }^{150}$ The kongsi house was treated as a second home by the Chinese in Malaya, serving as temporary accommodation for members in need, employment agencies, meeting places, banks and social welfare sources. The kongsi members attached great importance to academic achievements, honouring high achievers by inscribing their names on wall plaques.

A typical Chinese clan house consists of only one or two storeys and is usually attached to a temple and a prayer hall. Common features of the clan house include an ornamented clay-tile roof similar to the ones on the Buddhist temples, a big entrance door, a front porch with typically large metal bars that cover the windows which have both louvered panels and canopies.

The Leong San Teong Khoo Kongsi Building, also known as the Khoo Kongsi Building, is one of the most notable examples of clan house architecture in Malaysia. The complex no doubt functions as a typical Chinese clan complex. However, the architecture of the Khoo Kongsi Building is that of a colonial hybrid, an amalgamation of Eastern and Western architectures.

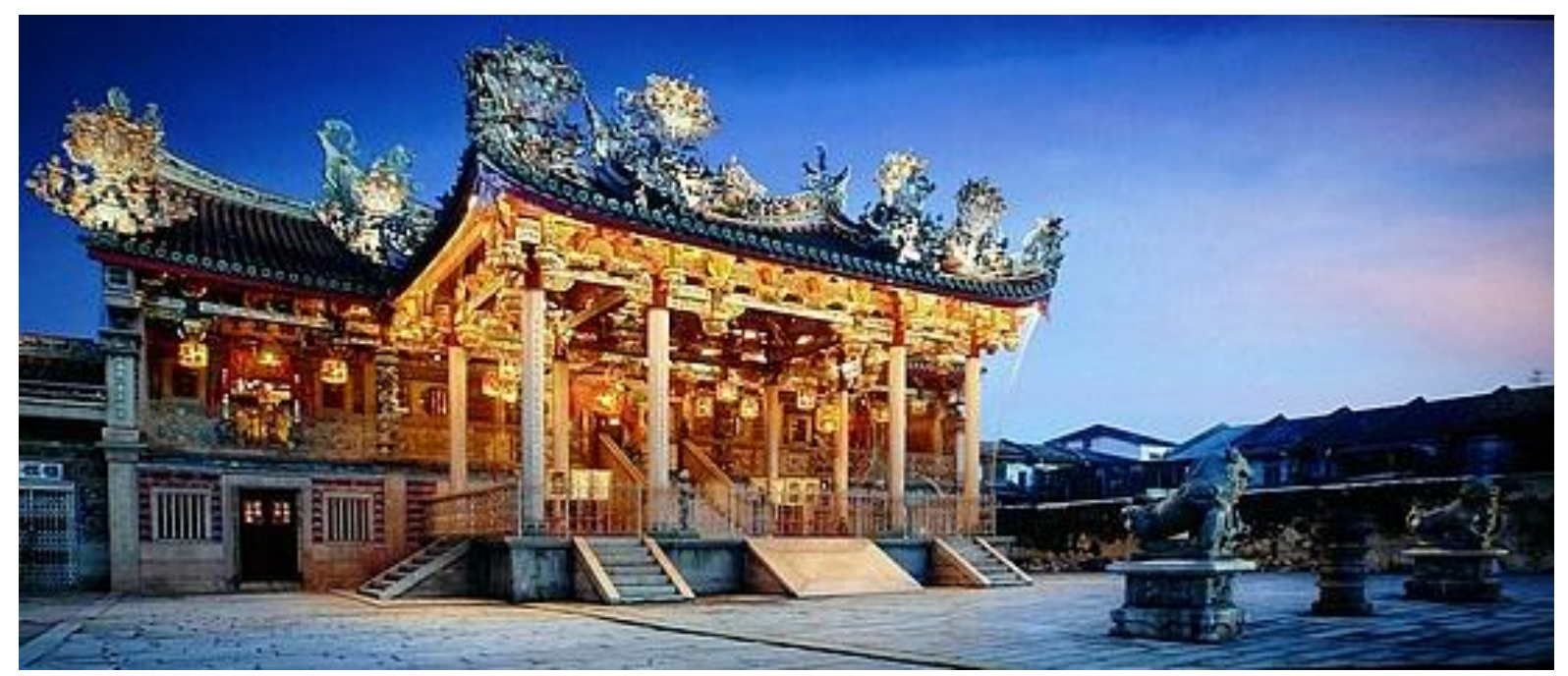

Fig. 3.8 The Khoo Kongsi Building located in Cannon Square, Penang is one of Malaysia's grandest clan complex.

\footnotetext{
${ }^{149}$ Chen 'Architecture' The Encyclopaedia of Malaysia p52

${ }^{150}$ Chen 'Architecture' The Encyclopaedia of Malaysia p52
} 
Located in Cannon Square, Penang, the extravagant building was built in the 1830 s by the descendants of Khoo Chean Kong who migrated to Penang in the late eighteenth century. The initial building was consumed by a mysterious fire just weeks after its completion. It was rebuilt as a scaled-down version but the building was still a masterpiece, nonetheless.

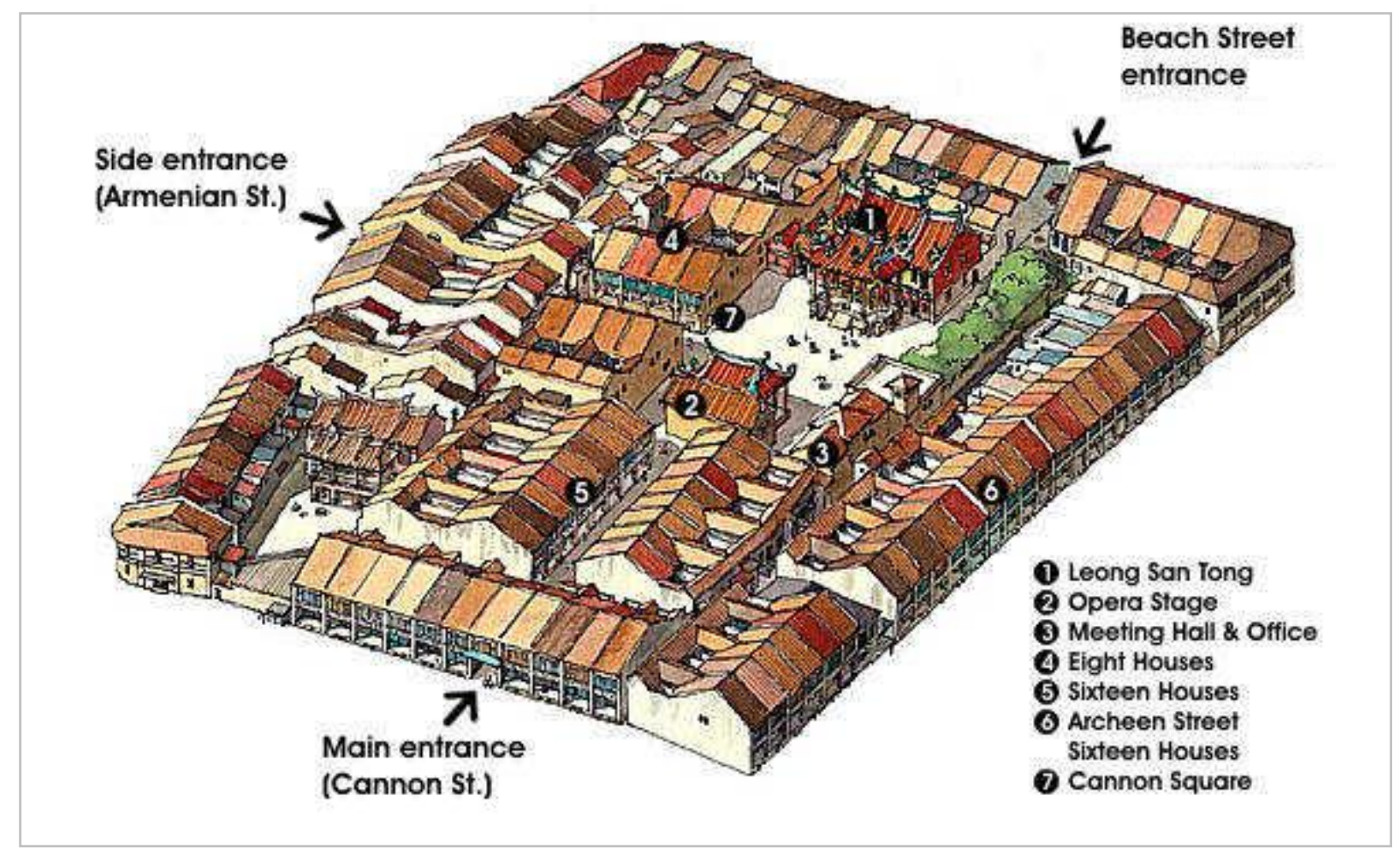

Fig. 3.9 The Khoo Kongsi complex.

The Khoo Kongsi complex consists of the clanhouse Leong San Tong, an administrative building with a meeting hall and offices, an opera stage, and 62 units of terrace houses and shophouses. ${ }^{151}$ The kongsi boasts intricately ornamented walls, pillars and roof. Leong San Tong displays the most spectacular ridge decorations. Stucco sculptures, curved surfaces and wing-shaped ridges with cutand-paste decoration seen on the rooftops of the main hall and the prayer pavilion are features of Southern Fujian architecture. The roof truss consists of the "three cross-beams, five queen-posts" wooden structure, while the side wing and gable wall, which serve as the load-bearing wall, are made of bricks and stones. ${ }^{152}$

\footnotetext{
${ }^{151}$ Leong San Tong Khoo Kongsi "The tour" unpaginated

152 Leong San Tong Khoo Kongsi "The tour" unpaginated
} 
The ground floor of the kongsi temple is uplifted on piers making the three halls of worship accessible by two flights of stairs. ${ }^{153}$ The locals regarded this feature as mimicking the structure and style of a Chinese imperial palace. However, in the construction of a Chinese palace, the uplifted ground floor is solid with clay tamped layer upon layer. ${ }^{154}$ This uplifted feature is more likely adapted from the construction of the vernacular Malay house which was raised on stilts to facilitate adequate ventilation. ${ }^{155}$ It could also be to protect the building from flooding.

Western influences are also evident in the architecture of the Khoo Kongsi building. There is a custom made English wrought iron fence with floral motifs at the upper floor verandah of the main hall. There is a trapezium ceiling in Hock Teik Soo and the Ee Kong Tong halls, a characteristic that is not typical of a Southern Fujian building. ${ }^{156}$ The louvered windows and balusters at the rear verandah, the capital of pilaster on the ground floor of the main hall and the moulding on the grand staircase leading to the main hall are also Western inspired decorations. ${ }^{157}$

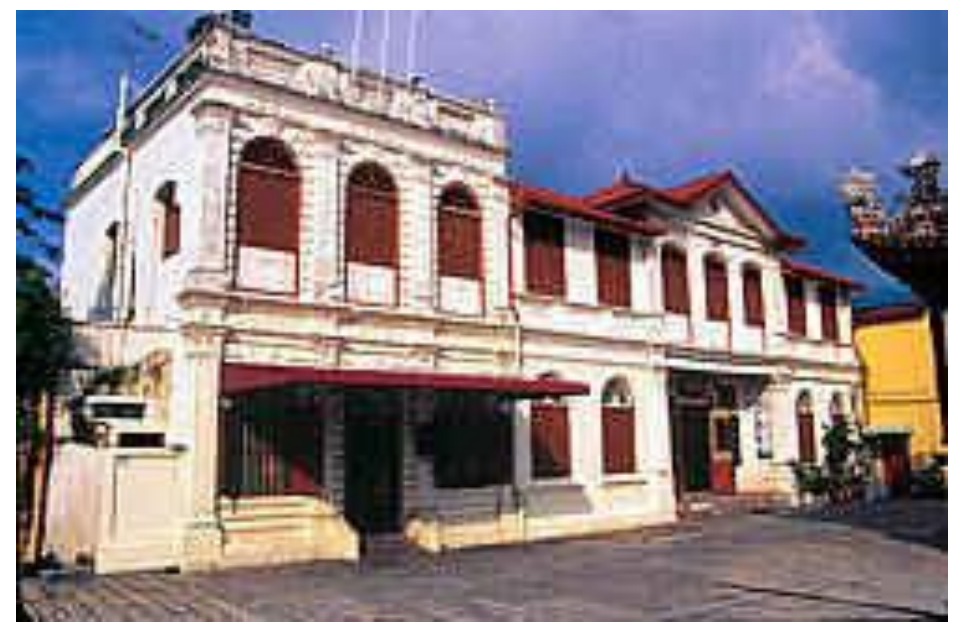

Fig. 3.10 The façade of the administrative building of the Khoo Kongsi is clearly British inspired.

The administrative building of the Khoo Kongsi complex consists of two adjoining double-storey bungalows and displays evidence of the influence of British colonial architecture. One bungalow stands with a parapet on the rooftop whilst the other with a tiled roof.

Although the shophouse, townhouses, temples and kongsis were brought by the Chinese settlers, these building types gradually conform to its new surroundings. Builders developed ingenious methods to manage the tropical climate which included the verandahway that sheltered the walkways as well as provide shade to the front rooms, thick brick walls to insulate, a series of lightwells to bring light and air into the interiors and elaborate shutters, grills, and cast iron lattices that ensure ventilation while providing privacy. ${ }^{158}$ The constantly evolving façade compositions of

\footnotetext{
${ }^{153}$ Chen 'Architecture' The Encyclopaedia of Malaysia p53

${ }^{154}$ Lim "Khoo Kongsi Clanhouse and Community: Transformation of Social and Spatial Relationships" p9

${ }^{155}$ Chen 'Architecture' The Encyclopaedia of Malaysia p53

${ }^{156}$ Leong San Tong Khoo Kongsi "The tour" unpaginated

${ }^{157}$ Leong San Tong Khoo Kongsi "The tour" unpaginated

${ }^{158}$ Fels "Conserving the Shophouse City" p6
} 
the shophouse and the townhouse are a testament to the changes brought about by social, political, cultural and economic conditions.

The construction of the shophouse slowed down during the 1930s depression up until World War II but in the 1960s and 1970s, the shophouse received a new lease of life. The shophouse typology has existed in the country since the nineteenth century but has established itself as a vernacular model and is still considered a favourite building type in the country. The modern shophouse often consists of an amalgamation of shop lots and three to five storeys of office blocks as a result of rising land values. $^{159}$

The shophouse and rowhouse underwent constant development and proliferation and evolved into a form of housing known as the terrace houses or linear linkhouses. In the beginning of the twentieth century, this mass residential housing form became ubiquitous and the most recognizable residential building type in Malaysia. ${ }^{160}$

\section{Colonial Architecture of the Portuguese, Dutch and the British}

Upon their arrival to Malaya, the European colonist, like previous immigrants, brought with them their "world view" as well as European architectural influences. Colonial buildings were designed as clear symbols of imperialism and functioned to confront the local population with the inscription of power and discipline. The colonial rulers erected monumental structures, intended to impress the local inhabitants with their sheer size, permanence and excellence. ${ }^{161}$ European colonialism stressed power through: scale, complexity in design, use of imported materials and imposition of a foreign culture and lifestyle on local people. Although these buildings were new, unfamiliar and considered alien imports, the local inhabitants understood what they were meant to symbolise because, as seen in Malaysian vernacular architecture (as discussed in chapter 1), power and status were understood and expressed in similar ways particularly through the size and location of houses, modern and imported materials, craft and material possessions and furniture.

Administrators were counting on these traditional status-hierarchies to buttress their own superimposed colonial order. ${ }^{162}$ However, although the colonial rulers brought with them a different paradigm, they did not completely reject the existing culture. Vernacular architecture's success as a dwelling place results from superbly rational responses to locally available materials, climate and

\footnotetext{
${ }^{159}$ Chen 'Architecture' The Encyclopaedia of Malaysia p91

${ }^{160}$ Yeang The Architecture of Malaysia p340

${ }^{161}$ Crouch and Johnson Traditions in Architecture p180

162 Bernad "The Architecture of Colonial Presence" unpaginated
} 
requirements of use. It comes as no surprise then, that in adapting to the tropical climate, the colonial architecture transformed to include elements of the vernacular house forms. The colonists learnt from these cultures by their use of available materials and the building of climatically appropriate structures. ${ }^{163}$

Colonial architecture is the re-creation of familiar environments in alien locations. ${ }^{164}$ During the process of dislocation and relocation, the colonial buildings went through transformations to adapt to the new environment while retaining part of their original architectural identity. The colonial occupation also brought about the introduction of new building materials and sophisticated technology as well as the implementation of building legislations and planning controls. These important ordinances paved the way for better infrastructure, town planning and prompted economic growth and the architectural development of the country. This chapter will examine the colonial architecture built in Malaysia by the Portuguese, Dutch and British. This leads to an investigation of architectural strategies employed by the colonial rulers to achieve a hybrid fusion between the vernacular and their culture.

\section{Portuguese (1511-1641)}

The period of European colonialism began when the Portuguese seized Melaka in 1511 in an effort to conquer the new spice route. The economic and political affairs of Melaka were controlled by the Portuguese for 130 years.

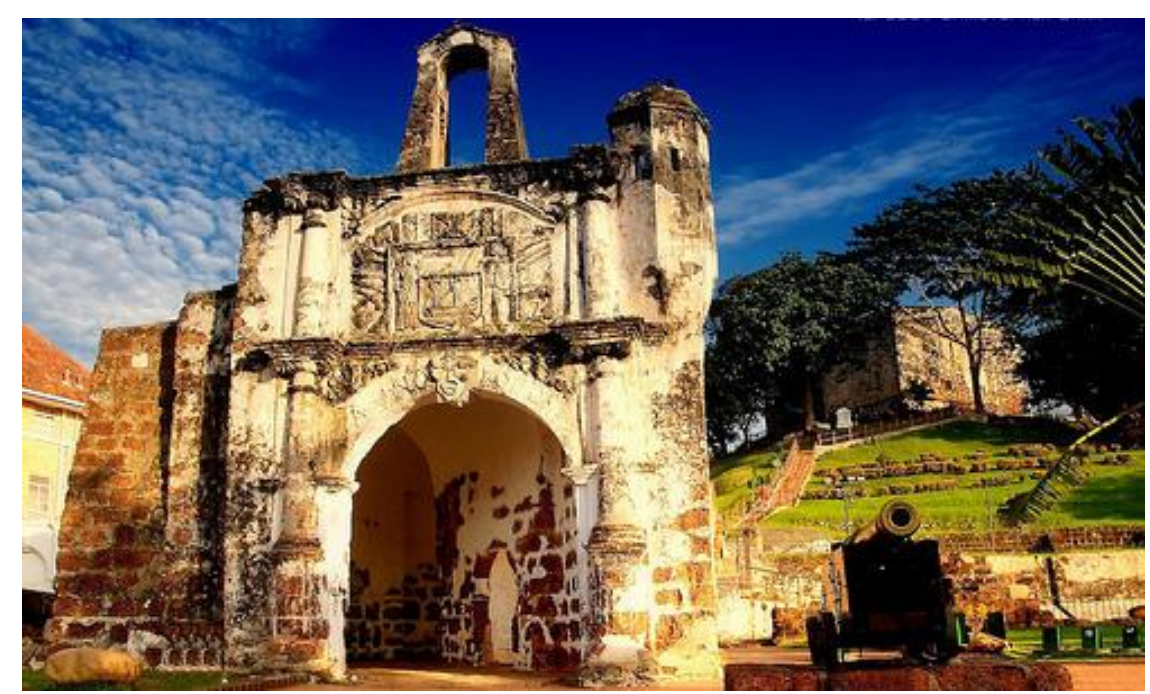

Fig. 3.11 Porta de Santiago, A Famosa fortress or 'The Famous' in Portuguese, Melaka

\footnotetext{
${ }^{163}$ Oliver Built to meet needs. Cultural Issues in Vernacular Architecture p169

${ }^{164}$ Abel Architecture and Identity Responses to Cultural and Technological Change p149
} 
The significance of the Portuguese architecture in Malaysia is mainly evident in the construction of fortifications and religious buildings rather than residential houses. One of the most notable remains of the Portuguese colonialism is A Famosa, a fortress built by Alfonso d'Albuquerque. The fortress was completed in 1512 and once consisted of long ramparts and four major towers. One tower was a four-storey keep while the others served as an ammunitions storage room, captains' residences and offices' quarters. ${ }^{165}$ The masonry wall encircled the entire hill and was 60 feet high and 15 feet thick. Nine bastions equipped with underground quarters, stores and stables, were strategically built around the walls. ${ }^{166}$ Dutch besiegers destroyed the fortress in 1641 and all that is spared of the nearly annihilated fortress is a tiny gate called the Porta de Santiago, which can still been seen in Melaka.

The rule of the Portuguese not only introduced European architecture to the country but also popularised the use of stone and locally available laterite (red clay) as building materials. They also initiated the manufacture and use of roofing tiles as a precaution against fire which altered the Malay houses. ${ }^{167}$ It was also during this period that Melaka developed a form of town planning and drainage system. ${ }^{168}$ The Portuguese taxed buildings based on frontage width. This policy accounts for the construction of deceptively narrow facades to deep shops along the streets which were typical of Chinese shophouses. A building with a facade no more than twelve feet across can easily extend backwards 200 feet.

There were a number of suburbs outside the fortified town where the Portuguese resided. Tranqueira, located one kilometre northwest of Melaka was one of the most important suburbs and the main residential quarters of the city. The name 'Tranqueira' derived from the presence of earthern rampart of the fortress. ${ }^{169}$ The suburb was rectangular in shape with a northern walled boundary. The houses in Tranqueira, now better known as Tengkera, were made of timber but roofed with tiles. ${ }^{170}$ The other suburbs were Hilir and Sabbac. Hilir consisted of timber houses with attap roofs while Sabbac comprised timber houses that were raised on stilts over the river. ${ }^{171}$ Based on these descriptions, these houses presumably took on the form, or a variation, of the Malay traditional house.

\footnotetext{
165 'A Famosa Fortress' Salkow, Howard "Australian experience builds global perspective” unpaginated

${ }^{166}$ Yeang The Architecture of Malaysia p29

${ }^{167}$ Yeang The Architecture of Malaysia p28

${ }^{168}$ Chen 'Architecture' The Encyclopaedia of Malaysia p62

${ }^{169}$ Yeang The Architecture of Malaysia p28

${ }^{170}$ Yeang The Architecture of Malaysia p28

${ }^{171}$ Yeang The Architecture of Malaysia p28
} 
Many Portuguese soldiers married local women and settled permanently in Melaka. The descendents of the Portuguese still live in settlements such as Praya Lane and Bandar Hilir. ${ }^{172}$ The homes of the Portuguese settlement could easily be mistaken for a typical Malay dwelling. However, upon closer look, telling them apart from the houses of the local Muslims were the displays of Catholic motifs such as an altar and religious portraits perched high on their walls. ${ }^{173}$
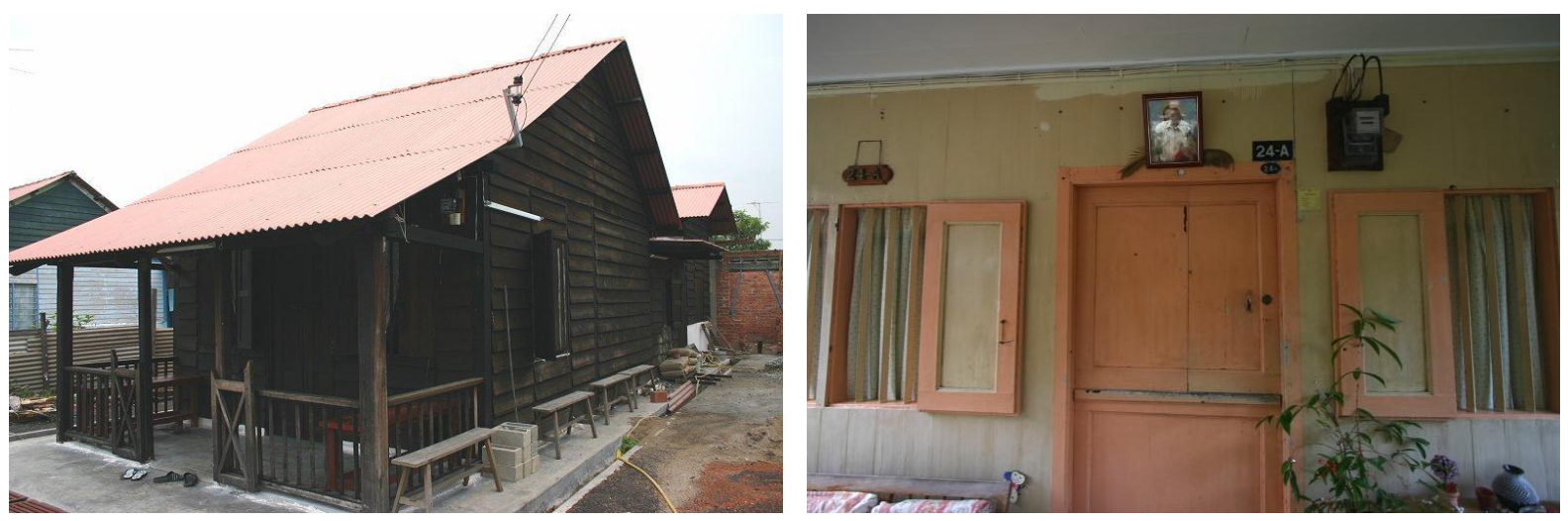

Fig. 3.12 A house restored by the Melaka Museum Corporation which showcases traditional Portuguese house in Melaka (left) and fig. 3.13 a Portuguese dwelling displaying Catholic motifs on the wall (right)

Significant structures such as the A Famosa fortress were built for defensive purpose while the Portuguese settlements were contained within the constraints of masonry walls. The houses within these suburbs took on descriptions that resembled the Malay houses (timber houses built on stilts with thatched roofs), suggesting that the Portuguese did not introduce new domestic building types and instead conformed to the traditional forms of dwelling.

Apart from establishing trade monopolies, the Portuguese intended to spread Roman Catholicism, erecting religious buildings such as the Jesuit College of St Paul (1548) and St Paul's Church (1521). As these defensive and religious buildings were built to serve the individual purposes of the colonial rulers, they did not contribute to vernacular forms, but instead are merely transplanted forms. These forms maintained the original set of ideas that governed them prior to entering the region and responded little to their new surroundings. ${ }^{174}$

\footnotetext{
${ }^{172}$ Tye "Portuguese Settlement, Kampung Hilir, Malacca“ unpaginated

${ }^{173}$ Tye "Portuguese Settlement, Kampung Hilir, Malacca" unpaginated

${ }^{174}$ Heath Vernacular Architecture and Regional Design: Cultural Process and Environmental Response p9
} 


\section{Dutch (1641-1795)}

With the assistance of the state of Johor, the Dutch East India Company successfully defeated the Portuguese in January 1641 in order to gain control over Melaka. The Dutch occupation brought about a wider range of buildings, constructing residential brick houses and a large townhall known as the Stadhuys which served as the residence of the Dutch Governor and accommodated the Dutch civil administration. ${ }^{175}$

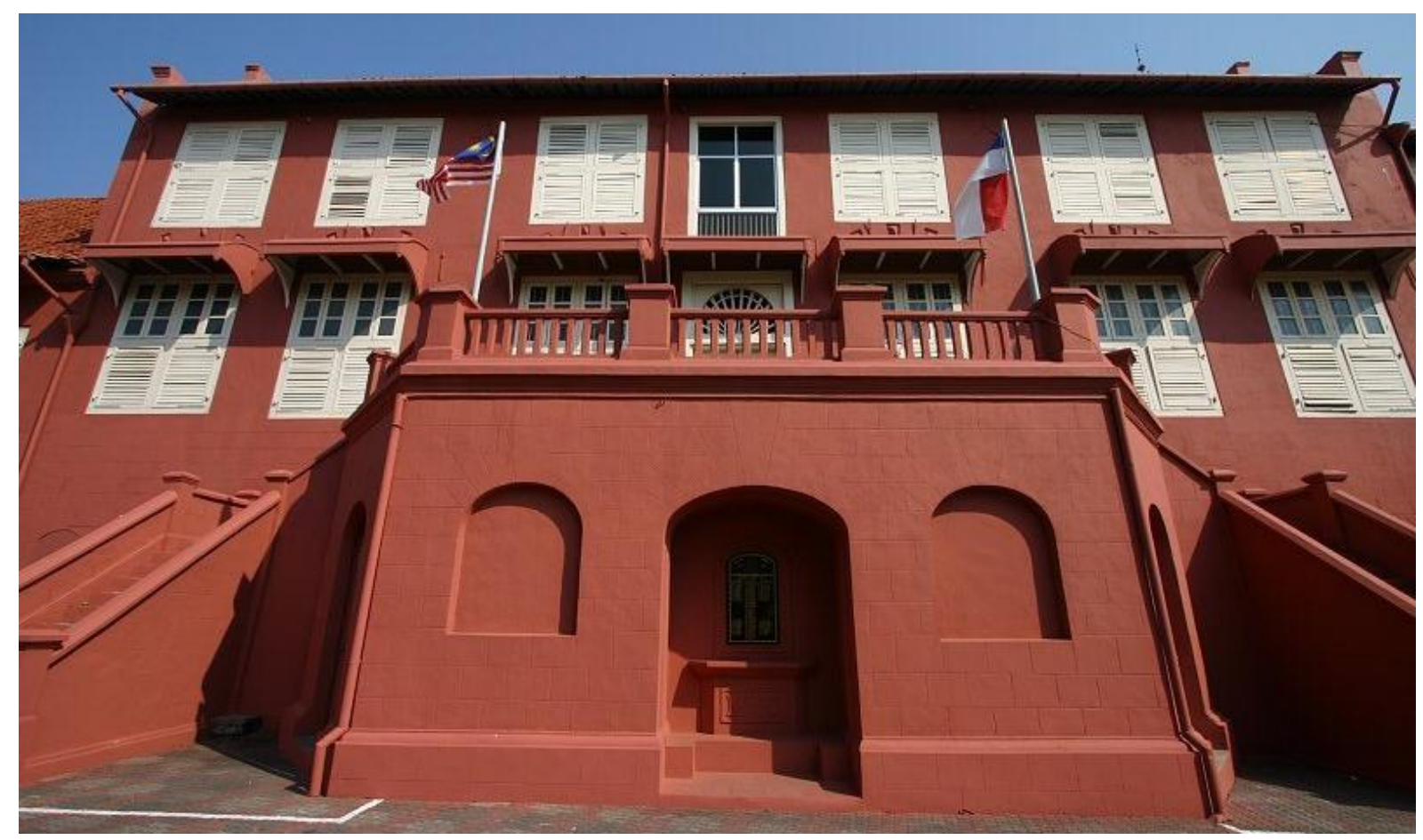

Fig. 3.14 The Stadthuys, Melaka

The buildings display thick masonry walls and fine Dutch hardwood carvings that have been carefully preserved. The gable designs, louvered windows and heavy solid timber door, set into archways, are also common features of the Dutch style. ${ }^{176}$ According to De Witt, the Stadthuys of Melaka is a reproduction of the former Stadhuis (town hall) of the Frisian town of Hoorn in the Netherlands and was described as an excellent representation of the now demolished Frisian building. ${ }^{177}$ The distinctly red coloured building was renovated and converted into a state museum in 1982.

\footnotetext{
${ }^{175}$ Yeang The Architecture of Malaysia p35

${ }^{176}$ Chen 'Architecture' The Encyclopaedia of Malaysia p63

${ }^{177}$ De Witt "The Stadthuys of Malacca" unpaginated
} 


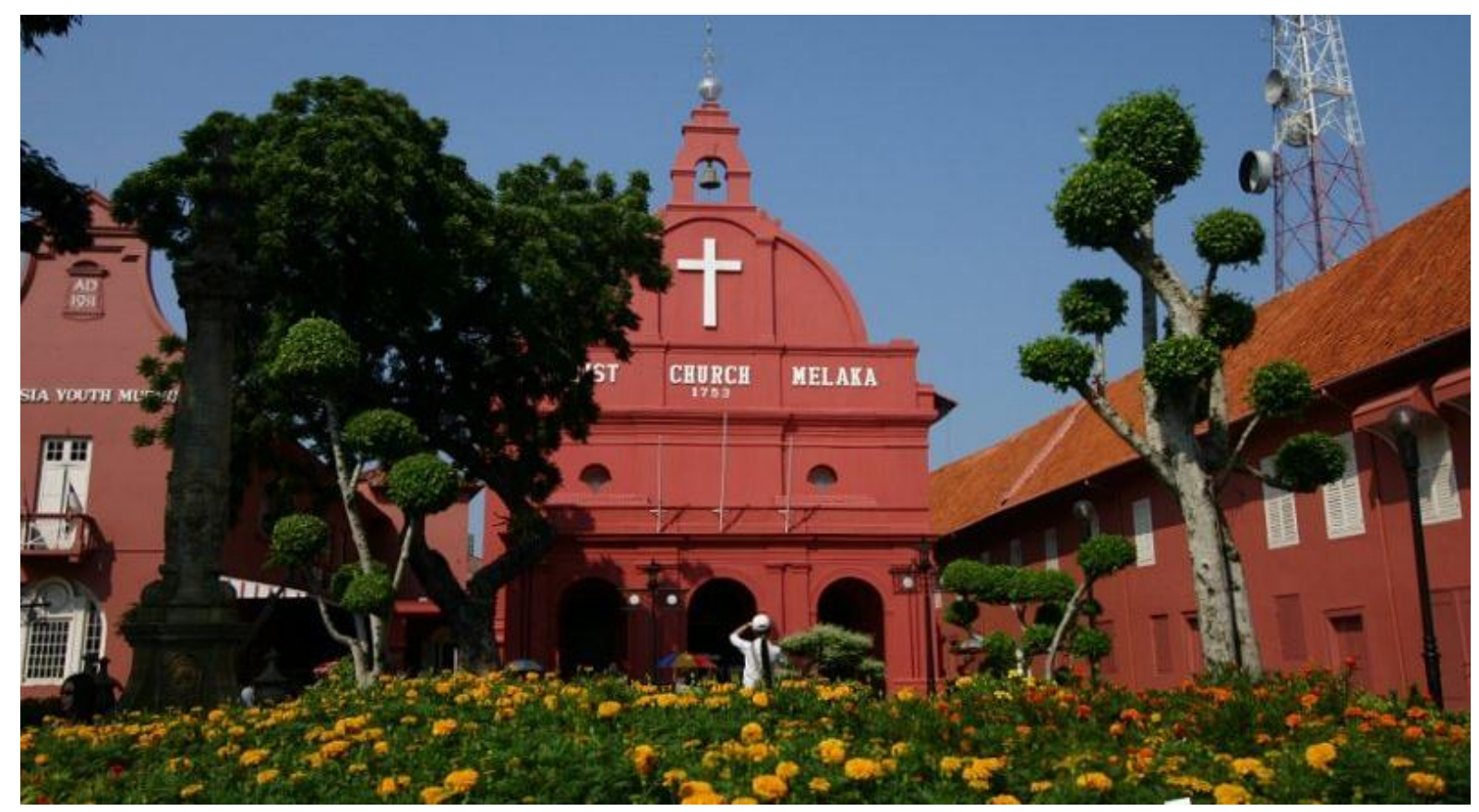

Fig. 3.15 The Christ Church (centre) stands alongside the Stadthuys (right), Melaka

The Christ Church, built in 1753, sits between the General Post Office and the Stadhuys. The building is 82 feet long ( $25 \mathrm{~m}$ approx), 40 feet wide ( $12 \mathrm{~m}$ approx) and 42 feet high ( $13 \mathrm{~m}$ approx). ${ }^{178}$ The façade consists of a symmetrical half circle topped by a small bell arch. The church followed a robust rectangular plan without aisles and exhibits massive walls, red granite plinths, and Dutch roof tiles. The Dutch applied their superior architectural skills in building with bricks, which the local builders were not familiar with. The beams of the church were expertly constructed by using a single tree trunk and have no joints. ${ }^{179}$

The Dutch introduced a methodical approach to the urban planning in Melaka. They standardised the use of bricks, defined building lines, inspected party walls and drain construction and implemented industrial zoning. ${ }^{180}$ This can be seen in Dutch settlements in Melaka where the Dutch rulers built houses to accommodate their government officers and the elite groups of their society. ${ }^{181}$

\footnotetext{
${ }^{178}$ Yeang The Architecture of Malaysia p37

${ }^{179}$ Yeang The Architecture of Malaysia p37

${ }^{180}$ Arch Net "Malacca" unpaginated

${ }^{181}$ Kamal “Heritage Cities of Malaysia: The Penang Chapter, Penang, Malaysia” unpaginated
} 

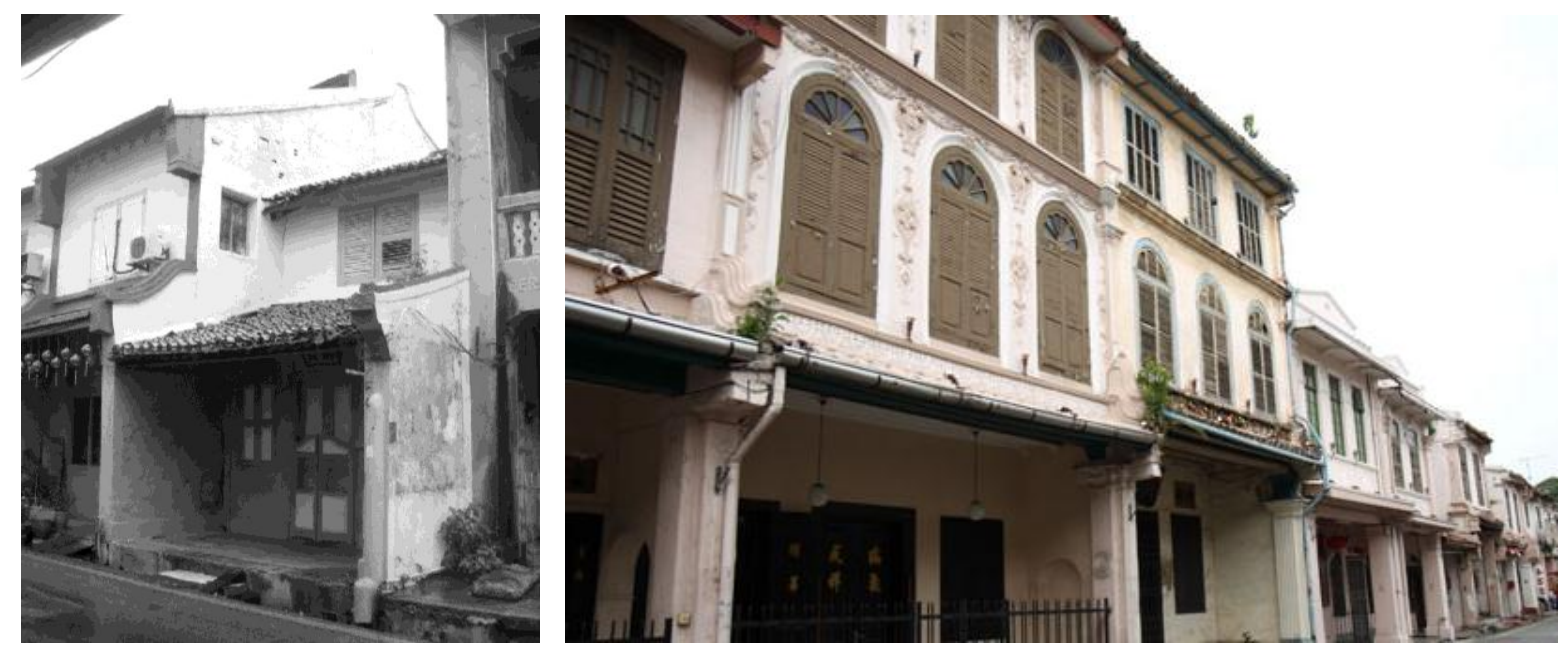

Fig. 3.16 Early townhouses on Heeren Street built before and during mid eighteenth century (left) and fig. 3.17 newer townhouses on Heeren Street built after the mid eighteenth century (right)

Many Dutch-styled townhouses can be found along Jalan Tun Tan Cheng Lock, also commonly known as Heeren Street, and Jalan Hang Jebat, known as Jonker Street. Heeren Street derived from the Dutch word 'Heerenstraat' which translates as Gentlemen's Street while Jonker Street derived from the word 'Jonkerstraat' which literally translates as Young Noblemen's Street. ${ }^{182}$ The townhouses along this street were built during the Dutch Colonial period and were of residential houses built prior to and during the mid eighteenth century as well as houses constructed after the mid eighteenth century. The townhouses were variations of the Chinese shophouses and were owned by wealthy Chinese merchants for business or residential purposes.

The building façades are symmetrical with one centralized door and two side windows. The main building materials are brick (walls) and timber (roof) while the original wall surface materials were lime plaster and lime wash. ${ }^{183}$ The interior plan is centred on an open courtyard or lightwell to provide light and ventilation. The window designs are European, Chinese or Malay influenced, while the columns and pilasters are Classical (Doric or Corinthian). The roof tiles and rounded gable ends were features originating from China. The planning principles of the townhouses were essentially Chinese, but the characteristics of these townhouses that were distinctively Dutch include:

- the deep plan and narrow frontage

- the front door that has a upper and lower half, reminiscent of Dutch stable doors

- the brickwork of the drainage system

\footnotetext{
${ }^{182}$ Kamal "Heritage Cities of Malaysia: The Penang Chapter, Penang, Malaysia" unpaginated

${ }^{183}$ U.S. Embassy Malaysia and Badan Warisan (Heritage Trust) Malaysia "Malacca“unpaginated
} 
- the materials used for the steps at the main entrance, and at the doorway of the passage leading to the air well which indicated the social status of the owner

- the hoods above the kitchen which were made out of wood and similar to that found in the kitchen in the Stadhuys.
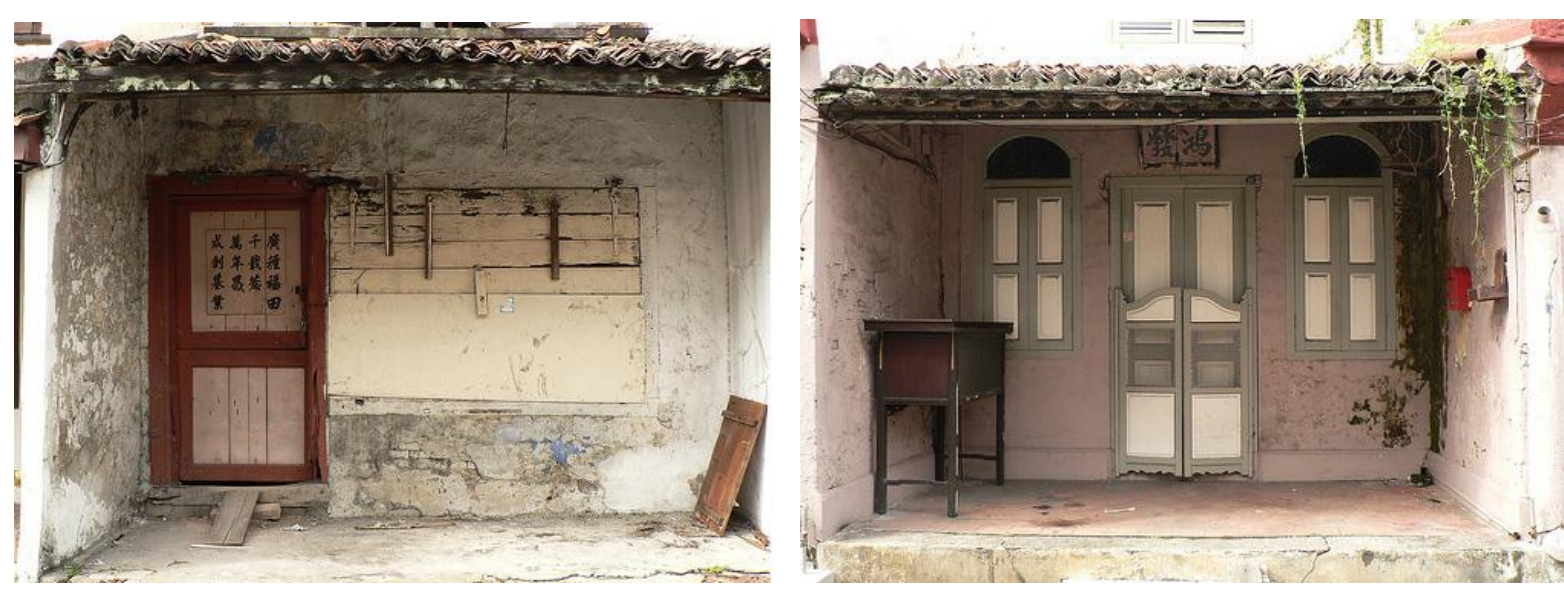

Fig. 3.18 and fig. 3.19 Two old houses on Heeren Street showing lime plaster walls and doors reminiscent of Dutch stable doors.

The townhouses built after the mid eighteenth century have undergone transitions of styles, materials and designs. The upper floors extended beyond the walkway and two to three storeys higher. The houses were considered to be earlier models of low-rise, mixed use and high density living. ${ }^{184}$

Similar to the structures left by the Portuguese, the Stadthuys and the Christ Church are also considered to be transplanted forms that responded little to contextual settings. These buildings are reproductions of building types found in their homeland and were relocated during the colonial conquests. While these building types were categorised as replicas, the Dutch styled townhouse that emerged in Melaka, however, are considered to be vernacular forms that responded to regional dynamics. These houses demonstrated vernacular tendencies as they underwent a hybrid fusion between European, Chinese or Malay architectural styles.

\footnotetext{
${ }^{184} \mathrm{Ho}$, Hasan, and Noordin "An Influence Of Colonial Architecture To Building Styles And Motifs In Colonial Cities In Malaysia" unpaginated
} 


\section{British (1795-1941) and (1945-1957)}

The British occupied the Malay Peninsula in the late eighteenth century. Their reign was briefly disrupted by the invasion of the Japanese in December 1941, but they reoccupied the region in 1945. The British occupation in Malaysia brought about significant changes to the local architectural scene as a large number of buildings were built during the British colonial administration In most British colonial countries, the Public Works Department (PWD) was entrusted to design and construct the public sector buildings such as government offices, court buildings, schools, station buildings, quarters or human resources and plantations. ${ }^{185}$ The PWD was formed in 1872. Most of the architects of the PWD were expatriates although some draughtsmen and technicians were locals. ${ }^{186}$ Three men can be identified as having significant roles in the construction of the colonial architecture left by the British. They were Arthur Charles Norman (1858-1944), Charles Edwin Spooner (1853-1909) and Arthur Benison Hubback (1871-1948). They all had spent time in India, which contributed to the prevailing Oriental elements in some of the buildings they designed.

During the British colonial period, new building legislations were implemented in order to improve the city. Frank Swettenham, a British administrator, introduced a policy in 1884 which stated that attap hut settlements had to be rebuilt in more durable materials such as bricks and tiles. ${ }^{187}$ This building regulation was implemented as a result of several major blazes which caused severe damaged to wooden structures in towns. In 1882, the British also introduced the 'five foot way' which is a sheltered footpath along shophouses to protect pedestrians from sun and rain. ${ }^{188}$ The five foot way design is still a common characteristic of the present day shophouses.

\section{The Architectural Styles of the British}

The British introduced a range of new building forms for civic, residential, administrative and recreational buildings. The British colonists and settlers resided in detached forms of houses such as the bungalows and villas, and established clubhouses reminiscent of architecture of their homeland. The British colonial architecture itself is essentially a hybrid consisting of several architectural styles including Moorish, Tudor Revival, Neo-Classical and Neo-Gothic. ${ }^{189}$

\footnotetext{
${ }^{185}$ Ho, Hasan, and Noordin "An Influence of Colonial Architecture to Building Styles and Motifs in Colonial Cities in Malaysia" unpaginated

${ }^{186}$ Yeang The Architecture of Malaysia p154 The definition for towkay is sir or master and is used as a form of an address. The word is of a Chinese origin.

${ }^{187}$ Yeang The Architecture of Malaysia p63

${ }^{188}$ Yeang The Architecture of Malaysia p51

${ }^{189}$ Ahmad "The Architectural Styles of The British Colonial Buildings In Malaysia” unpaginated
} 


\section{1) Moorish}

The Moorish style was evident in many public buildings in Kuala Lumpur built during the British Colonial period such as the Court of Appeals, the old Kuala Lumpur High Court, Kuala Lumpur Railway Station and the Sultan Abdul Samad Building.

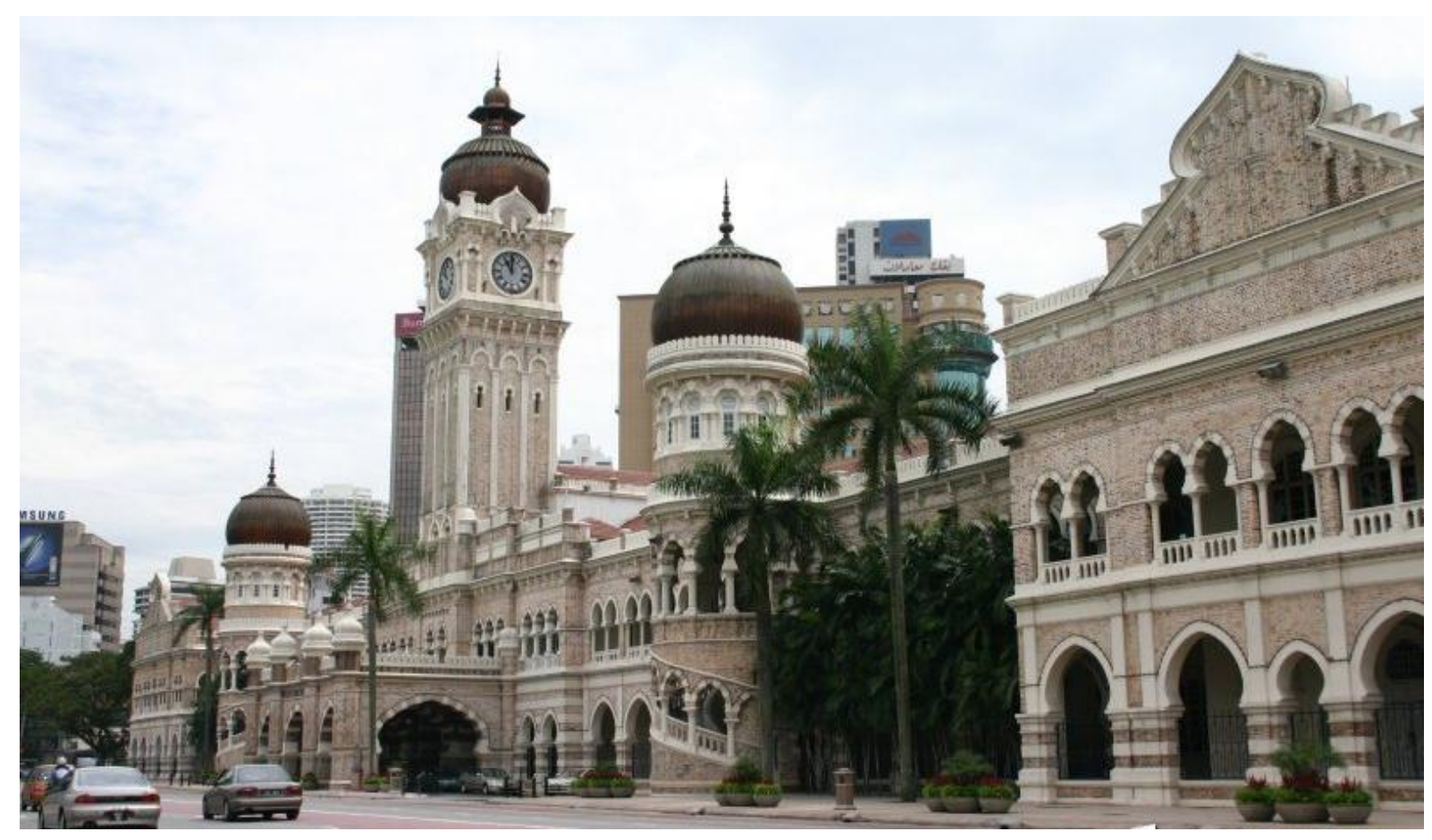

Fig. 3.20 The Sultan Abdul Samad building, Kuala Lumpur

The Sultan Abdul Samad Building is one of Kuala Lumpur's first architectural landmarks as it stands grand in scale and dramatic in style. The initial purpose of the building was to house the colonial State Government of Selangor but upon completion it housed the entire Federated Malay States (FMS) administration. ${ }^{190}$ Construction of the building commenced in 1893 and was completed in 1896. The initial plan was drawn up by architect Arthur Charles Norman ${ }^{191}$, a senior government architect of the PWD in Malaya, in the Classical Renaissance style. The State Engineer and Director of the PWD, Charles Edwin Spooner ${ }^{192}$, approved the general layout of the plan but deemed the style inappropriate for the climate and environment. Having had work experience in Ceylon, he suggested

\footnotetext{
${ }^{190}$ National Library of Malaysia "Sultan Abdul Samad Building” unpaginated

${ }^{191}$ Arthur Charles Alfred Norman was a senior government architect of the Public Works Department (PWD) in Malaya between 1883 and 1903. Norman was born in Plymouth, England, and received his professional education from his architect father before embarking to Selangor to work as an architect in 1883. Norman was the architect responsible for many of Malaysia's historical buildings such as Sultan Abdul Samad Building (1894-97), St. Mary's Church (1894), Selangor Club Building (1890), JKR 92 Memorial Library and Museum, formerly known as the Government Printing Office (1907-09) and others including the Victoria Institution (1894) and Carcosa (1897).

192 Charles Edwin Spooner was born in Wales. He received his education and engineering training at Trinity College Dublin. He worked for the PWD in Ceylon from 1876 to 1891. In 1891 he was appointed State Engineer for Selangor and in 1901 General Manager of the Federated Malay States Railways.
} 
an 'Oriental' style which would be more responsive to climate and was considered well suited to the tropical and cultural environment. ${ }^{193}$ The plan of the Sultan Abdul Samad Building was an asymmetrical F-shape but the exterior of the building adopted the 'Moorish' style which was a mixture of European function and Islamic form. ${ }^{194}$ Both Norman and Spooner's knowledge, styles and ideas which they absorbed from northern India, led to the use of Moorish architecture in the building's design. ${ }^{195}$ The style not only accommodated the tropical climate, but it also became an acknowledgement of its cultural and social environment. Perhaps, as Abel suggested, the architecture of the British administrative reflected Islamic architecture as a way to 'sweeten the imperial pill', relying on the assumption that it was in keeping with the local religion. ${ }^{196}$

The building is two storeys high, with a 143 feet high central clock tower. It stretches 400 feet along Jalan Raja and at the time of its completion, possessed a commanding presence over smaller shops and townhouses around it. A three and a half metre wide arcaded verandahway skirts around both floors. Several forms of arches were used, such as pointed arch, ogee arch, horse-shoe arch, multifoil arch and the Tudor arch. ${ }^{197}$ The building consists of three towers which have Middle Eastern inspired onion-shaped domes with copper coverings. ${ }^{198}$ The building is constructed of red brick with imitation stone dressing with a tiled roof. The floor finish consists of Indian patent stone adorned with Islamic geometrical patterns. ${ }^{199}$

\section{2) Neo-Classical}

The Neo Classical style was an architectural style produced by the Neo-Classical movement that began in the mid-eighteenth century. In the late nineteenth and twentieth century, many of the public buildings in Malaysia commissioned emulated this Classical Revival style that was so prevalent in England at the time.

The building that best exemplified this style is the Ipoh Railway Station. As there were no precedent railway stations at the time, British colonists had to import new building types. The station, dubbed 'the Taj Mahal' was built from 1914 to 1917 and designed by architect, Arthur Benison Hubback. ${ }^{200}$

\footnotetext{
${ }^{193}$ Yeang The Architecture of Malaysia p77

${ }^{194}$ Yeang The Architecture of Malaysia 777

${ }^{195}$ Chen 'Architecture' The Encyclopaedia of Malaysia p83

${ }^{196}$ Abel Architecture and Identity Responses to Cultural and Technological Change p168

${ }^{197}$ Yeang The Architecture of Malaysia p77

${ }^{198}$ Chen 'Architecture' The Encyclopaedia of Malaysia p83

${ }^{199}$ Yeang The Architecture of Malaysia p77

${ }^{200}$ Chen 'Architecture' The Encyclopaedia of Malaysia p80 Brigadier General Arthur Benison Hubback worked as a senior architect in the Public Works Department in Calcutta, India prior to working in Malaya. His work experience in India equipped him with considerable knowledge in building for the tropics, evident in his workmanship.
} 
At the time, railway stations were the ultimate symbol of modernisation in the main towns of the Peninsular Malaysia. The imposing scale and extravagance of this style was suitable for the design of the station as it signified status, power and prestige.

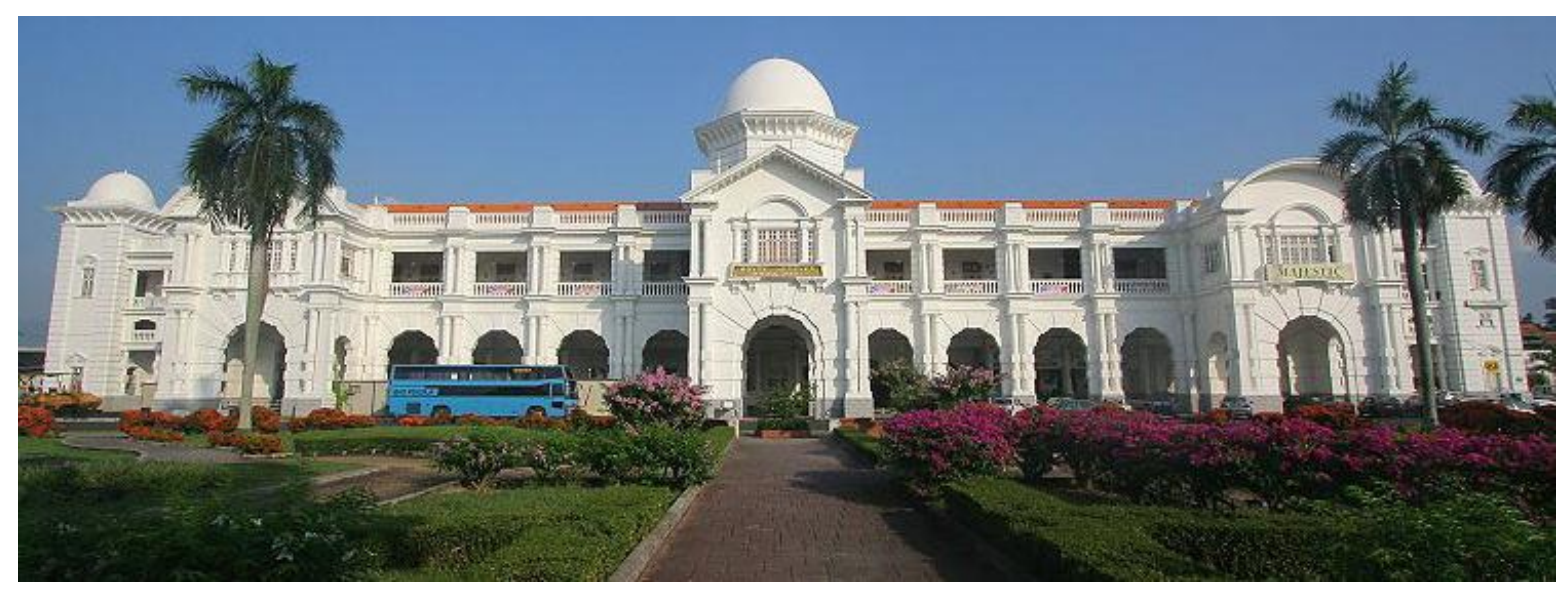

Fig. 3.21 The Ipoh Railway Station, Perak

The station was heavily decorated with Neo Classical elements such as keystones, Corinthian columns, pilasters, half globed domes, and arches. ${ }^{201}$ Hubback made allowances to adapt to the tropical climate by introducing deep continuous arcade loggias on the ground floor that ran 183 metres along the entire length of the station's frontage and provided shelter and shade. ${ }^{202} \mathrm{He}$ also designed broad verandahs on the upper floors to allow for adequate ventilation. The interior of building conveyed a tropical ambience, with high ceilings and airy verandahs.

Although there may not seem to be a conceivable local parallel, similarities can be drawn between the role of the railway station and the longhouse as civic buildings that integrate transportation services. A longhouse is built more or less equidistant to the river as the river was the main source of water and an important means of travel and transportation. The longhouses were usually built with their longitudinal axis parallel to the river. ${ }^{203}$ Being able to watch the river to see who comes and goes was important to people who live along it, as a matter of security and interest. ${ }^{204}$

Similar to the railway station, the longhouse serves as a terminal or 'terminus', the point at which boats depart and arrive. In some longhouses, there is usually a parapet along the front of the gallery which bears resemblance to train platforms in front of railway tracks. The parapet is made of only a

\footnotetext{
${ }^{201}$ Chen 'Architecture' The Encyclopaedia of Malaysia p80

202 Chen 'Architecture' The Encyclopaedia of Malaysia p80

${ }^{203}$ Winzeler The Architecture of Life and Death in Borneo p73

${ }^{204}$ Winzeler The Architecture of Life and Death in Borneo p74
} 
few horizontally placed planks which allowed the occupants to sit on the floor or low benches and look over the river. ${ }^{205}$
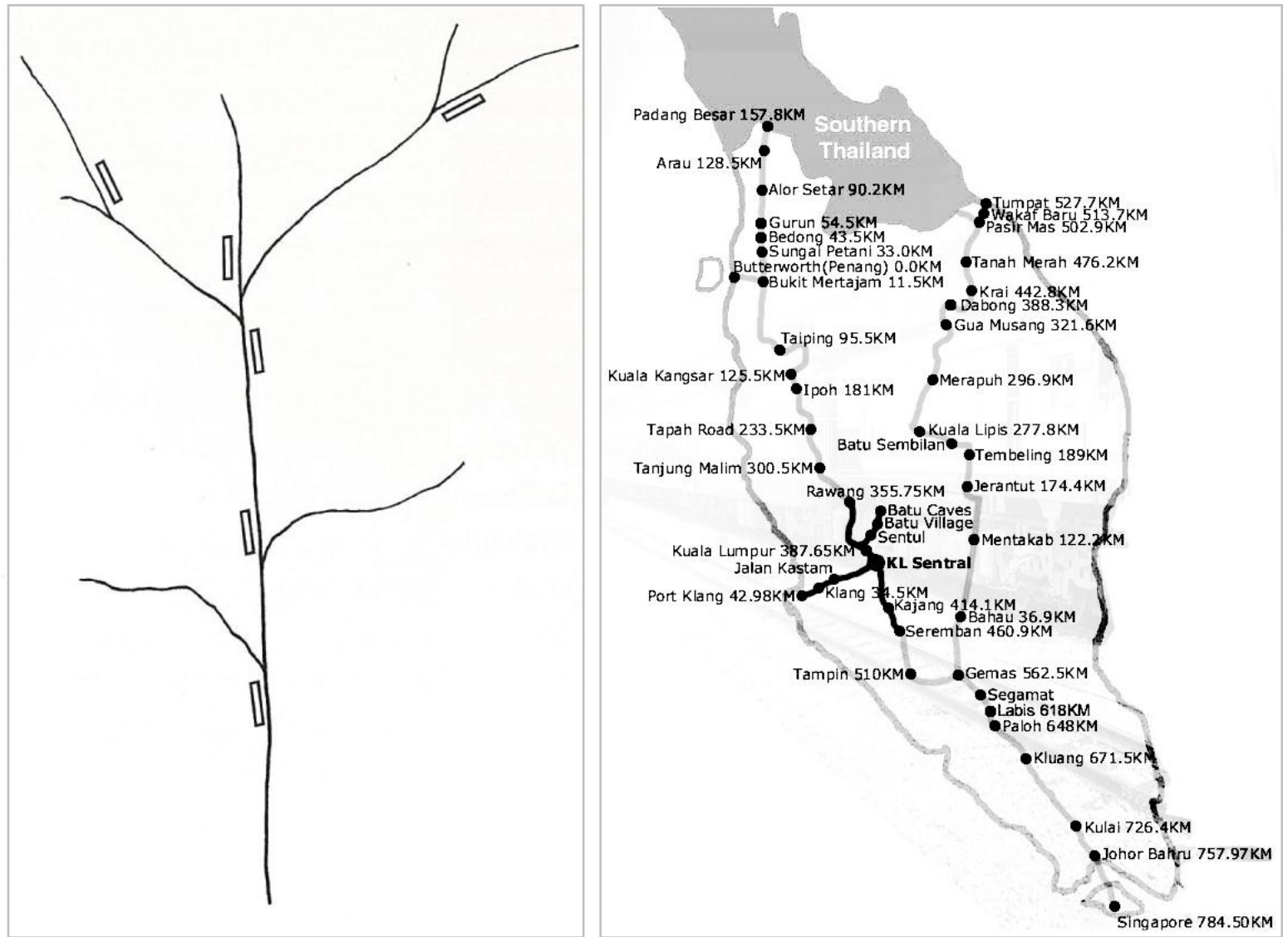

Fig. 3.22 Common arrangement of Iban longhouses on a main river (left) and side streams and fig. 3.23 the KTMB Railway map (right)

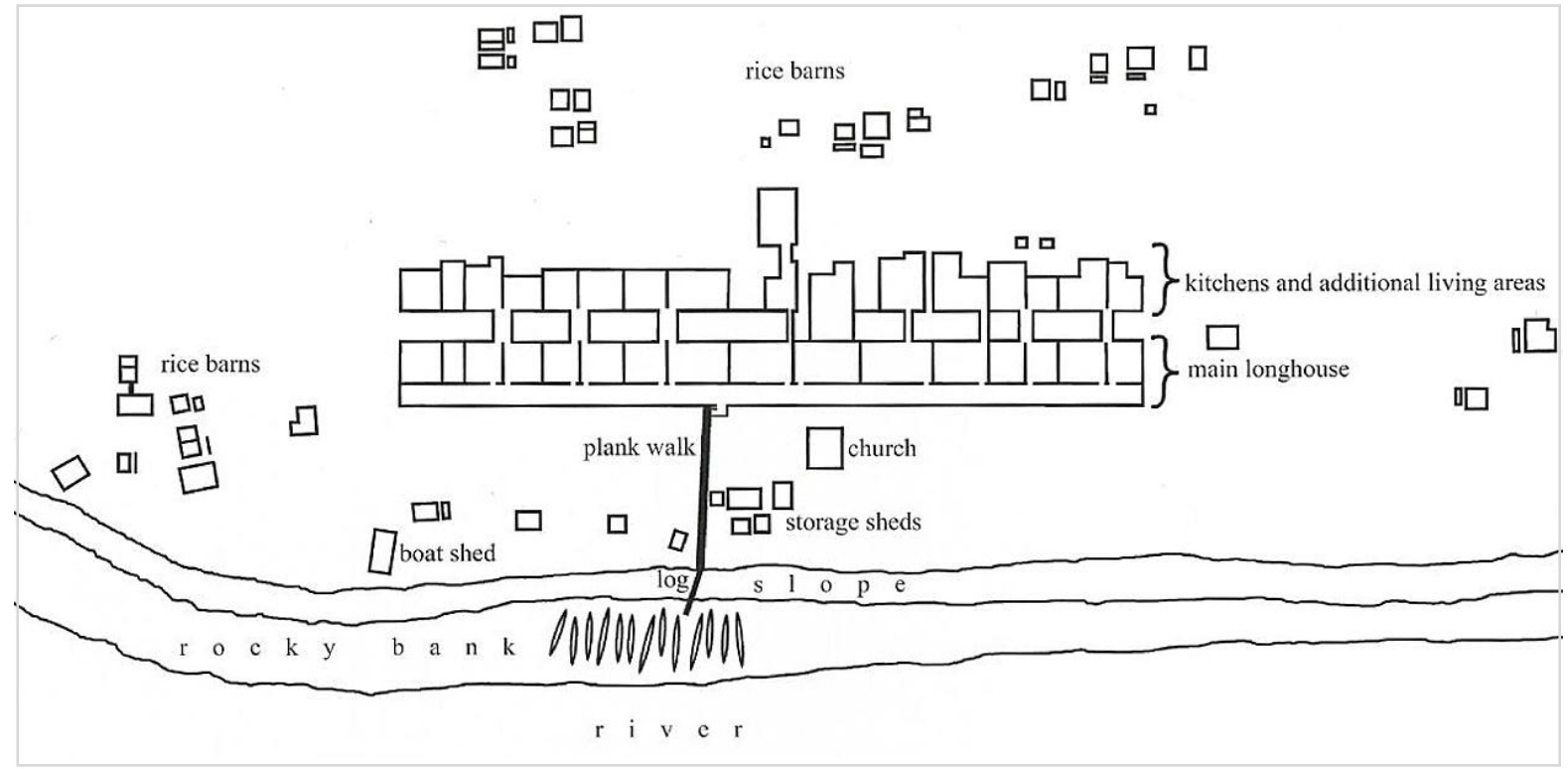

Fig. 3.24 Plan of a Kenyah (part of the Orang Ulu group) longhouse on the upper Baram River

${ }^{205}$ Winzeler The Architecture of Life and Death in Borneo p60 


\section{3) Tudor Revival}

At the turn of the twentieth century, many designs of recreational buildings in Malaysia sought to emulate the Tudor style, mimicking the revivalist romantic movement in Britain at the time. ${ }^{206} \mathrm{~A}$ notable example of the Tudor style can be seen in public buildings such as the Royal Selangor Club. The Selangor Club is a Tudor-styled structure which catered to the social and recreational needs (cricket and other sporting events) of the expanding expatriate community in Kuala Lumpur. However, membership to this elite club was primarily determined by high educational and social standards, rather than race or citizenship.

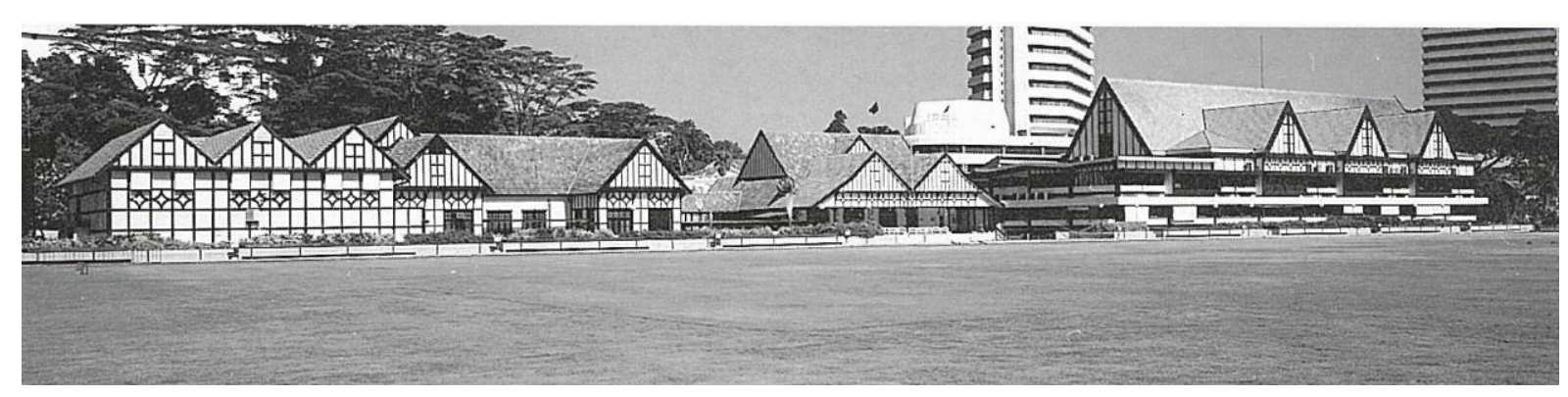

Fig. 3.25 The older portion of the Royal Selangor Club building (left and center) and the latest addition completed in 1979 (right)

The Kuala Lumpur based elite club, established in 1884, was initially a timber structure with a thatch roof and consisted of a clubhouse and a pavilion. ${ }^{207}$ The main club house is fondly known as 'The Spotted Dog', a nickname derived from the two Dalmatians owned by the wife of the Superintendant of the Selangor Police. ${ }^{208}$

In 1890 , the building was replaced by a bigger two-storey timber structure designed by A.C. Norman. The redesign portrayed a mock Tudor style. The character-defining features of the style, evident in the Royal Selangor Club, include the steeply-pitched and multi-gabled roofs with prominent frontfacing gables and decorative elements, such as: half-timbering, arches, textured wall surfaces, and tall narrow windows usually in clusters. ${ }^{209}$

\footnotetext{
${ }^{206}$ Chen 'Architecture' The Encyclopaedia of Malaysia p77

${ }^{207}$ Yeang The Architecture of Malaysia p65

${ }^{208}$ Royal Selangor Club "RSC Since 1884 the Humble Beginning" unpaginated

${ }^{209}$ City of Glendale California "Tudor Style" unpaginated
} 


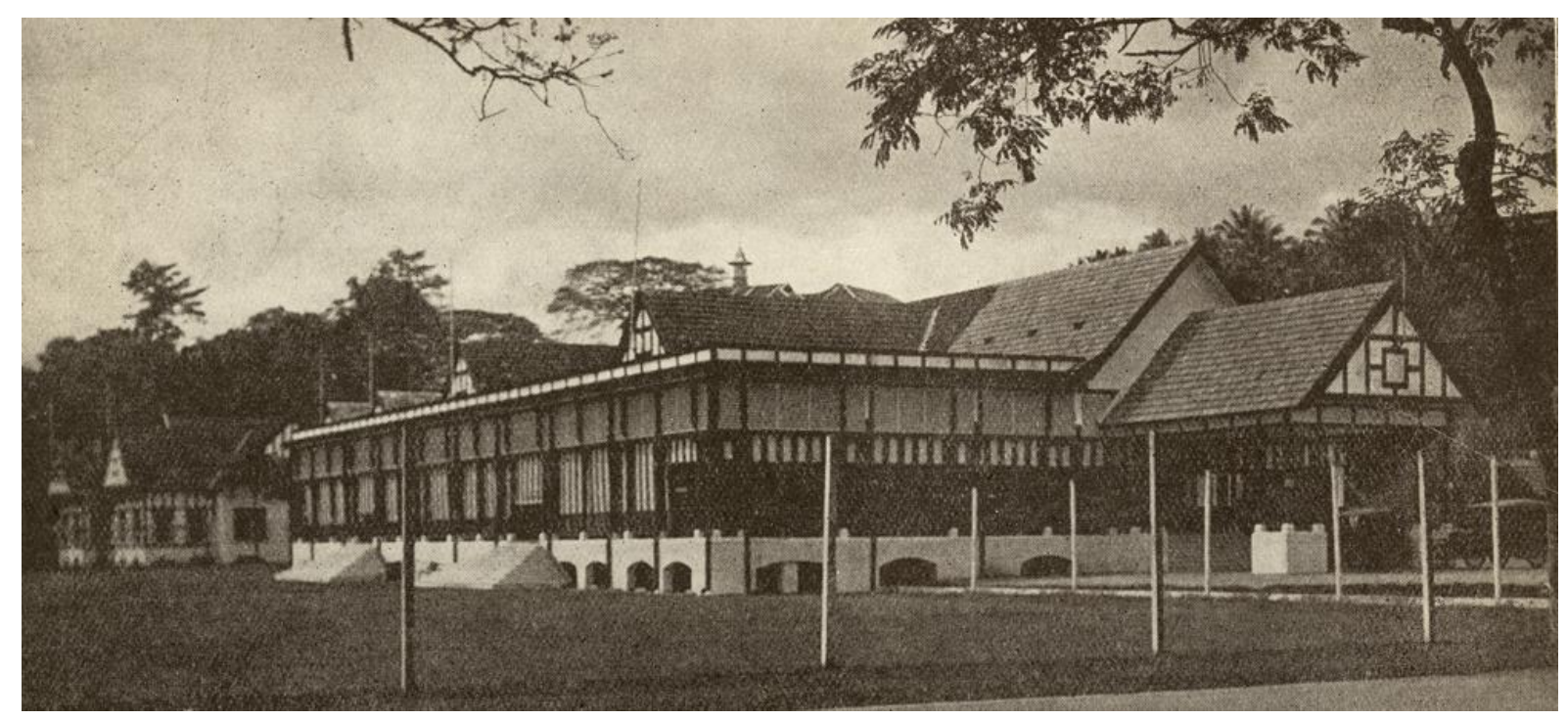

Fig. 3.26 The earlier Royal Selangor Club building (date unknown)

The timber posts were painted black and stood on concrete plinths to prevent rotting and termite attacks. The area was prone to flooding, prompting the newer building to be constructed six steps above ground level. The idea of elevating the building could very well be inspired by the construction of Malay houses, which are raised on stilts to provide protection from floods during the rainy season. The original building is said to be based on the configuration of an Anglo-Indian colonial bungalow which is an indigenous form of Bengal architecture. ${ }^{210}$ Bengal architecture was introduced to England by expatriates returning from India, and Yeang has speculated that Norman studied this style prior to his Malaya visit. ${ }^{211}$

In 1910, the club expanded to included extensions with a design similar to mock-Tudor houses and the removal of the second storey of the original building. The redesign was done by architect, Arthur Benison Hubback. More additions were made in 1922, keeping with the same designs. These two renovations gradually changed the shape of the building closer to a British Tudor gentry's house. ${ }^{212}$ In the late 1960s another extension was added. In 1970 the main section of the club was razed in a fire, prompting the most recent addition which was completed in 1979. The addition style was designed by local architect Fong Ying Leong.

\footnotetext{
${ }^{210}$ Yeang The Architecture of Malaysia p65

${ }^{211}$ Yeang The Architecture of Malaysia p65

${ }^{212}$ Yeang The Architecture of Malaysia 065

In the late 1960 another extension was added. In 1970 the main section of the club was razed in a fire, prompting the most recent addition which was completed in 1979. The style was designed by architect Fong Ying Leong.
} 
The colonial strategies included constructing full blown replicas of English houses to recreate the ambiance of a familiar and comforting place. ${ }^{213}$ The Royal Selangor Club might have been built in a Tudor style to capture the atmosphere, as well as convey the social connotations, of the elite Tudor country houses seen in Britain at the time. Tudor Revival country houses such as Ascott House in Birmingham, built eight years prior to its Selangor counterpart, could very well have served as a design precedent. Coincidentally, Ascott house was also known for holding cricket matches with the first match being played on the 28th August 1880, four years before the Royal Selangor Club was established. ${ }^{214}$

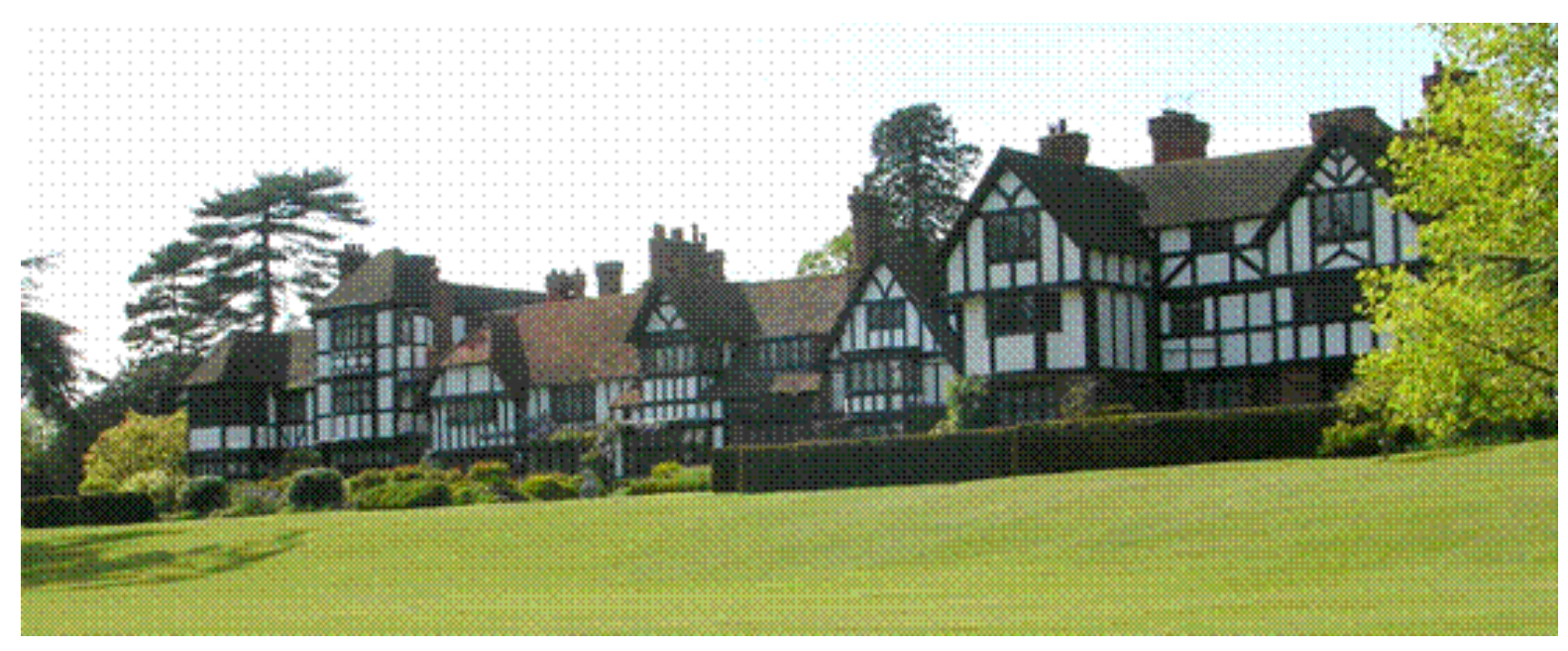

Fig. 3.27 The garden front of the Ascott House in Buckinghamshire, England.

Ascott House was originally a Jacobean half timbered farmhouse built in 1606 but it underwent numerous changes. ${ }^{215}$ The farmhouse was replaced by the gabled, mock-Tudor ranges added by the architect, George Devey. ${ }^{216}$ This expansion and extensive remodeling took place in 1876, when the house was purchased by Leopold de Rothschild, the great grandson of Baron Mayer de Rothschild. Grand Tudor country houses were inspired by a competitive determination to give visible proof of the owners' prosperity and social standing. ${ }^{217}$ The Tudor country house or manor house is historically associated with wealthy nobles and aristocrats.

The Royal Selangor Club is an elite club whose membership is based on wealth and status. This resembles the domestic architecture of the indigenous longhouses where membership to the

\footnotetext{
${ }^{213}$ Abel Architecture and Identity Responses to Cultural and Technological Change p166

${ }^{214}$ Ascott House "Cricket at Ascott" unpaginated

${ }^{215}$ Tour UK "Ascott House" unpaginated

${ }^{216}$ Tour UK "Ascott House" unpaginated

${ }^{217}$ Airs The Tudor and Jacobean Country House. A Building History p6
} 
community implied the acceptance of the decrees of the headman. ${ }^{218} \mathrm{~A}$ portion of the club also assumed similar functions of a men's house where entry was off limits to women. This gender segregation is also reminiscent of the organisation of the vernacular houses where certain spaces were primarily the men's domain (e.g the baruk). Women and children are still not allowed entry to the bar of the Royal Selangor Club to this day. ${ }^{219}$

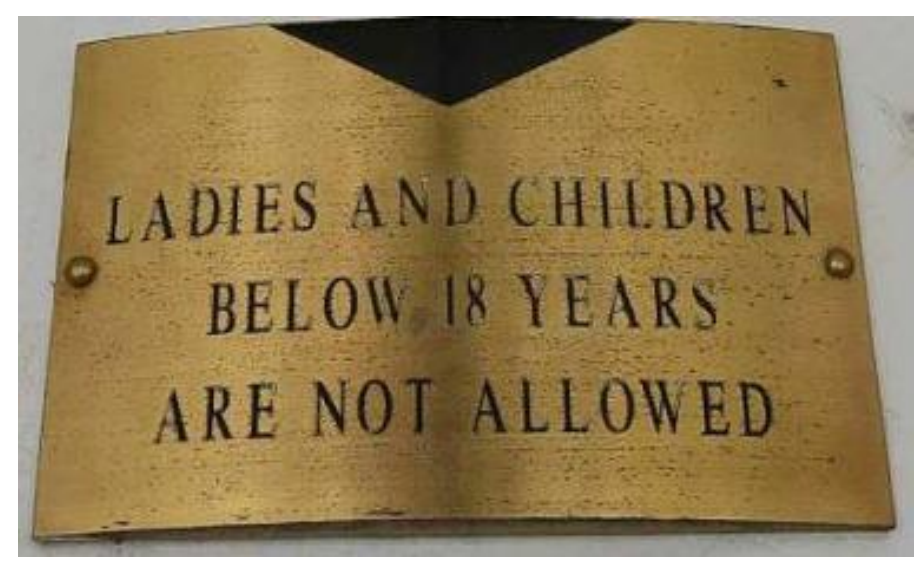

Fig. 3.28 The plaque shown on the entrance to the Long bar

\section{4) Neo Gothic}

The Neo Gothic style is demonstrated in religious buildings such as St. Mary's Cathedral (1894) and St. Andrew's Presbyterian Church (1902), both built during the British colonial period. This architectural style is also evident in residential buildings such as the Carcosa mansion. The name 'Carcosa' or 'dear object' is believed to have derived from a book entitled The King in Yellow by Robert Chambers. ${ }^{220}$ 'Carcosa' was the setting for this fictional drama.
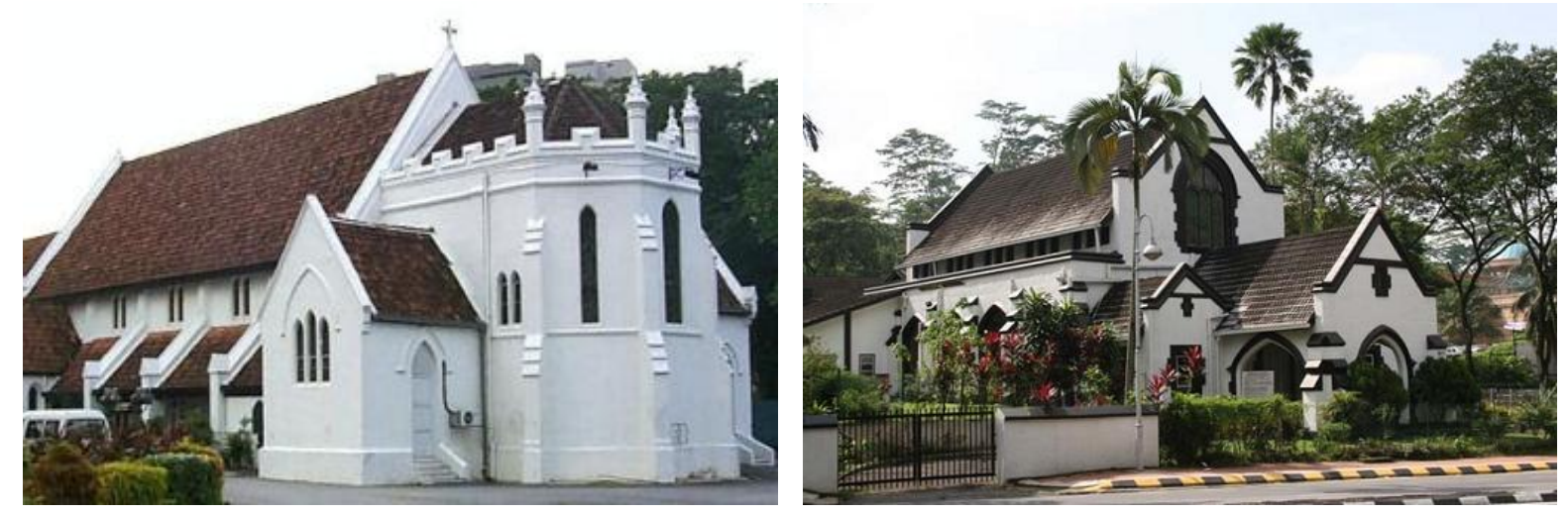

Fig. 3.29 St. Mary's Cathedral (1894) (left) and fig. 3.30 St. Andrew's Presbyterian Church (1902) (right)

\footnotetext{
${ }^{218}$ Oliver Dwellings p164

${ }^{219}$ Chan "So closely linked to birth of a nation" unpaginated

${ }^{220}$ Yeang The Architecture of Malaysia p67
} 


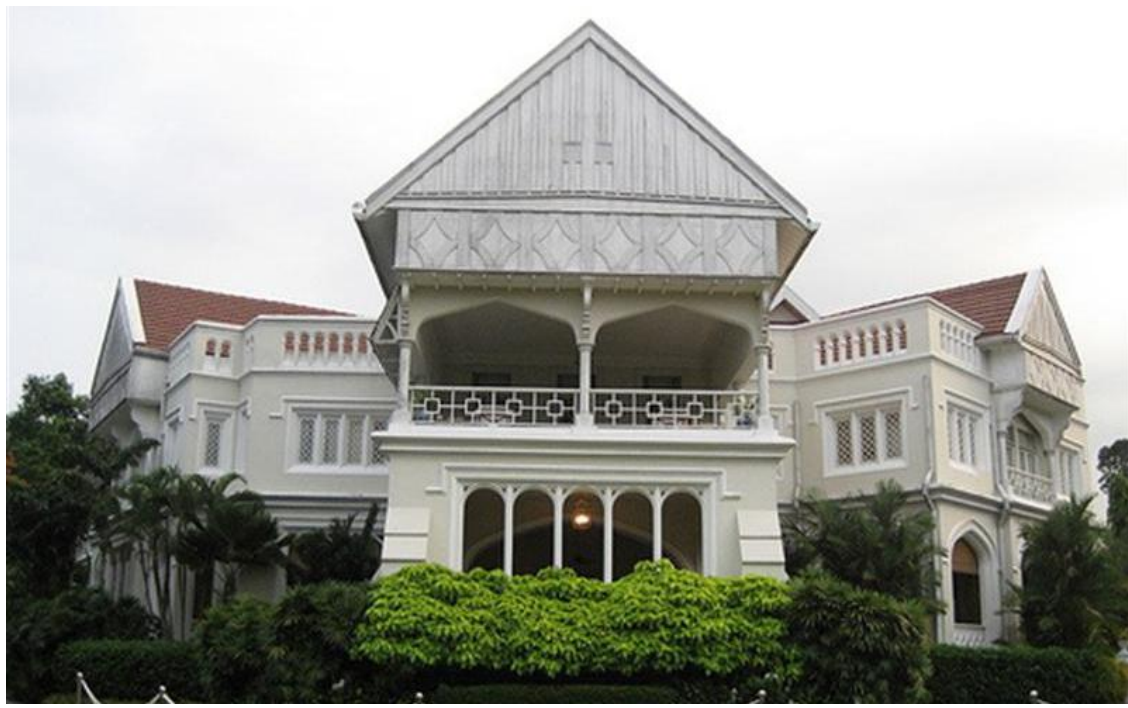

Fig. 3.31 The Carcosa

mansion (1987), Kuala

Lumpur

The Carcosa mansion was completed in 1897 and served as the official residence of Sir Frank Athelstane Swettenham upon his appointment as Resident General of the

Federal Malay States. The building was designed by A. C. Norman and under the supervision of the State Engineer of Selangor Charles Edwin Spooner. ${ }^{221}$

The mansion is situated on top of a hill, and was described as eclectic fusion of Neo-Gothic and Tudor styles. ${ }^{222}$ The residence consists of more than eight bedrooms and eleven bathrooms with all the bathrooms overlooking a balcony. The top floor consists of a small private sitting room and study, dressing rooms connecting to the master bedroom and a sitting room attached to a main guest room. ${ }^{223}$ The mansion is surrounded by 40 acres of meticulously manicured English gardens.
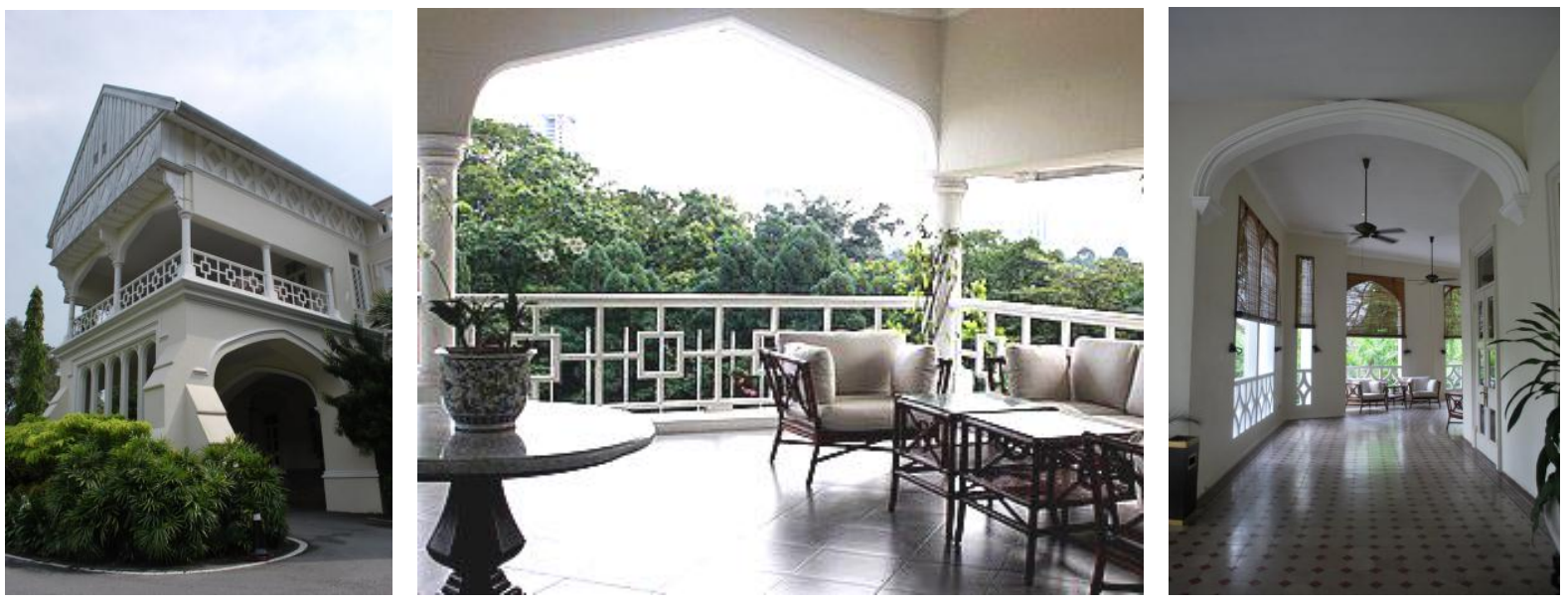

Fig. 3.32-3.34 The porch (left), verandah (centre) and drawing room (right)

\footnotetext{
${ }^{221}$ Yeang The Architecture of Malaysia p67

222 Malaysia Builder "Carcosa Seri Negara" unpaginated

${ }^{223}$ Yeang The Architecture of Malaysia p69
} 
In 1904, a guest palace was built adjacent to the site. The building, called the 'King's House', housed the Governor of the Straits Settlements as well as other illustrious guests of the Malay Federation. ${ }^{224}$ The British government vacated the premises and handed the Carcosa over to the Malaysian Government in 1987. At present, the two buildings are known as the Carcosa Seri Negara, a luxury hotel and a historic heritage landmark.

Although the design of the Carcosa mansion was influenced by Neo-Gothic and Tudor styles, it is evident that the architect had taken cues from the traditional Malay house form. The features include broad verandahs, high ceilings and full length windows with balustrades. Concessions to the tropical climate are also demonstrated through the introduction of a front porch to provide shelter and shade from the weather and verandahs, which surround both floors of the house, to ensure adequate ventilation. The emergence of detached residential buildings such as the Carcosa mansion in the country presented the local inhabitants with an alternate lifestyle which was more private and isolated from communal dwellings.

\section{Chapter Conclusion}

Heath has created a structural model (fig 3.35) that illustrates the dynamics that shape vernacular form in order to understand the local in global terms. Regional filters are a range of forces that act on a particular society, prompting regional building patterns, spatial adjustments and meaning. ${ }^{225}$ These forces include climatic, cultural, social, racial, historical, political, economic and religious factors, etc. Connecting the spheres of cultural conventions and influences to regional factors on the chart is the individual as conveyor of knowledge and as an agent of change. This overlapping produces either idiosyncratic, vernacular or transplanted forms. Idiosyncratic forms are buildings within a particular locale that is limited to a personal gesture or belief, often considered eccentric works by visionaries. ${ }^{226}$ Buildings that are conceived as vernacular forms are regionally distinct and are culturally syncretic. ${ }^{227}$ Transplanted forms are buildings that respond little to pronounced regional dynamics except in minor ways that are inevitable and remain the original set of ideas that governed them prior to their arrival in the region. ${ }^{228}$

\footnotetext{
${ }^{224}$ Saujana Hotels \& Resorts "Carcosa Seri Negara” unpaginated

${ }^{225}$ Heath Vernacular Architecture and Regional Design: Cultural Process and Environmental Response p9

${ }^{226}$ Heath Vernacular Architecture and Regional Design: Cultural Process and Environmental Response p9

${ }^{227}$ Heath Vernacular Architecture and Regional Design: Cultural Process and Environmental Response $p 9$

${ }^{228}$ Heath Vernacular Architecture and Regional Design: Cultural Process and Environmental Response p9
} 


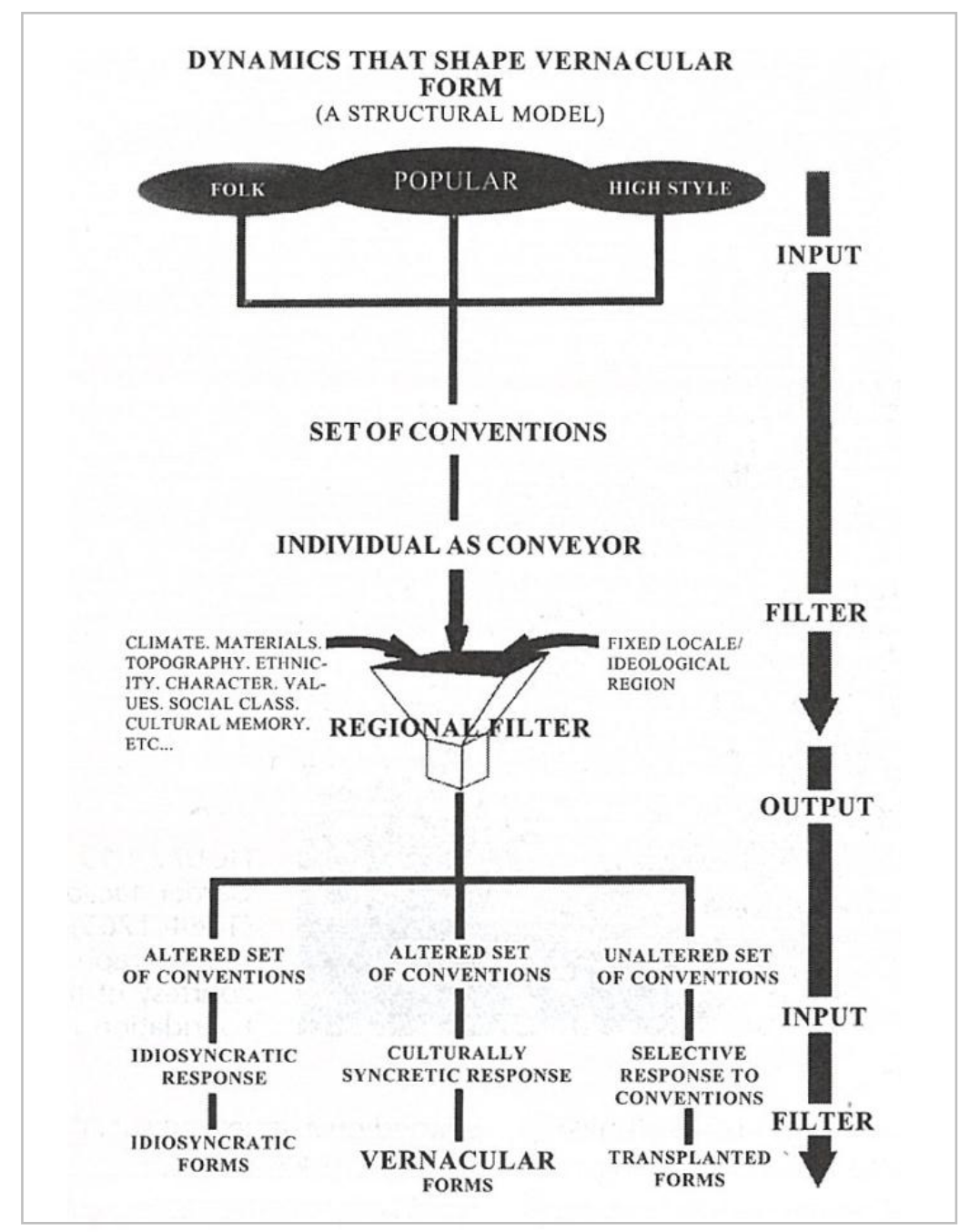

Fig. 3.35 A three dimensional exchange model, 'Dynamics that shape vernacular form'

The architecture of the Chinese immigrants falls in the category of vernacular forms. Although they found comfort in maintaining many of their own homeland traditions, as reflected in their domestic architecture, they embraced the architectural changes that were introduced either subtlety or drastically by external influences. The combination of local and imported materials as well as traditional and foreign forms generated new architectural styles such as the Straits Eclectic Style and the Anglo-Straits Eclectic Style.

While these changes may initially cause conflict with traditional practices, eventually they are likely to be embraced as traditions themselves. This is evidently true as reflected in the architecture of the Chinese which writers, such as Fels ${ }^{229}$, have established and labeled part of Malaysia's vernacular

\footnotetext{
${ }^{229}$ Fels "Conserving the Shophouse City" p6 Patricia Tusa Fels is an architect, historic preservationist and writer who had a particular interest in vernacular buildings and historic enclaves in Penang. In her paper entitled "Conserving the Shophouse City", she described the Malaysian shophouse as a marvel of vernacular architecture.
} 
architecture. Buildings such as the shophouse are still presently being constructed and remain an integral way of life in Malaysia, housing small-scale workplaces, businesses, shops, hotels, cafes and residences. $^{230}$

However, this is different in the case of some colonial structures which are seen as transplanted forms. Colonial rulers constructed replicas of buildings reminiscent of the ones found in their homeland in order to impress local inhabitants with their foreign culture and lifestyle. Structures such as the Portuguese's A Famosa fort, Dutch's Stadhuys and the Christ Church do not demonstrate many attempts to engage with their new context. These building types were reproductions and constructed to serve the main intentions of the colonial rulers (forts as defensive purposes, Stadhuys to house administrators and churches to spread religion).

The British colonial rule led to the introduction of new architectural styles as well as building types such as the railway stations, recreational clubs and monumental administrative buildings. The examples presented in the chapter demonstrated the gradual responses to regional dynamics as the buildings incorporate the synthesis between foreign and traditional ideas.

Although it seemed that there was no conceivable local parallel to such new building types, this can only be referred to their physical forms. Glassie states that in mixing of the old and new, all buildings are to some extent vernacular. ${ }^{231}$ No matter how revolutionary the creation, no building can be described as entirely new. There must be some hint of the common and traditional, otherwise a building would be deemed incomprehensible. ${ }^{232}$ As Oliver described:

\footnotetext{
The vernacular is local and distinctive, and in its distinctiveness, it is congruent with place. This quality of the vernacular allows the local population to identify themselves in relation to a place and to the history of the place. For the vernacular in its epistemological aspects transmit knowledge of a type of local history, the history of the human interaction with a particular environment. ${ }^{233}$
}

These new building types created new forms of spatial arrangement and social order but have an existing parallel that assisted the local inhabitants in understanding their use and purpose. When the people within a region embrace aspects of a unique building response, in a collective and consistent manner, the building becomes culturally syncretic. It becomes vernacular.

\footnotetext{
${ }^{230}$ Fels "Conserving the Shophouse City" p3

${ }^{231}$ Glassie Material Culture p275

${ }^{232}$ Schneider-John Vernacularisation in Architecture p65

${ }^{233}$ Huppauf and Umbach Vernacular Modernism p176
} 


\section{Chapter 4: Foreign Influenced Architecture Part II (1795-1957)}

The previous chapter investigated the shift between colonial buildings that expressed the colonial ruler's individual ideas and had little regard for contextual issues. It was during the rule of the British Empire that colonial buildings started to respond to regional dynamics.

The British colonial rule made the most significant impact on Malaysian architecture, than the Dutch and the Portuguese. Various architectural styles were introduced to the region, which included Moorish influences, Tudor Revival, Neo- Classical and the Neo Gothic style, as well as detached building types, like the colonial bungalows and villas. Although they brought their homeland traditions, the British settlers to the country were also willing to converge, compromise and adapt, particularly to suit the tropical climate. This chapter focuses on the architecture of the detached residences that emerged during the British colonial rule, which underwent relocation, transformations and modifications as well as cultural exchanges to adapt to the new environment.

\section{The Emergence of Detached Houses}

Earlier British administrators resided in Malay house replicas, described as timber constructed buildings on piles with a steep thatched roof and a covered verandah in front and sometimes around the house. ${ }^{234}$ Chinese roofing tiles were then introduced to replace the flammable thatch. As these tiles could not keep the house as cool as the former material, the Chinese developed the 'jack-roof' to increase wind circulation and improve ventilation in the house. This design consists of the roof being divided into two sections, with the higher section overlapping the lower one. ${ }^{235}$

The transformation of the simple Malay house extended to include the change of building materials to brick, tiles and stucco as well as the insertion of classical elements such as Roman columns and other western ornamentation. During the British administration, Malaya reflected the Palladian style of Georgian architecture which was a prevailing trend in England from the sixteenth to nineteenth centuries. ${ }^{236}$ This style utilized symmetrical planning, harmonious proportions, and Greek and Roman motifs. ${ }^{237}$ This style, intended to symbolise distinction, grandeur and authority, was widely imitated by colonial architects for the design of country houses, government and administrative buildings. However, as there was a shortage of experienced architects in Malaya, these models were reproduced as best as they could to resemble their originals.

\footnotetext{
${ }^{234}$ Yeang The Architecture of Malaysia p146

${ }^{235}$ Yeang The Architecture of Malaysia p146

${ }^{236}$ Yeang The Architecture of Malaysia p144

${ }^{237}$ Chan Post-Merdeka Architecture Malaysia 1957-1987 p15
} 
A less conscious consequence of foreign influences was the awareness and introduction of an alternative and more appealing lifestyle. Lifestyle changes led to the shift from communal dwellings to detached houses such as the bungalow, villas and mansions, the increased importance of privacy, as well as the adoption of material belongings to express status and wealth. Throughout the colonial period, these foreign inspired buildings were commissioned and owned by local and wealthy businessmen. As houses articulated relationships between social groups, more often than not, these men sought to emulate Western architecture with the impression that these foreign styles were the ultimate representations of the elite.

\section{The Bungalow}

The word 'bungalow' originated in seventeenth century Bengal, and derived from the word bangala or indigenous hut. ${ }^{238}$ This peasant dwelling was a mud-walled structure raised a foot or two above the ground, enclosed by a verandah and with a roof curved at the ridge. ${ }^{239}$ When the idea and term were transferred from India to England in the second half of the nineteenth century, the bungalow adopted a different definition. The European definition bore no relationship to the conception and construction of the original bangglo term, describing instead the bungalow as "a separate or detached dwelling, sometimes with a verandah, generally occupied by one household or family and located on its own plot." 240

Throughout the nineteenth century, the emergence of the bungalow flourished on the outskirts of Malaysia's towns. ${ }^{241}$ There are two main types of hybrid bungalows in Malaysia, the Anglo-Indian bungalow and the Anglo-Straits Eclectic Style bungalow. The Anglo-Straits Eclectic Style comprises the architectural styles of the Anglo-Indian, Straits Eclectic and Malay.

\section{The Anglo-Indian Bungalow}

In Malaysia, the bungalow typology was popularized by the British. The Anglo-Indian bungalow house style is a fusion of European and Asian building traditions and was introduced by European settlers in the eighteenth century. Colonial administrators, British merchants and planters transported this house style to Malaysia at the time when Penang was established as an outpost of the East India Company in $1786 .{ }^{242}$

\footnotetext{
${ }^{238}$ Ahmad, A. Ghafar "The Architectural Style of The Peranakan Cina" unpaginated

${ }^{239}$ Ahmad, A. Ghafar "The Architectural Style of The Peranakan Cina" unpaginated

${ }^{240}$ King The Bungalow The Production of a Global Culture p2

${ }^{241}$ Chen 'Architecture' The Encyclopaedia of Malaysia p94

${ }^{242}$ Chen 'Architecture' The Encyclopaedia of Malaysia p94
} 


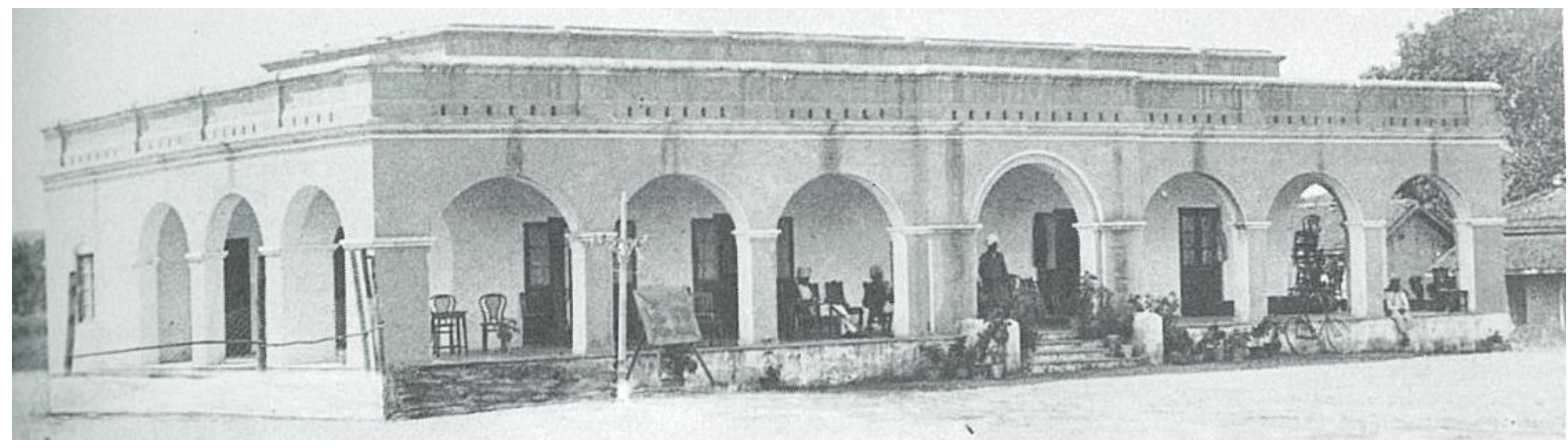

Fig. 4.1 A bungalow in India, constructed by the British in the 1860 s, with a raised central hall and windows at ceiling height which acknowledged the tropical climate

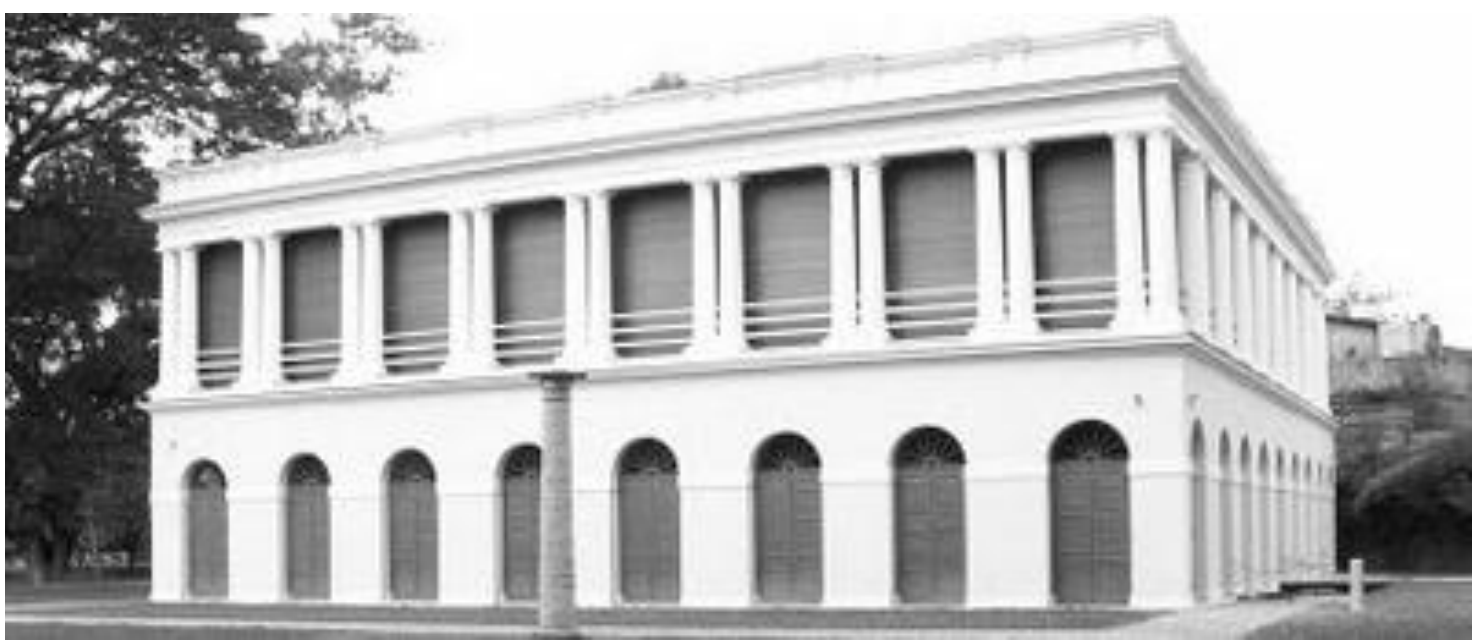

Fig. 4.2 Suffolk House, Penang built in 1790 and restored to its former glory in 2000

Suffolk house (1790) (fig. 4.2) is one of the few remaining Anglo-Indian bungalows in Malaysia. The house, located in Georgetown, Penang, was originally the residence of Captain Francis Light, the founder of the British Settlement of Penang. Suffolk House has undergone many transformations, evolving from a simple colonnaded Anglo-Indian garden house to a detached double-storey building of grand proportions. The house, an example of classic Georgian architecture, stands as a surviving hybrid model of the local Malay house and the colonial Anglo-Indian mansion. The building was symmetrically planned, which is typical of a late Georgian house, a style prevalent during the reigns of English kings, George I, II and III (1718-1820). ${ }^{243}$ The design of Suffolk House took into consideration the local climate by adopting verandahs, deep eaves, large hipped high roof and full length windows with balustrades. The original house had a flat roof made of Indian floor tiles

${ }^{243}$ Chen 'Architecture' The Encyclopaedia of Malaysia p94 
bordered by a low parapet but it was replaced by a hipped pan-tile roof in the nineteenth century as it was more suitable to the climate. ${ }^{244}$

The building is held up by a total of 78 columns that run along the verandah and the front and rear of the interiors. The ground floor is surrounded by walls with a series of arched openings, and is primarily supported by the outer and inner walls of the building. Wooden beams support the first floor and roof.

\section{Anglo-Straits Eclectic Style Bungalows}

The bungalows constructed in the late nineteenth and early twentieth centuries were a fusion of architectural styles of the Anglo-Indian, Straits Eclectic and Malay. The Syed Alatas Mansion is a notable example of a double storey bungalow that incorporated a hybrid fusion of European, Indian and Malay cultural influences.
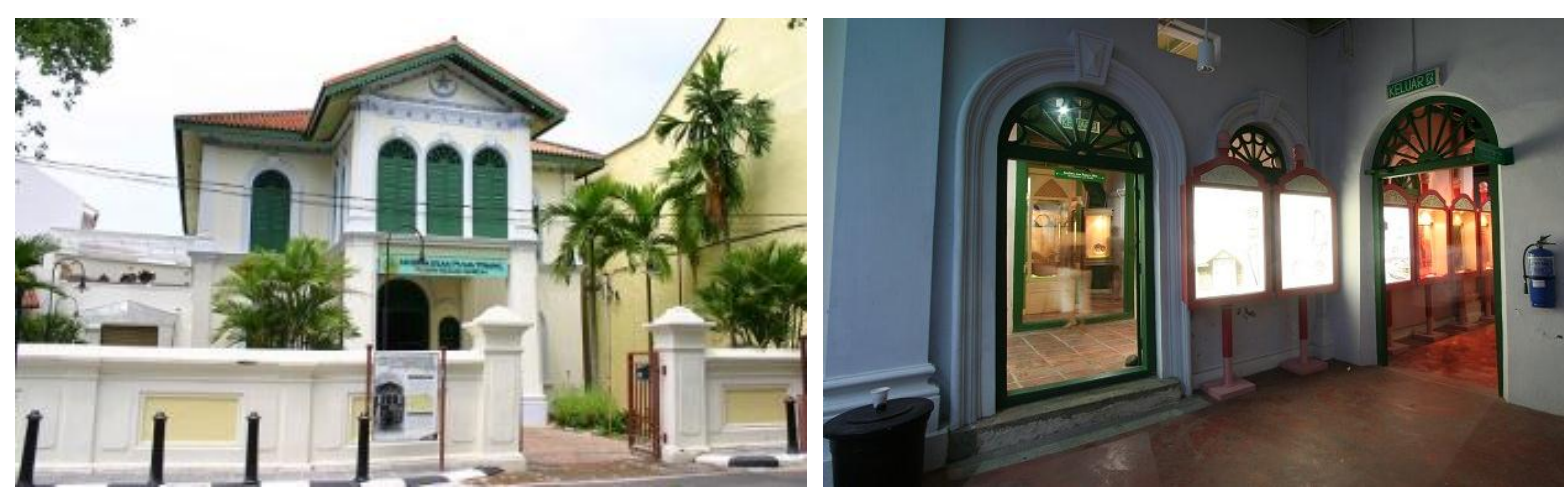

Fig. 4.3 and fig. 4.4 the Syed Alatas Mansion, Penang

The mansion belonged to Syed Mohd Alatas, a wealthy Achehnese merchant of Arab descent. It is a masonry building of brick and lime mortar construction. The plan of the building is symmetrical and is identical on the ground and first floors. The building is fronted by a porte cochere with a room on top, and covered by a terra cotta pan-tile hipped roof with gable roof over the carriage porch. ${ }^{245}$ The porte-cochere was a popular feature during the early Victorian period of the 1840s. The internal rooms were contained by brick walls which were adorned with moulded architraves, also suggesting a mid-Victorian influence. Its timber floors, raised on brick piers, panelled doors and full-length shutters with fanlight are inspired by the construction of the traditional Malay house. The façade

\footnotetext{
${ }^{244}$ Chen 'Architecture' The Encyclopaedia of Malaysia p94

245 Ahmad "Syed Alatas Mansion" unpaginated
} 
displays stucco arabesque embellishments, moulded architraves, cornices and pilasters formed by lime plaster. The eaves are fringed with dentilated fascia boards.

Transplanting such bungalows from India into Malaysia's complex colonial heritage has entailed further evolution. The attempts to reconcile indigenous forms of the Malay house with European and Indian influences led to hybrid designs. Colonial domestic architecture such as the bungalows have become so common and widespread so as to constitute a regional vernacular.

\section{$\underline{\text { The Bok House }}$}

During the late nineteenth century and beginning of the twentieth century, numerous Palladian styled villas emerged in Malaysia. These houses were mainly owned by wealthy Chinese businessmen who were influenced by the architectural style while spending time in Europe. This style was widely used in English colonies, including Malaysia, and was regarded as the "epitome of civilised society". ${ }^{246}$
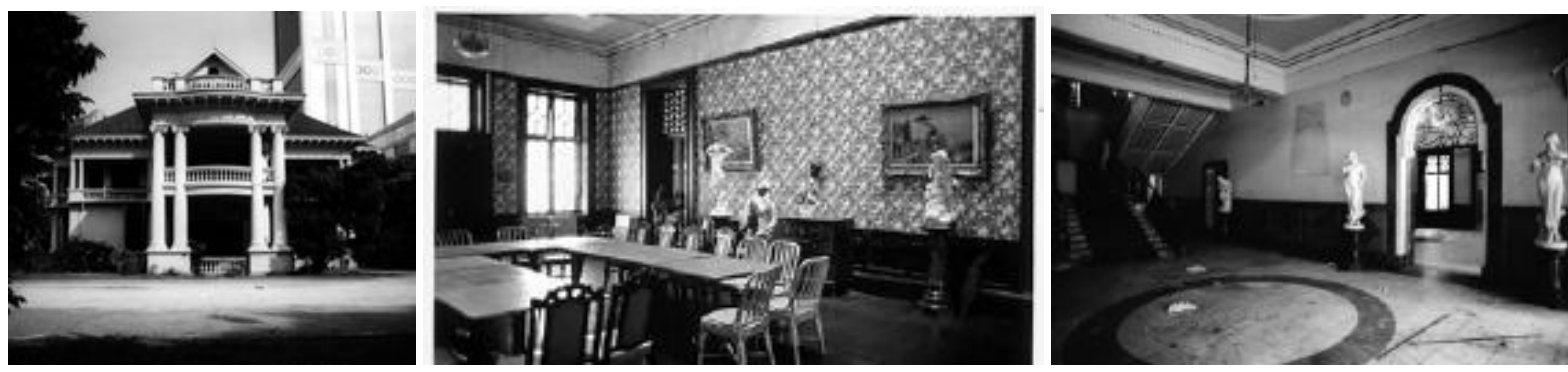

Fig. 4.5- fig 4.7 The elevation of the Bok House, Kuala Lumpur (1929) (left), dining room (centre) and the foyer (right)

The famous Bok House (1929) (fig. 4.5), was a perfect example of an intercultural exchange between the East and the West. ${ }^{247}$ Located on 121 Ampang Road, in the city of Kuala Lumpur, the Bok House was commissioned by Mr Chua Cheng Bok, a successful entrepreneur. ${ }^{248}$ This distinguished landmark

\footnotetext{
${ }^{246}$ Ho, Hasan, and Noordin "An Influence Of Colonial Architecture To Building Styles And Motifs In Colonial Cities In Malaysia" unpaginated

${ }^{247}$ The building served as the residential house of Chua Cheng Bok and his family. However, the house underwent colourful transitions over the years of its existence. During the Japanese Occupation of Malaya, Bok House was occupied by the Yokohama Specie Bank. After WWII, it served as boarding house. In 1958, it was known as Le Coq d'Or Restaurant, one of the city's finest restaurants. The restaurant operated for 48 years until it was closed in 2001.

${ }^{248}$ Cardoza "Bok House a window into the world that was" New Straits Times, Jul 92006.
} 
was designed by Swan \& MacLaren, one of the leading colonial architectural and engineering firms at the time. ${ }^{249}$

The Bok House was celebrated for its architectural splendor and style. Chua Cheng Bok commissioned the design of the house in the style of the civic buildings that he saw on a visit to England. ${ }^{250}$ The building was considered to be an outstanding model of how Classical European planning could be adapted to Malaysia's tropical climate. ${ }^{251}$ The Bok House demonstrated the planning design of the Palladian style of Renaissance revivalism with a hint of Baroque influence while also accommodating the demands of the tropical climate through its arrangements of balconies and verandahs. The balconies and verandahs skirt both floors, protecting the external walls from direct solar heat while the interior is kept cool by the free circulation of air. ${ }^{252}$ These are the same principles of a Malay house which are to expose as many external surfaces as possible to the movement of air, usually with floor to roof window apertures. The pitch of the roof is steep to allow water drainage during rainfall while the balustrade on the roof peak hides the skylight that allows natural sunlight to penetrate through to the hall on the upper floor.

According to Yeang, the house follows the plan of the Palladian villa, with the dominant feature being its symmetry, abundance of columns and other classical elements. ${ }^{253}$ The subtle curves on the portico, ornateness of the gate and grand central stairs reflect a Baroque influence. ${ }^{254}$ This adaptation to the tropical climate of the country was a result of the interaction between imported cultures and the vernacular architecture. This includes the projecting and covered verandah and anjung (porte cochere), the use of a selang (walkway) which joined the rumah ibu (front house) with the smaller family house at the rumah dapur (rear). ${ }^{255}$ The interiors were adorned with exquisite detailing, Marseille tiles, marble flooring, panelling, chandeliers, windows, furniture and decorations. ${ }^{256}$ European art and stained glass were displayed alongside Chinese mother-of-pearl furniture and Peranakan tiles.

\footnotetext{
${ }^{249}$ Ong "Swan and Maclaren" unpaginated Swan and MacLaren Architects was a British architectural firm based in Singapore. Two engineers, Archibald Swan and Alfred Lermit, started Swan \& Lermit, but the partnership ended in 1890. In 1892, another engineer, James Waddell Boy Maclaren, joined as a partner and the firm was renamed Swan \& Maclaren.

${ }^{250}$ Hamid "Message from the President" unpaginated

${ }^{251}$ Yeang The Architecture of Malaysia p161

${ }^{252}$ Yeang The Architecture of Malaysia p161

${ }^{253}$ Yeang The Architecture of Malaysia p161

${ }^{254}$ Hamid "Message from the President" unpaginated

255 "Bok House a window into the world that was" New Straits Times, Jul 9 2006:22

256 "Bok House a window into the world that was" New Straits Times, Jul 9 2006:22
} 
In 1958, the Bok House was turned into a restaurant, named Le Coq d'Or, which was at that time arguably Kuala Lumpur's finest restaurant. ${ }^{257}$ The rear section of the house was demolished in 1999 followed by the closing down of the restaurant in 2001. The gradually deteriorating Bok House resulted in its complete obliteration recently in December 2006, much to the dismay of the public.

\section{The Loke Yew Mansion}

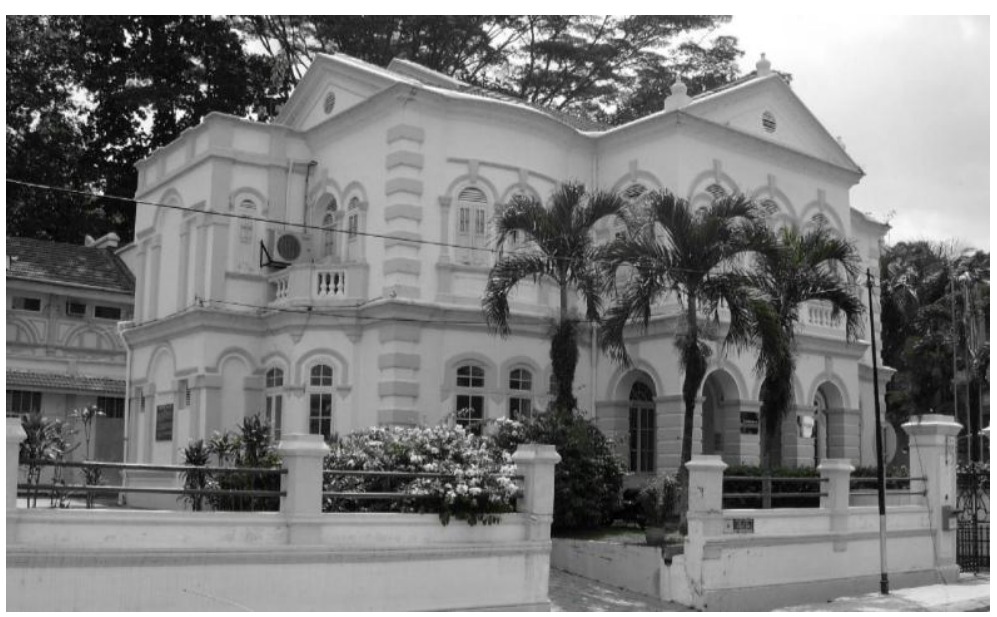

Fig. 4.8 The Loke Yew Mansion, Kuala Lumpur

The Chinese towkay mansion was regarded as the ultimate status symbol because these mansions, more often than not, tell the ragsto-riches story of how a penniless labourer became a wealthy master.

Wealth and ambition led them out of their shophouses and into life in detached houses. ${ }^{258}$ Symbolising par excellence, these mansions are known for their ostentatiousness and splendor. Built in the late nineteenth and early twentieth centuries, these private residences usually reflect the owners' double allegiance to the East and West, combining European classical forms and styles with traditional house plans and motifs. ${ }^{259}$ Chen has written that it was essentially the Anglo-Indian detached bungalow and the decorative qualities of the late Victorian architecture in England, which inspired the emergence of ornamental houses in the British Strait Settlement. ${ }^{260}$

The Loke Yew Mansion ${ }^{261}$ is a building that demonstrated these Western and Oriental design principles. The mansion, built in 1862 , is believed to be the first brick residence and the oldest towkay (master) mansion in Kuala Lumpur. ${ }^{262}$ Philanthropist, Loke Yew, bought the modest house in 1892 and modified it over a period of twelve years with the help of both Chinese and European

\footnotetext{
257 "Bok House a window into the world that was" New Straits Times, Jul 9 2006:22

${ }^{258}$ Chen 'Architecture' The Encyclopaedia of Malaysia p96

${ }^{259}$ Chen 'Architecture' The Encyclopaedia of Malaysia p96

${ }^{260}$ Chen 'Architecture' The Encyclopaedia of Malaysia p96

${ }^{261}$ The house is currently an art and antique gallery known as 'The Artiquarium'.

${ }^{262}$ Yeang The Architecture of Malaysia p73
} 
craftsmen. ${ }^{263}$ The result was a mansion reminiscent of a European-style villa that followed a symmetrical design with a central entrance doorway leading to an inner two-storey courtyard. ${ }^{264}$

The front facade displays Chinese-style ventilators, Chinese door and window arrangements juxtaposed against Greek pediments and roof-top parapets as well as two flamboyant Dutch-styled gables. The entrance to the upper floor is located under an arcaded loggia of load-bearing Tuscan columns. ${ }^{265}$ The exterior and interior of the mansion are decorated with Chinese murals, Chinese figures and sculptured relief. The floors, doors and posts were made out of local Chengal timber while the upper and lower verandahs were paved with specially imported Chinese tiles. ${ }^{266}$

The fusion of foreign and local ideas has provided Malaysia with a modified version of the Malay house. The louvered verandah and walls replaced the ornate serambi balustrade, the squat Palladian proportion replaced the high raised platforms and the hipped gable roof replaced the ventilation openings.

\section{Chapter Conclusion}

Architectural forms are not immutable. There has never been a remotely 'pure' architecture in its origins and all buildings owe their features and qualities to multiple sources of forms. ${ }^{267}$ Abel, for example, drew upon the example of the Palladian villas that emerged in the suburbs of Georgetown, Penang from the eighteenth century. These large houses often served as residences to British colonists. The basic form of the house is unmistakably recognized as a Palladian 'villa suburbana', a building type and architectural style valued by the Europeans. ${ }^{268}$ The comforting ambiance of England was recreated and the familiar environment was duplicated. However, the exact model could not be relocated from a temperate to a tropical climate without undergoing some alterations. Upon closer inspection, this South East Asian model is very different from its European counterpart. In his writing, Abel compares a particular colonial villa found in Georgetown with the Villa Cornaro in Piombino Dese, Italy to illustrate the adaptations to a change in environment. The Villa Cornaro has a two storey portico with open colonnades. The upper storey of the Georgetown model was replaced with a habitable living space. A porticoed front porch was also added to encourage the

\footnotetext{
${ }^{263}$ Chen 'Architecture' The Encyclopaedia of Malaysia p96

${ }^{264} \mathrm{Ho}$, Hasan, and Noordin "An Influence of Colonial Architecture to Building Styles and Motifs in Colonial Cities in Malaysia" unpaginated

${ }^{265}$ Yeang The Architecture of Malaysia p73

${ }^{266}$ Cooper "Loke Mansion" unpaginated

${ }^{267}$ Abel Architecture and Identity Responses to Cultural and Technological Change p152

${ }^{268}$ Abel Architecture and Identity Responses to Cultural and Technological Change p153
} 
circulation of air and to provide shelter from carriage (now automobile) to the front entrance. Abel suggested that the colonists had taken cues from the principles of the Malay house which exposed as many external surfaces as possible to the movement of air, opening up those surfaces as far as possible with floor to roof window apertures. ${ }^{269}$

The English builders saw something in the Malay house of value without compromising the integrity of the forms or sacrificing bodily comfort or aesthetic taste. Although the intention was to mimic a particular style, these buildings were clearly different from their original and purer antecedent models. These buildings can be categorised as vernacular forms. Heath contends that the reworking of pre-existing elements, which have been transplanted from elsewhere and are adapted to a new environment and new social circumstances, results in a vernacular resource. ${ }^{270} \mathrm{He}$ compares this to the Darwinian Theory which speaks of forms that may be culturally and/or environmentally preadapted to a new setting. ${ }^{271}$

Sayyad also argues that all cultural experiences are hybridized and that all vernacular forms are transitional. ${ }^{272}$ He contends that while hybridized cultural expressions are the norm, particularly among colonized cultures, there are discernible patterns of human adjustment within these hybridized identities that define regional and sub regional distinctiveness. ${ }^{273}$ These patterns of human adjustment are clearly demonstrated through the innovative application and exploration of foreign and local styles to produce successful hybrid architecture.

\footnotetext{
${ }^{269}$ Abel Architecture and Identity Responses to Cultural and Technological Change p154

${ }^{270}$ Heath Vernacular Architecture and Regional Design: Cultural Process and Environmental Response p12

${ }^{271}$ Heath Vernacular Architecture and Regional Design: Cultural Process and Environmental Response p12

272 Upton "'Authentic' Anxieties" p300

273 Upton “'Authentic' Anxieties” p300
} 


\section{Chapter 5: Contemporary Malaysian Architecture (1957-present)}

With the advent of the International Style, the architecture of Malaysia was greatly influenced by Modernist architects such as Le Corbusier, Frank Lloyd Wright, Mies van der Rohe, Gerrit Rietveld and Walter Gropius. ${ }^{274}$ The return of freshly graduated scholars from their education abroad contributed to the spread of modern architecture in the country. Western architecture had set many precedents in design and technological innovation in the country. The anxious need to keep up with the rapid growth of the country's economy and population, did not allow local architects the luxury of time to experiment. During the 1970s, Malaysian architects started to question the validity of international models in the country. ${ }^{275}$

This chapter investigates the architectural consequences of Modernism and the International Style upon its introduction to Malaysia and the contribution of initiatives such as the Colombo Plan. Through case studies of contemporary buildings (e.g. Parliament House (1963) in Kuala Lumpur, Muzium Negara (National Museum) (1963) in Kuala Lumpur, Bank Negara (National Bank) (1983) in Kedah and Lembaga Tabung Haji (Pilgrim's Fund) (1984) in Kuala Lumpur), the chapter identifies the eclectic attempts, as well as more oblique approaches, to revive and capture the qualities of traditional architecture and determine at what point a work crosses the vernacular threshold to become regionally expressive.

\section{Education}

By the end of the 1950s, almost all architects in the country were trained in Western countries. ${ }^{276}$ They were mainly graduates from institutions in England and Australia. ${ }^{277}$ The first higher learning institution to offer an architectural degree in Malaysia was the Universiti Teknologi Malaysia (Malaysian University of Technology) which was only established in 1970 in Johor. ${ }^{278}$ In his research on Malaysian students' perceptions of overseas study destinations, Lawley concluded that most Malaysian students chose to study abroad in countries such as the United Kingdom, Australia, Canada, the United States and New Zealand, because the standard and quality of education was generally higher and better recognised by local employers. ${ }^{279}$ Initiatives such as the Colombo Plan

\footnotetext{
${ }^{274}$ Ismail Houses in Malaysia. Fusion of the East and the West p46

${ }^{275}$ Yeang The Architecture of Malaysia p273

${ }^{276}$ Chin "Towards a National Identity in Architecture" p21

277 Ismail Houses in Malaysia. Fusion of the East and the West p48

${ }^{278}$ University of Technology "About the Faculty" unpaginated

${ }^{279}$ Lawley and Perry "Thai and Malaysian students' perceptions of overseas study destinations: An Exploratory Study" unpaginated
} 
presented local students with opportunities to live and study abroad and produced architectural scholars who were keen on demonstrating their newly acquired skills and capabilities.

\section{The Colombo Plan}

The Colombo Plan is a regional organisation that aims to strengthen the economic and social development of member countries in the Asia-Pacific Region. This post-colonial initiative was conceived in January 1950 in Colombo, Sri Lanka and began operations on 1 July 1951. The original signatories of the Colombo Plan were seven members of the British Commonwealth. They comprised Australia, Canada, Sri Lanka (then Ceylon), India, New Zealand, Pakistan and the United Kingdom. In 1954, its membership expanded to include Burma, Cambodia, Indonesia, Japan, Laos, the Philippines, the United States, Thailand and Malaya. ${ }^{280}$

The Colombo Plan is a partnership concept of self-help and mutual-help in development aimed at the socio-economic progress of its member countries. ${ }^{281}$ The plan was promoted as the medium through which Western aid would be made available to the Asian countries. The main forms of assistance were grants and loans for national development projects; commodities including grain, fertilizers, and consumer goods; specialized equipment including machinery, farm equipment, transport vehicles, and laboratory equipment; services of experts and technicians; training in advanced technology to the students of the countries of the region. ${ }^{282}$ There were no strings attached to the money or support distributed through the Colombo Plan and there were no expectations of a return by the donor country. ${ }^{283}$ At a time of great political and economic uncertainty, the Colombo Plan played a crucial role in bringing together Asia and the West.

In 1950, the Colombo Plan started a process of educational engagement between Asia and Australia. The program was championed vigorously by Australia's then Foreign Minister Sir Percy Spender. ${ }^{284}$ The Australian Government funded an Australian Development Scholarship program to assist a range of developing nations. Malaysia (then Malaya) was amongst the nations that were included in the program which was instrumental in enhancing and strengthening bilateral ties, business and educational links between Malaysia and Australia. ${ }^{285}$ Richard Casey, Australia's then Minister for External Affairs, saw the interaction of the Asian students with the universities as an opportunity to

\footnotetext{
${ }^{280}$ The Hon. Alexander Downer "Launch of Australia and the Colombo Plan 1949-1957" unpaginated

${ }^{281}$ The Colombo Plan's Secretariat "The Colombo Plan" unpaginated

282 Malaysian Australian Alumni Council "Colombo Plan Anniversary Book" unpaginated

${ }^{283}$ Malaysian Australian Alumni Council “Colombo Plan Anniversary Book" unpaginated

${ }^{284}$ The Hon. Alexander Downer "Launch of Australia and the Colombo Plan 1949-1957" unpaginated

${ }^{285}$ Australian High Commission Malaysia “What are the MACC Scholarships?” unpaginated
} 
break down prejudice and misunderstandings on both sides. ${ }^{286}$ From the early 1950 s until the mid 1980s, an estimated 18,000 to 20,000 scholars were given the opportunity to study in Australian universities and approximately 4000 of them were young Malaysians. ${ }^{287}$ Malaysia was one of the plan's largest beneficiaries with Malaysian students representing $27 \%$ of the total scholarship recipients. ${ }^{288}$ These highly deserving Malaysian students made a significant impact both in Australia and in their home country.

At the time, Malaya and Singapore shared a university which was located in Singapore. ${ }^{289}$ In 1959, this branched into two autonomous divisions, one in Singapore and the other on the border between Kuala Lumpur and Petaling Jaya. ${ }^{290}$ All the universities offered a warm welcome to the Colombo Plan students throughout the 1950s until the mid 80s, though many students attended the University of New South Wales and Monash University in particular. The Colombo Plan students were under strict obligations preventing them from engaging in any form of political activity and prohibiting them from taking any form of permanent employment in Australia. ${ }^{291}$ These scholars were required to return to their own country after the completion of their studies.

Architect, Hijjas bin Kasturi, is one of the many prominent Malaysian architects who has achieved success through the program. He was awarded a prestigious Colombo Plan Scholarship in 1958 to study architecture in the University of Adelaide. He then transferred to the University of Melbourne where he graduated with a Bachelor of Architecture in $1965 .{ }^{292}$ Kasturi has contributed significantly to the development of Malaysia's architecture and has received numerous awards for his iconic building design. Kasturi formed Hijjas Kasturi Associates Sdn (HKA) in 1977, which was a time when Malaysian cities were beginning to transform from clusters of shophouses to iconic skylines. It was a vulnerable period that was characterized by strong nationalism and the search for a Malaysian architectural identity.

Despite technological advances and pressure to conform to an International Style, HKA strived to develop designs that drew from traditional ideas but still evolved towards organic form and detail to

\footnotetext{
${ }^{286}$ Oakman "Young Asians in our homes: Colombo Plan students and White Australia"p89

${ }^{287}$ Australian High Commission Malaysia "What are the MACC Scholarships?" unpaginated

${ }^{288}$ Oakman "Young Asians in our homes: Colombo Plan students and White Australia" p90

${ }^{289}$ Vaz and Tan Endeavours of excellence : over 50 years of Australian scholarships p10

The Federation of Malaysia was formally established in 1963; prior to that the country was known as Malaya

${ }^{290} \mathrm{Vaz}$ and Tan Endeavours of excellence : over 50 years of Australian scholarships p 10

${ }^{291}$ Vaz and Tan Endeavours of excellence : over 50 years of Australian scholarships $\mathrm{p} 10$

292 University of Melbourne "Award winning architect to be awarded honorary doctorate by the University of Melbourne" unpaginated
} 
exploit construction systems for new solutions. ${ }^{293}$ Kasturi's approach to architectural design in Malaysia consists of reconciling form and function within the cultural continuity. ${ }^{294}$ His knowledge and approach to space and light in architecture is influenced by his education in Australia. Kasturi has described his education as "holistic, thorough and wholesome" and has acknowledged that it has taught him about life, philosophy and humanity. ${ }^{295} \mathrm{He}$ also credits the late Australian architect, Harry Siedler, for spelling out to him three things: rationality, economy and aesthetics. Rationality taught him the importance of repeatedly asking 'why' as there needs to be a rational reason to how a building is built. Economy is about showing respect for the client's budget and to not waste resources. Aesthetics refers to the Modernist 'rules' of art, in that there is no room for gratuitous decoration and visual statements that do not comply with the rules of art. ${ }^{296}$ HKA is responsible for many of Malaysia's contemporary buildings such as the Syariah Courthouse (1986)(fig. 5.1) and Kuwait Embassy (1988)(fig. 5.2 ).
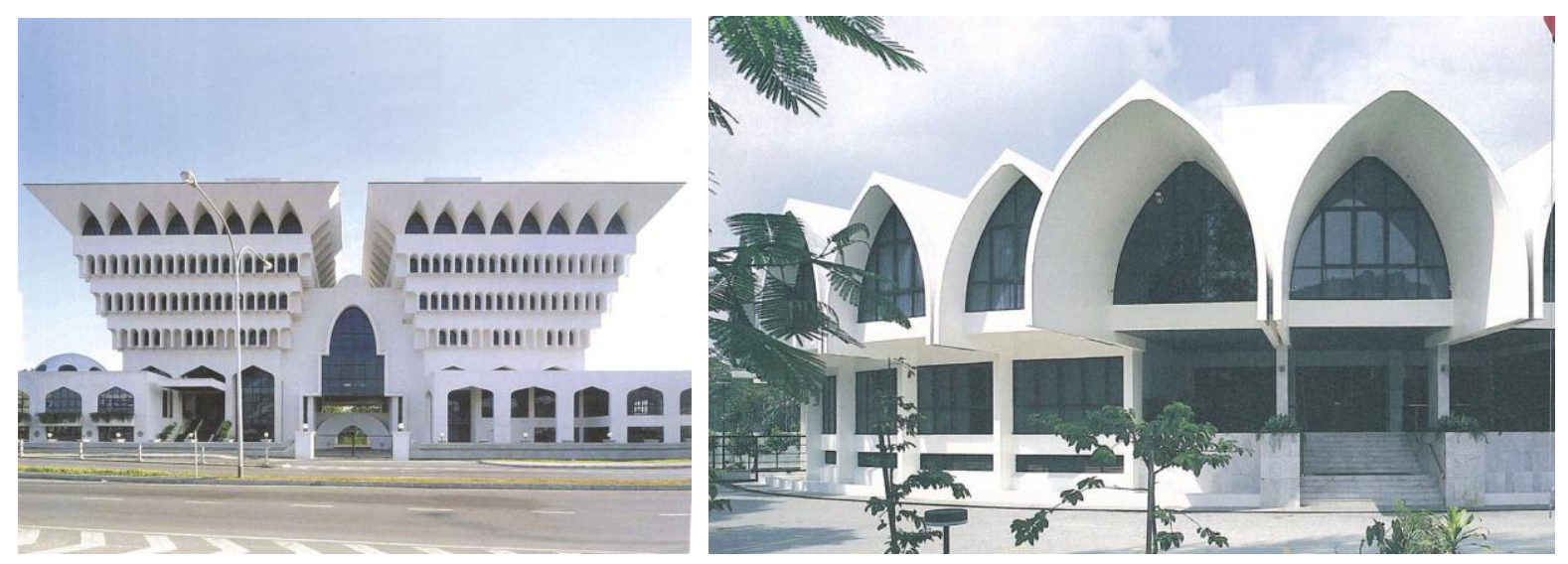

Fig. 5.1 Syariah Courthouse (1986) (left) and fig. 5.2 Kuwait Embassy (1988) (right).

Another Malaysian architect to emerge from the Colombo Plan is Francis Wong. Wong is the father of Senator Penny Wong, Australia's first Chinese-Australian woman to be elected a Labour MP. He graduated with a Bachelor of Architecture (Hons) in 1967 and has since practiced as an architect in Sabah, Malaysia. Wong attributes his successful architectural career to his experiences and professional training in Australia. He considered his contact with Western culture to have enriched his understanding of the world and its complexities. ${ }^{297}$ Since retiring in 2002, Wong has assumed the position of the Dean of Studies at the Sabah Institute of Art, teaching architecture and interior

\footnotetext{
${ }^{293}$ Hijjas Kasturi Assocates Sdn "Philosophy" unpaginated

${ }^{294}$ Hijjas Kasturi Assocates Sdn "Philosophy" unpaginated

${ }^{295}$ Vaz and Tan Endeavours of excellence : over 50 years of Australian scholarships p59

${ }^{296}$ McGillick Concrete Metal Glass: Hijas Kasturi Associates: Selected Works 1977-2007 p10

${ }^{297}$ Salkow, Howard "Australian experience builds global perspective" unpaginated
} 
design. Acknowledging the value of his education abroad, he intends to prepare the younger generation of Malaysians for globalization. ${ }^{298}$ His contribution as a qualified architect in Sabah ranges from government to public service in local councils whilst being instrumental to private sector economic and social development. ${ }^{299} \mathrm{His}$ architectural accomplishments included real estate developments, the Marco Polo Hotel in Tawau and the Borneo Resthouse Hotel in Kota Kinabalu.
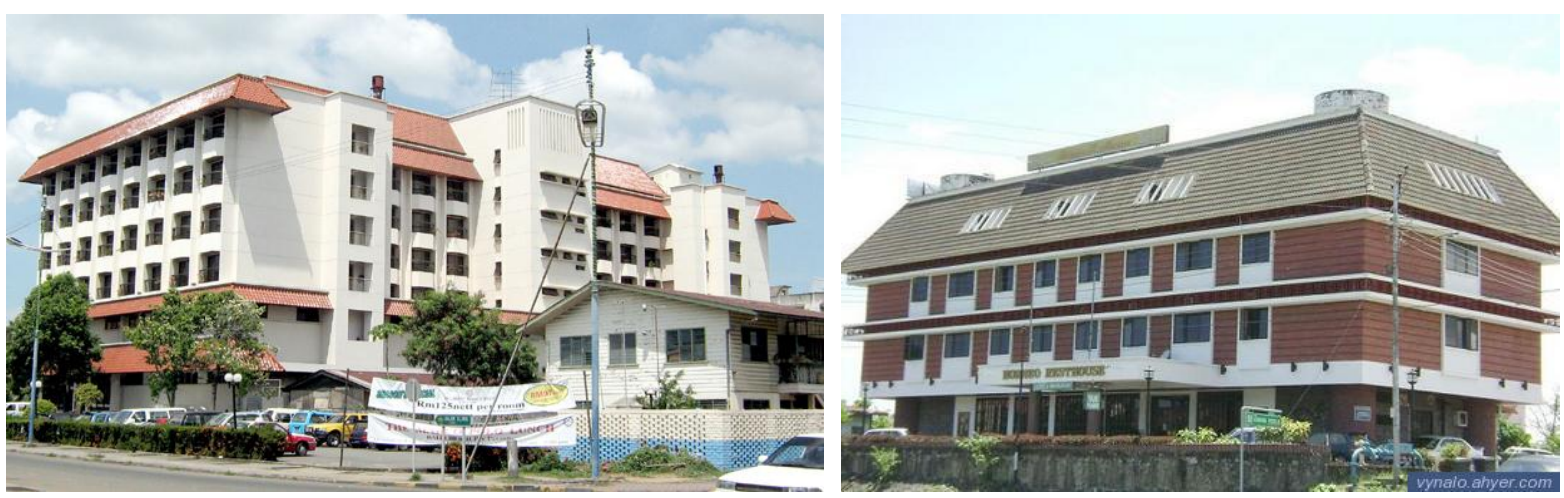

Fig. 5.3 Marco Polo Hotel, Tawau (left) and fig. 5.4 Borneo Resthouse Hotel, Kota Kinabalu (right)

The Colombo Plan scholarship program was at its peak during the 1960 s but it ended in the 1980 s. $^{300}$ The initial objectives for aiding recipient nations were changed. Malaysia was no longer a commodities-based nation but rather a country supported by a thriving industrial and manufacturing economy. ${ }^{301}$ The homecomings of the scholars were ones of mixed reactions. Most found themselves reluctant to leave Australia while also filled with pure excitement because the 1950s and 1960s was indeed an exciting time in Malaysia's history.

With Malaysia adjusting to its newly independent status and the gradual phasing out of the British Civil Service, the stage was set for the architectural pioneers of the country to apply all that they had absorbed from their time abroad towards building their new nation. ${ }^{302}$ Education taught with the values of external cultures can have a significant influence on attitudes towards indigenous culture as philosophies of architecture which were largely oriented towards a foreign perspective. ${ }^{303}$

\footnotetext{
${ }^{298}$ Salkow, Howard "Australian experience builds global perspective" unpaginated

${ }^{299}$ Sauer The Colombo Plan for cooperative economic development in South and South East Asia 1951 - 2001 p58

${ }^{300}$ The Malaysia Australia Colombo Plan Commemoration (MACC) Scholarships were launched in October 2001 and builds on the spirit of the Colombo Plan in enabling Malaysian students to study in Australia.

${ }^{301}$ Vaz and Tan Endeavours of excellence : over 50 years of Australian scholarships p 11

${ }^{302}$ Vaz and Tan Endeavours of excellence : over 50 years of Australian scholarships p36

${ }^{303}$ Encyclopedia of Vernacular Architecture of the World p122
} 


\section{International Modernism}

The spread of modern architecture in the country came about at the end of the 1950s when the younger generations returned from their education abroad, influenced and inspired by the principles of architect such as Le Corbusier, Alvar Aalto and Mies van der Rohe. There seemed to be a uniform acknowledgement that modern architecture, with a pure form, emerged through the genius of a mind uncorrupted by lessons of history, and should be followed as such. ${ }^{304}$ This style was known as the International Modernism or the International Style. Another source responsible for the dispersion of the style was from the media. Forms of media, such as books, magazines and television, have played an influential role by introducing and emphasising the idea of a 'new architecture' to the society. ${ }^{305}$

The International Style is considered to be the antithesis of vernacular architecture. The buildings of this style seemed to disregard the environmental context, are disinterested in climatic conditions (because of their hermetically sealed buildings and air-conditioning) and have no apparent cultural references. $^{306}$

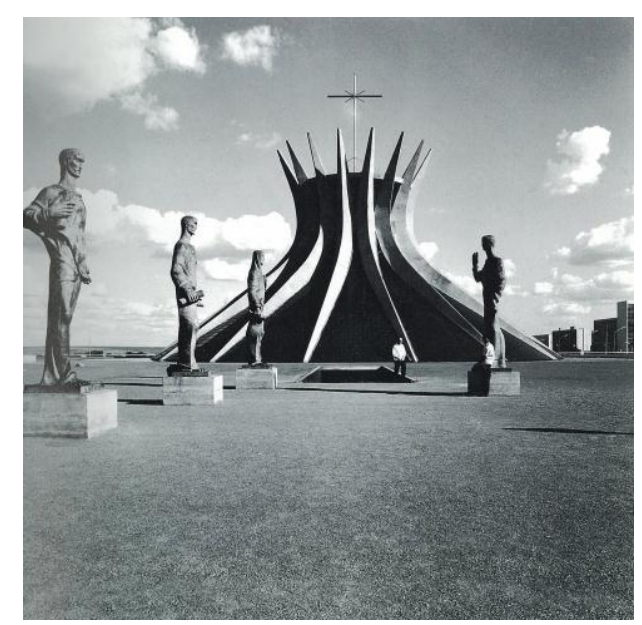

Fig. 5.5 Metropolitan Cathedral (1959) in Brasilia

Oscar Niemeyer and his approach to contemporary Brazilian architecture became of great interest to architects in Malaysia because Brazil has a similar equatorial and tropical climate. ${ }^{307}$ His architectural work reflects a compromise between the dialectics of modernism and the Brazilian milieu. Niemeyer advanced beyond the rigid, rectilinear geometry of the International Style to generate a pioneering, free-form modernism that was uniquely Brazilian. ${ }^{308}$ Instead of merely following and applying Modernist ideology, Niemeyer modified European concepts to adapt to the Brazilian context.

\footnotetext{
${ }^{304}$ Ismail Houses in Malaysia. Fusion of the East and the West p83

${ }^{305}$ Ismail Houses in Malaysia. Fusion of the East and the West p48

${ }^{306}$ Lim and Tan The New Asian Architecture. Vernacular Traditions and Contemporary Style p13

${ }^{307}$ Yeang The Architecture of Malaysia p227

${ }^{308}$ Underwood Oscar Niemeyer and the Architecture of Brazil p15
} 
Niemeyer was known to create freely curving concrete edifices that steered away from lines and rigid geometric shapes that predominate in Modernism. One of Niemeyer's masterpieces that demonstrates this fluid, sculptural approach includes the Metropolitan Cathedral (1959) in Brasilia (fig. 5.5). The building consists of sixteen curved ribs that repeat in a rotational symmetry.

To adapt to the climatic requirements of Brazil, Niemeyer's contemporary works often featured Corbusian brise-soleil (slatted sun-screens on the external walls). These sun shading devices started to appear in Malaysian architectural designs, indicating the return of a climatologically-conscious architecture.

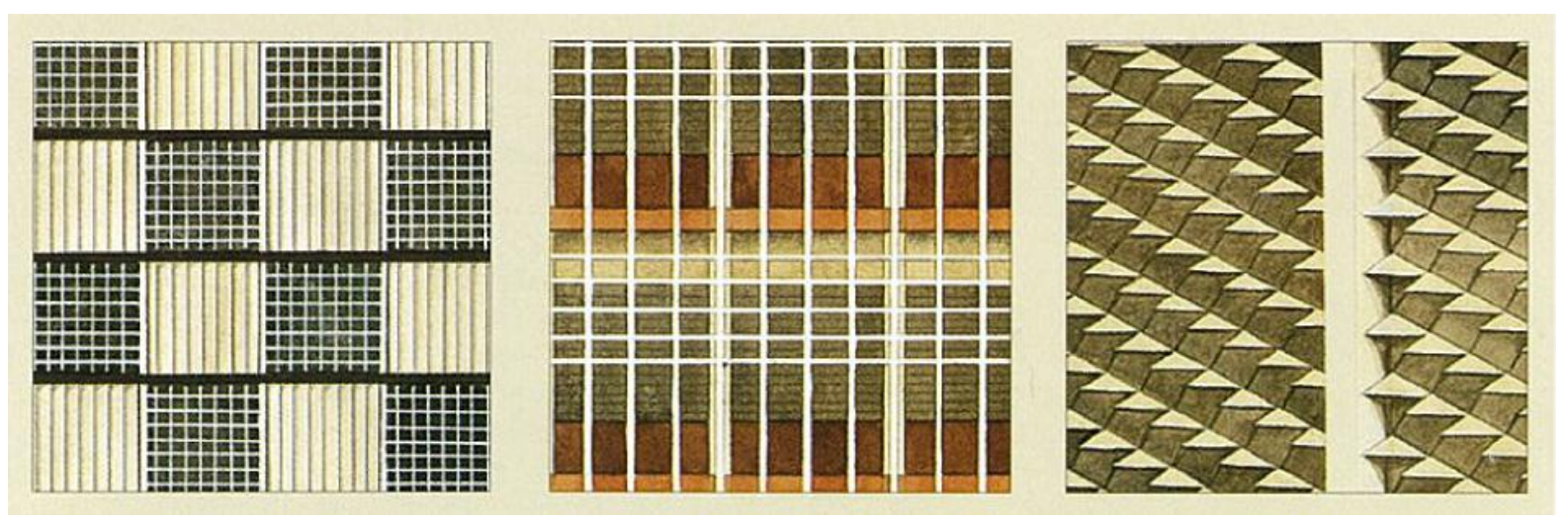

Fig. 5.6 - fig. 5.8 Concrete fins and screens (left), horizontal and vertical louvers (centre), and metal sunscreen cladding (right)

Figures 5.6-5.8 illustrate the sunshading devices commonly used in the design of buildings in Malaysia during the early 1960s. The use of concrete fins and screens can be seen on most government buildings designed by the PWD. ${ }^{309}$ The horizontal and vertical louvres are reminiscent of colonial tropical designs and hint at regional characteristics in tropical design. ${ }^{310}$ The unusual external metal sunscreen cladding was employed by buildings such as the American International Assurance (AIA) building in Kuala Lumpur. ${ }^{311}$

\section{National Identity}

A prosperous economy and the growing confidence of the nation led to local adaptations of the International Style. One response was to accommodate to the climate, which was evident in the use of sun-shading devices such as metal grilles or concrete blades and screens seen in the Parliament Building and the Kuala Lumpur General Hospital.

\footnotetext{
${ }^{309}$ Chen 'Architecture' The Encyclopaedia of Malaysia p106

${ }^{310}$ Chen 'Architecture' The Encyclopaedia of Malaysia p106

${ }^{311}$ Chen 'Architecture' The Encyclopaedia of Malaysia p106
} 
Employing local building materials was often a strategy used to modify the austerity of Functionalism and to portray a clearer sense of national identity. ${ }^{312}$ However, as timber was a flammable material, the vernacular was restricted to image-making, with concrete as the universal building material. Four contemporary Malaysian buildings will be examined, which were built Post Independence (the Parliament House (1963) in Kuala Lumpur, Muzium Negara (National Museum) (1963) in Kuala Lumpur, Bank Negara (National Bank) (1983) in Kedah and Lembaga Urusan Tabung Haji (LUTH) (1984) in Kuala Lumpur), as examples which demonstrate a shift towards vernacular tendencies, expressing traditional identity through their silhouette and façade forms, as well as taking into account climatic considerations.

The Parliament House (1963), Kuala Lumpur

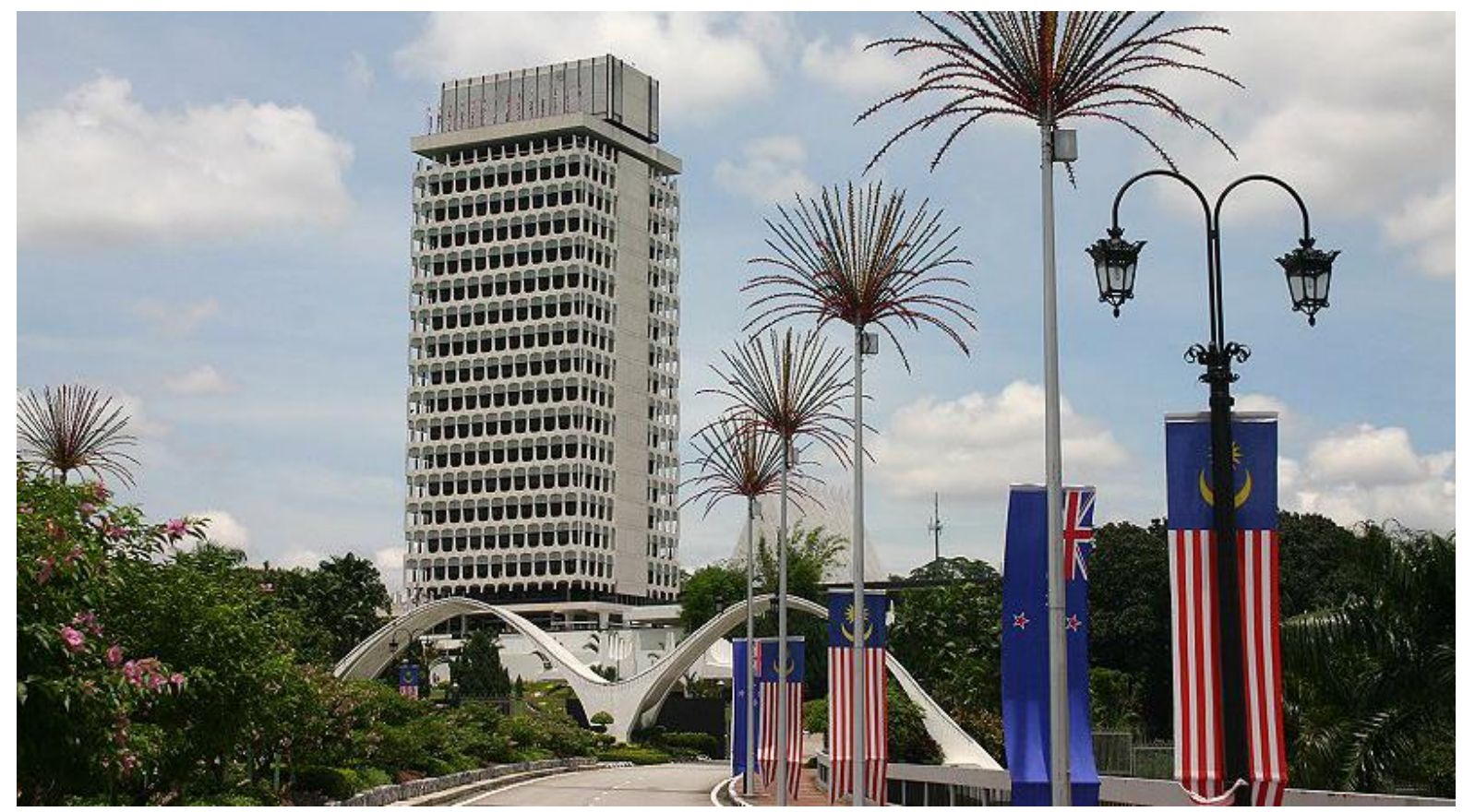

Fig. 5.9 The Parliament House (1963), Kuala Lumpur

The Parliament House was a symbol of Malaysia's newly acquired status as an independent nation. The building is located in the capital, Kuala Lumpur, and was completed in 1963. This new national symbol, designed by British architect, Ivor Shipley of the PWD, faced many design constraints as it could not make any references to colonialism, be it Neo-Classical or pre-war ideas of 'Modernism'. ${ }^{313}$ The eighteen storey building expressed the modern architectural language of the International Style, consisting of the ubiquitous office tower block and a large three storey podium housing the Senate

\footnotetext{
${ }^{312}$ McGillick Concrete Metal Glass: Hijas Kasturi Associates: Selected Works 1977-2007 p9

${ }^{313}$ King Kuala Lumpur and Putrajaya: negotiating urban space in Malaysia p100
} 
and the House of Representatives. ${ }^{314}$ The podium is crowned with eleven triangular concrete pinnacles. This made references to the form of traditional roofs, alluding to the high pitched angles of the Bugis or Melaka gable roofs (fig. 5.14)

The façade and forms of the Parliament House emulate the International Style characteristics of grid-like patterns, repetition and the expulsion of applied ornamentation. However, the building addresses the issues of climatic response by the use of decorative 'armadillo shaped' precast cladding which functions as a sun shading device. As the Parliament building was one of the first Post Independence experiments, the transition between the British colonial architectural styles to a more regionally expressive identity is evident in the contrast between the tower block and the podium roof.
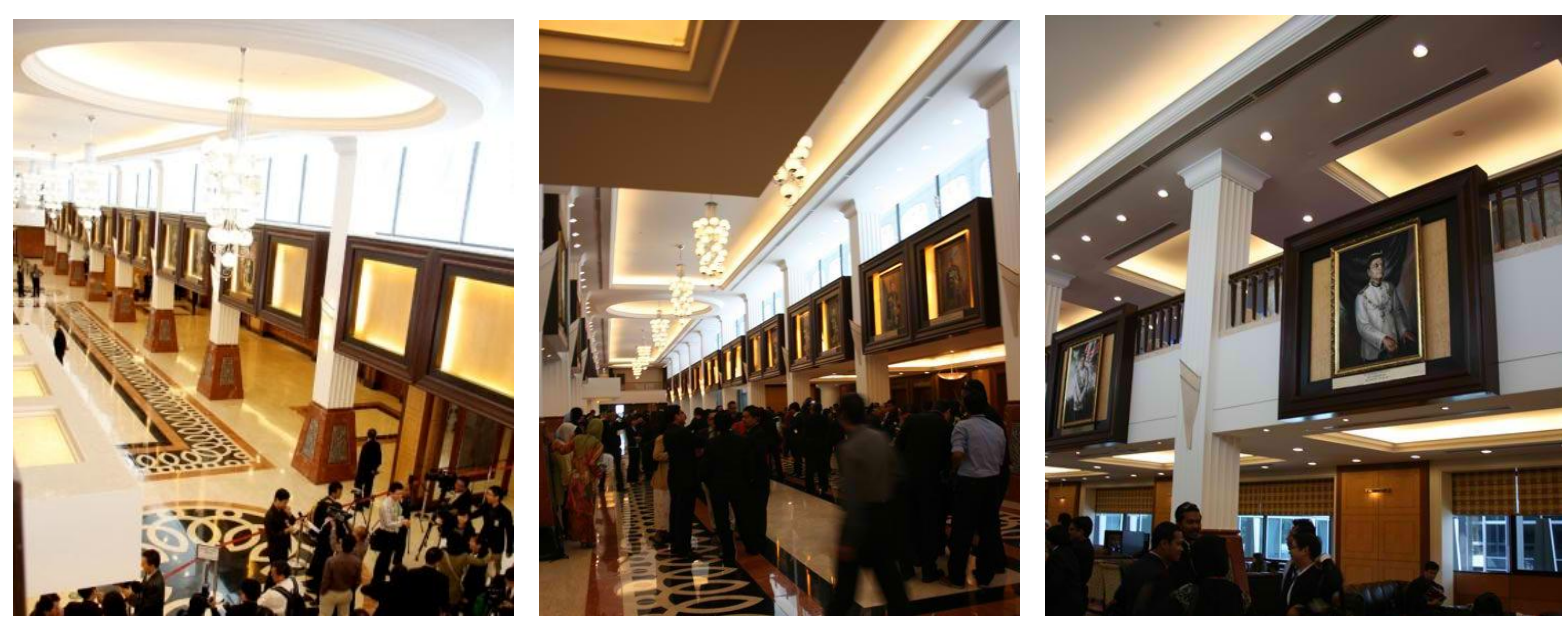

Fig. 5.10-5.12 The lobby of the Parliament House exhibited classical pillars and ornate mouldings on the walls and ceilings which contrasted the unornamented walls of the exterior.

Professor Rasdi has written of his appreciation of the echoes of socialism and non feudalistic statements conveyed by the pristine white and grey exterior composition of the building. However, in 2005, the building underwent renovations and Rasdi has observed that the new interiors (fig. 5.10-5.12) had reverted to the pre-colonial days of feudalism, revealing fat classical pillars and ornate mouldings that adorn the simple walls and ceilings. ${ }^{315}$ This was in contrast to its shell which speaks of the revolution against the ornamentalised aristocratic architecture of the Ecole de Beaux Arts. ${ }^{316}$

\footnotetext{
${ }^{314}$ Chen 'Architecture' The Encyclopaedia of Malaysia p109

${ }^{315}$ Rasdi "Masterminding the Architectural Heritage in Malaysia" p28

${ }^{316}$ Rasdi "Masterminding the Architectural Heritage in Malaysia" p28
} 

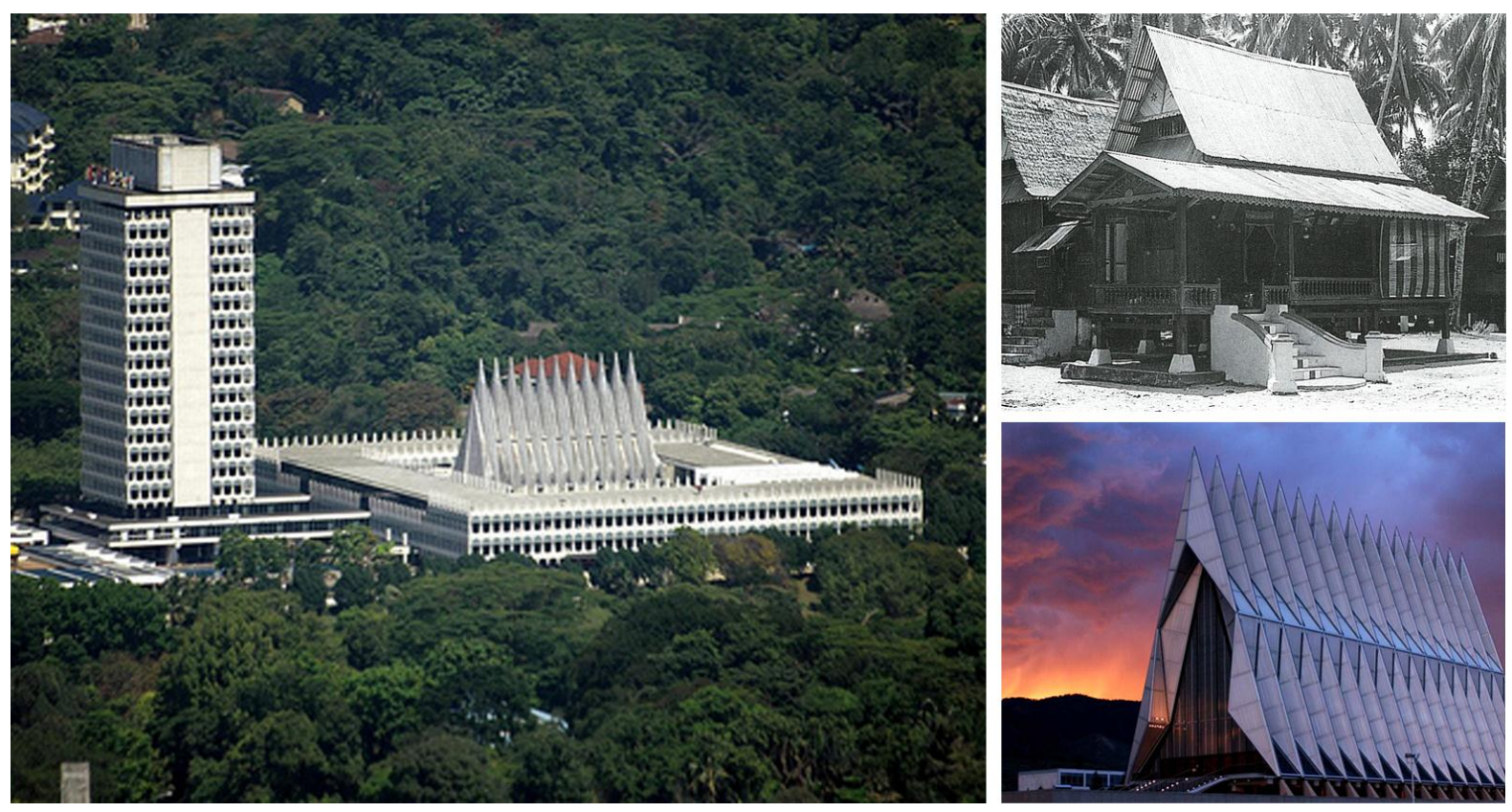

Fig. 5.13-5.15 The triangular concrete pinnacles of the Parliament House (left), a Malay house in Melaka (top right) and the United States Air Force Academy chapel in Colorado(bottom right)

The design of Parliament house was perhaps one of the country's earliest examples that made references to the vernacular by employing abstracted forms that are evocative of traditional imagery. These forms were possibly inspired by foreign architecture as the forms used were comparable to other buildings abroad. For example, the eleven triangular concrete pinnacles of the Parliament house possess a resemblance to the seventeen glass and aluminium spires of the United States Air Force Academy chapel in Colorado (fig. 5.15). The chapel was designed by Skidmore, Owings and Merill and was first conceived in the mid-1950s and also completed in $1963 .{ }^{317}$

The Post Independence period was a time when the architecture of statehood took the form of expressive monuments which were meant to symbolize Malaysia's new status as an independent nation, technological prowess and economic strength. The design of Parliament House did not display an eagerness to immediately shake off colonial associations but instead embraces it as its past. The eclectic combination of colonial and regional styles is a transitional part of the dynamic process of development to adapt to the change in its social context.

${ }^{317}$ Stone "Parliament House, Kuala Lumpur" p11 


\section{Muzium Negara (National Museum)(1963), Kuala Lumpur}

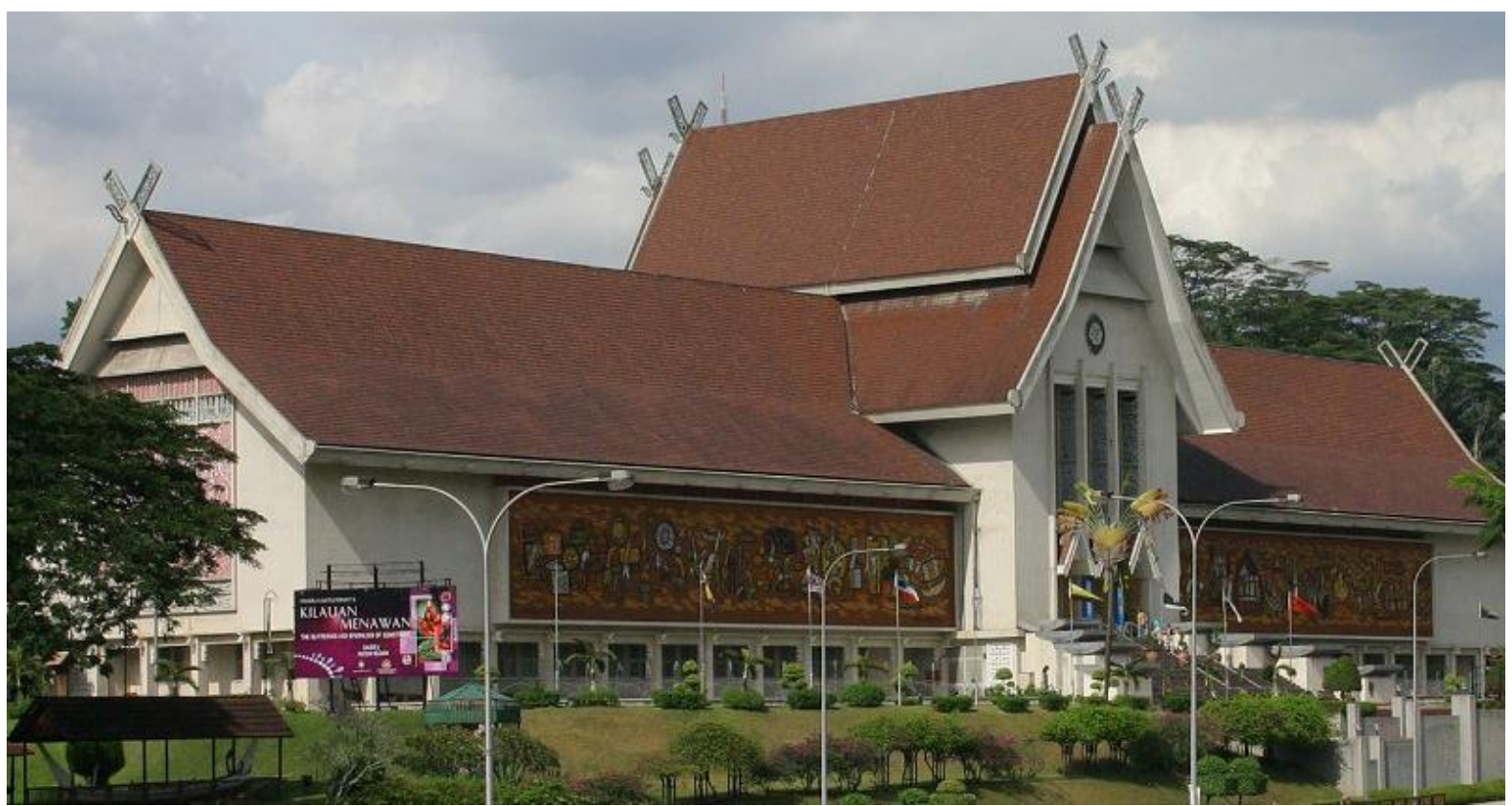

Fig. 5.16 The National Museum (1963), Kuala Lumpur

The National Museum in Kuala Lumpur is another example that demonstrates the synthesis of colonial and local styles. Constructed at the same time as the Parliament House, the museum was also meant to be a showpiece for the newly independent country, becoming a landmark that signified an important time in the country's history. ${ }^{318}$ The design of the National Museum building was based on the aesthetic elements of traditional Malay palace architecture. ${ }^{319}$ The government appointed Singaporean architect, Ho Kok Hoe, to design the National Museum. Ho visited the northern Malay states to study indigenous architecture which he deemed suitable to serve as a model for the museum. ${ }^{320}$

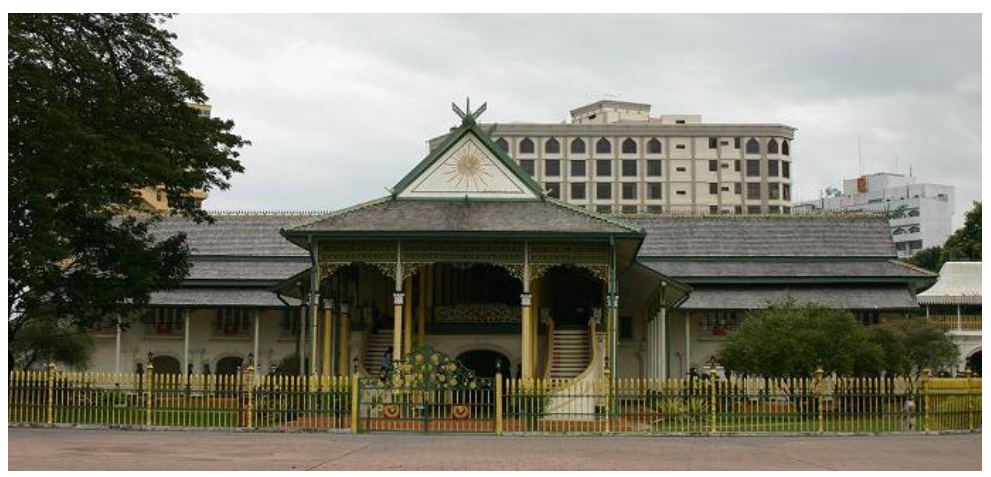

Fig. 5.17 Balai Besar (Great Council Hall) located in Alor Setar, Kedah

The chosen design was inspired by the historic Balai Besar (Great Council Hall) (fig. 5.17) which is located in Alor Setar, Kedah. The

\footnotetext{
${ }^{318}$ Yeang The Architecture of Malaysia p210

${ }^{319}$ Muzium Negara "History" Muzium Negara unpaginated

${ }^{320}$ Yeang The Architecture of Malaysia p210
} 
museum incorporated the traditional Malay architecture tripartite division of kolong (underside of a Malay house raised on stilts), main body and pitched gable roof. ${ }^{321}$ The double-pitched roofs on the two side wings are adapted from Melaka, Bugis and Terengganu roof forms. ${ }^{322}$ The kolong is rather conspicuous in the design of the building as the recessed walls of the ground floor allow the formation of a colonnade. The building is supported by 26 concrete columns that have been modified to retain traditional Malay palace features. The combination of 13 columns in the east wing and the other 13 in the west wing represents the 13 states that form Malaysia. ${ }^{323}$ The front façade of the building is decorated with two murals depicting Malaysian historical events and culture in the style of batik (traditional hand-dyed fabric) painting. Murals commonly feature on walls on institutional buildings, a practice adopted in the immediate post-Independent Malaysia to promote statehood. ${ }^{324}$ Climatic concerns were also addressed through the deeply shaded glass walls of the ground floor which served to protect the administrative offices from the harsh sun. ${ }^{325}$

The design of the National Museum is a literal adaptation of the recognisable elements of the traditional Malay house which are transposed from a small domestic scale to a monumental public structure. This approach has been described as "balloonism". ${ }^{326}$
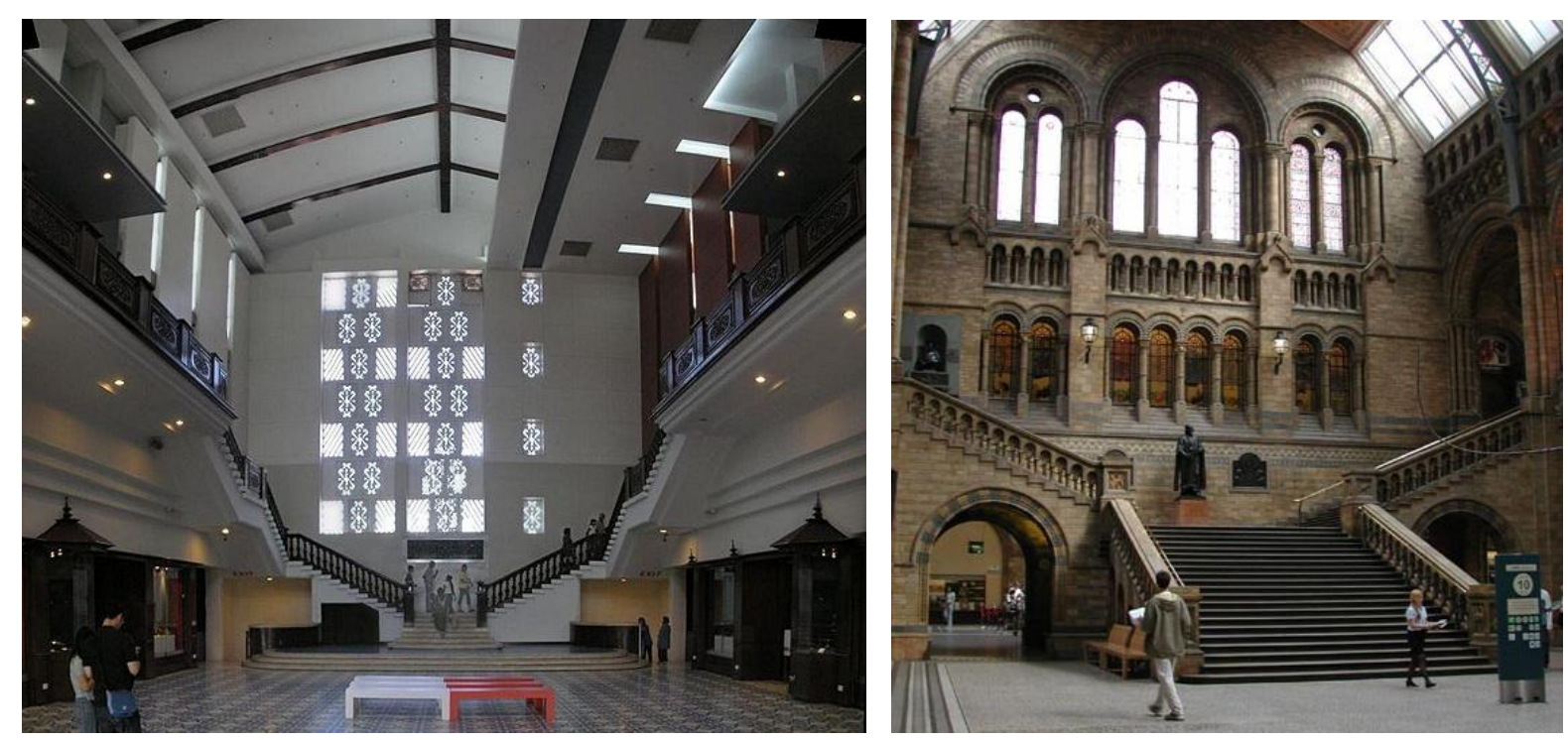

Fig. 5.18 National Museum, Kuala Lumpur (1963) (left) and fig. 5.19 Natural History Museum, London (1881) (right)

\footnotetext{
${ }^{321}$ Chen 'Architecture' The Encyclopaedia of Malaysia p107

${ }^{322}$ Chen 'Architecture' The Encyclopaedia of Malaysia p107

${ }^{323}$ Muzium Negara "History" Muzium Negara unpaginated

${ }^{324}$ Chen 'Architecture' The Encyclopaedia of Malaysia p109

${ }^{325}$ Chen 'Architecture' The Encyclopaedia of Malaysia p107

${ }^{326}$ King Kuala Lumpur and Putrajaya: negotiating urban space in Malaysia p105
} 
Similar to the Parliament House, the museum was constructed during the transition between colonialism and adaptation to a new independent status. It has been described as the first monumental work in Malaysia that clearly departed from the Modernist vocabulary in favour of Neo-Traditionalism ${ }^{327}$ However, the design of the building still holds traces of foreign influences as it can be argued that the approach was inspired by the colonial synthesis of the monumentality of European Classicism and Malay vernacular architecture. This is evident in the symmetrical plan of the museum, a characteristic of Classical architecture. There is also a suggestion of ornamentation on the column capitals. ${ }^{328}$

\section{The Bank Negara (National Bank), Kedah (1983)}
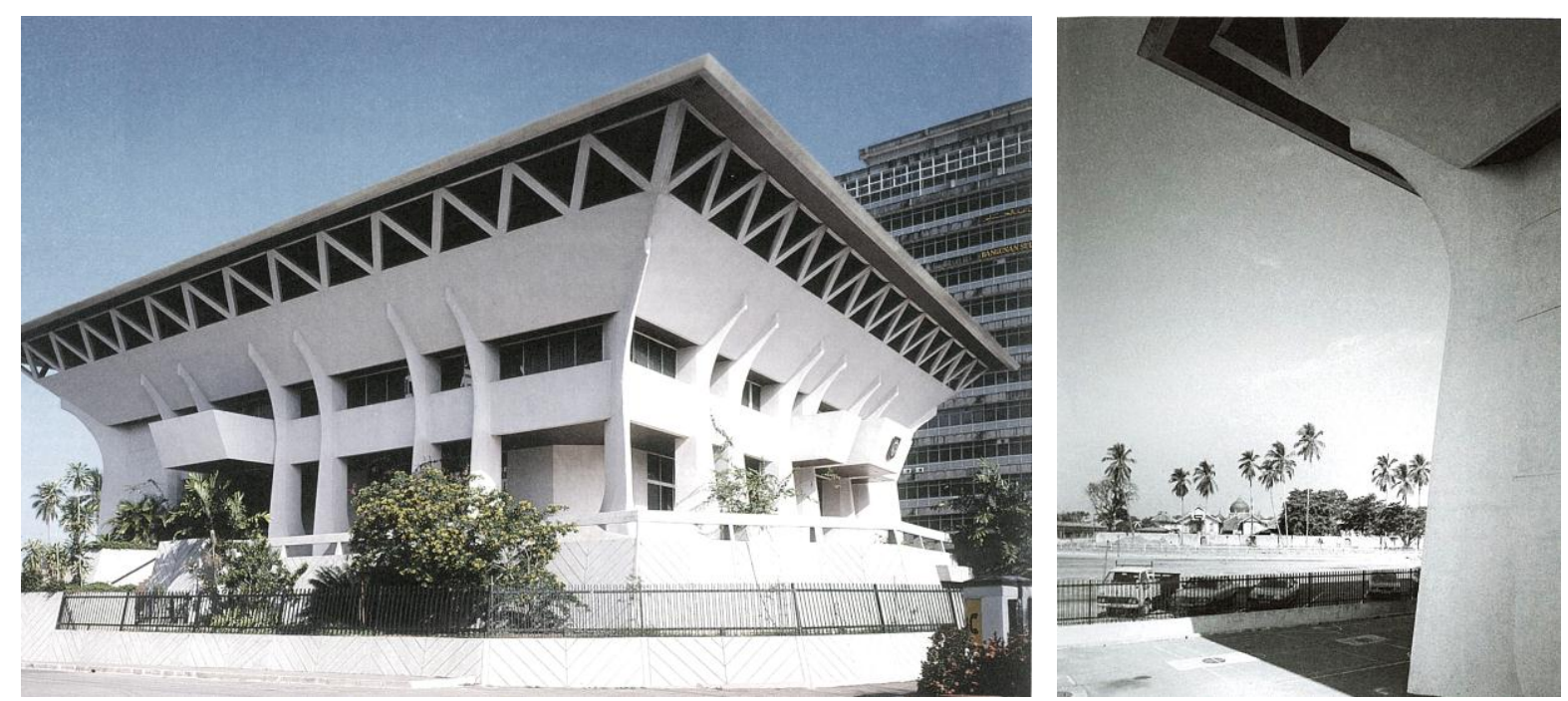

Fig. 5.20 The Bank Negara (National Bank) (1983) (left), Kedah and fig. 5.21 the detail of the external pillar (right)

In the humid tropical climate of Malaysia, concrete quickly becomes stained by unsightly mould, resulting in the need for diligent maintenance. The design of the Bank Negara in Kedah by HKA, demonstrated a solution relating to sculptural form and the protection of façade from humidity and the weather. To protect the walls, the upper floors of the building are cantilevered, freeing more of the ground level from the building floor plate. ${ }^{329}$

The sculptural form of the curved external pillars and the zigzag trusses were inspired by the coconut palms that used to surround the site. However, not only were there responses to the building's

\footnotetext{
${ }^{327}$ Chen 'Architecture' The Encyclopaedia of Malaysia p107

${ }^{328}$ Chen 'Architecture' The Encyclopaedia of Malaysia p107

${ }^{329}$ McGillick Concrete Metal Glass: Hijas Kasturi Associates: Selected Works 1977-2007 p43
} 
environmental context, the forms signify a break from the rigid and rectangular geometry of the International style.

\section{The Lembaga Urusan Tabung Haji Building (LUTH) (1984), Kuala Lumpur}

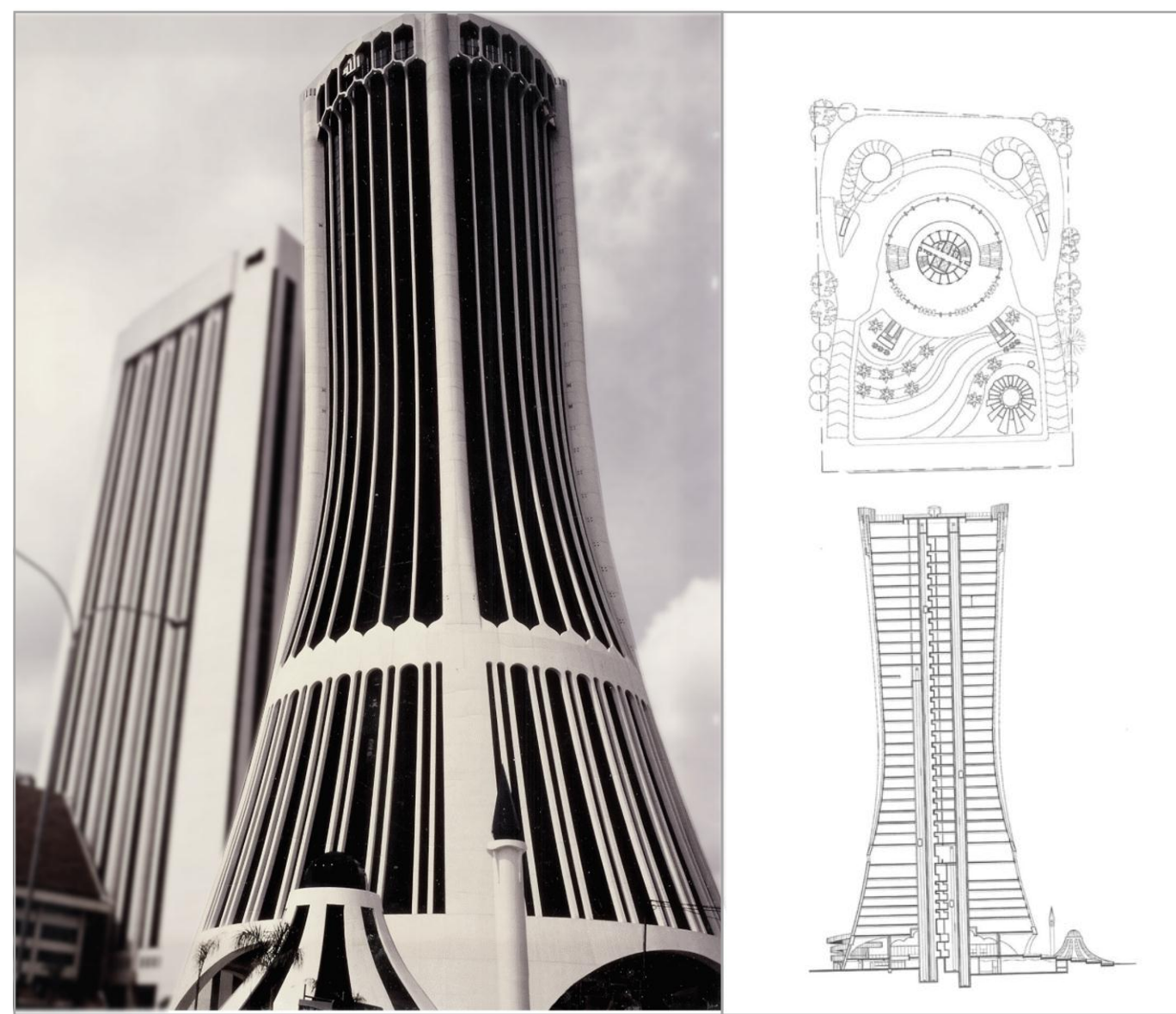

Fig. 5.22 Lembaga Tabung Haji (Pilgrim's Fund) (1984) (left) in Kuala Lumpur and fig. 5.23 plan and section of the building (right)

The Lembaga Urusan Tabung Haji Building (LUTH) is one of Kuala Lumpur's prominent landmarks and was designed by HKA in 1986. The tower, located along Jalan Tun Razak, represents a sculptural model that continues the traditions of Islamic architectural forms in a modern building. ${ }^{330}$ The building is a government-run entity which manages savings for Malaysian Muslims wanting to make the pilgrimage to Mecca. ${ }^{331}$ The institutional occupier of the building demanded that recognizable Islamic symbolism be incorporated in the design. ${ }^{332}$

\footnotetext{
${ }^{330}$ Chen 'Architecture' The Encyclopaedia of Malaysia p116

${ }^{331}$ McGillick Concrete Metal Glass: Hijas Kasturi Associates: Selected Works 1977-2007 p35

${ }^{332}$ Yeang The Architecture of Malaysia p313
} 

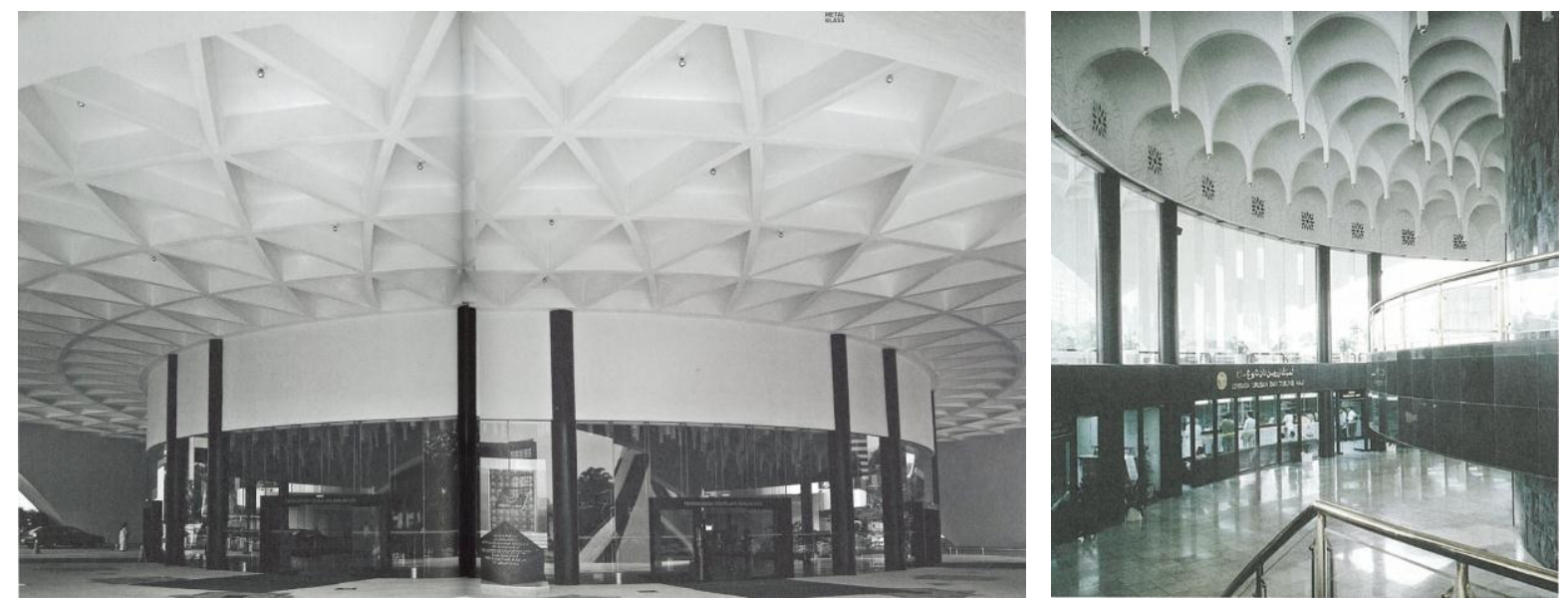

Fig. 5.24 the ribbed roof detail at the main entrance (left) and fig. 5.25 the moulded ceiling above the entrance (right)

The cultural references embedded in the design were revealed in an oblique and metaphorical approach. The tapered and flared form derive from the use of circular and arch geometrical components, white vertical mullions and the five massive, bracing columns symbolize the Five Pillars of Islam. ${ }^{333}$ The arrangement of pillars and arches provides a sturdy base for the tower as well as acting as a climatic transition between the exterior and interior. The circular plan of the tower was meant to provide a simple and straightforward orientation for the benefit of the rural members who might be unfamiliar with high rise structures at the time. ${ }^{334}$ The more apparent symbols include the Islamic inscriptions on the tower façade and a minaret for the surau (prayer room)

\section{Chapter Conclusion}

Chin acknowledges that the advantage of overseas trained architects is their open minded approach in their appraisal of local design elements. ${ }^{335}$ For example, Kasturi's approach to capturing tradition in contemporary Malaysian architecture goes beyond the sentimental revival of vernacular forms. Visual metaphors are inherent in the building's structure and fabric allowing traditional references to be made without compromising the building's commitment to modernity. ${ }^{336}$

Notions of identity have always been intricately related to traditions. ${ }^{337}$ AlSayyad states that an important lesson in the study of architecture of post-colonial societies involves the constant evolution of national identity. If we accept hybridity as an inherent quality of national identity, then

\footnotetext{
${ }^{333}$ NZ Islam Awareness "What are the Five Pillars of Islam?" unpaginated

The Five Pillars of Islam are the framework of the Muslim life: testimony of faith, prayer, giving zakat (support of the needy), fasting during the month of Ramadan, and the pilgrimage to Mecca, once in a lifetime for those who are able.

${ }^{334}$ McGillick Concrete Metal Glass: Hijas Kasturi Associates: Selected Works 1977-2007 p48

${ }^{335}$ Chin "Towards a National Identity in Architecture" p21

${ }^{336}$ McGillick Concrete Metal Glass: Hijas Kasturi Associates: Selected Works 1977-2007 p7

${ }^{337} \mathrm{Lim}$ and Tan The New Asian Architecture. Vernacular Traditions and Contemporary Style p13
} 
the ensuing architecture can only reflect the specific stage of transition that a particular society is going through. ${ }^{338}$

While the characteristics of the European models of Modernism don't conform to the definitions of vernacular architecture, the coalescence of traditional references and foreign ideas generate a different product. Hybridisation becomes an important part of the dynamic development of architecture, as the vernacular is transitional and continually evolving through transformations and innovations and exists in the recognition of finding a balance between regional and international identities. It can be argued that these Post-Independent buildings are new manifestations of the vernacular as it changes and adapts when necessary to variable cultural environments and the nature of social growth. The vernacular threshold is crossed when a localized response to broad cultural systems, historical events and environmental requirements are acknowledged.

${ }^{338}$ AlSayyad Forms of Dominance p24 


\section{Conclusion}

The term 'vernacular architecture' has historically carried connotations of 'backwardness' in contrast to progress and development. It is stereotyped as referring to simplistic and unrefined structures. In reality, the vernacular comprises sophisticated and complex cultural, social, intellectual and functional identities.

The argument central to this thesis establishes the vernacular as a dynamic process involving building traditions that continuously evolve while remaining regionally distinctive and relevant. Hybridisation becomes an important constituent during the process of adapting to the changing environment, resulting in the creation of a hybrid architecture.

Chapters one and two revealed the complex nature of the Malay house and the longhouses of Sarawak. They established that the concepts of sharing and cooperation are fundamental within these communities. Within communities that favour such communal intimacy, it is cultural conventions and cues that control the information linking social organisation with the built environment. Such conventions demarcate intangible and invisible boundaries that distinguish public and private domains, gender territories and the use of a space throughout the day. Expressions of hierarchy and status seem to be more conventional and orthodox, expressed by means of size and ornamentation, the adoption of material possessions and furniture, and the use of modern and imported materials.

History has shown that architecture has never remained stagnant and attributed to a single source of origin. It is important to acknowledge the manner in which the architectural forms of cultures and their precedents are always linked to a series of a hybrid crosses between indigenous and imported cultures. They have been diffused, hybridised and synergised, each becoming a potential model capable of generating more transformations. ${ }^{339}$ These transformations are evident in Malaysian vernacular architecture, as seen in the traditional Malay house and the longhouses of Sarawak, which share recurrent features similar to other dwellings found throughout Southeast Asia. This emphasizes the importance of not recognizing the vernacular as "pure" cultures but as a hybrid product of interpretation, negotiation and adaptation throughout generations.

The third chapter chronologically explored the significant events that transpired throughout the history of Malaysia. It was imperative to consider the vernacular throughout time and cross culturally in order to trace regularities and determine whether generalisations which are made

\footnotetext{
${ }^{339}$ Lim and Tan The New Asian Architecture. Vernacular Traditions and Contemporary Style p55
} 
might be valid. The investigation of immigrant and colonial architecture was crucial in the understanding of how the vernacular is perceived during intercultural exchanges. I examined specific buildings as well as building types that had left a profound impact in the country at its time. From the examinations, it was apparent that the immigrant and colonial rulers introduced new buildings types that could be categorized as either transplanted forms or embraced as a vernacular form. Structures such as the Portuguese A. Famosa fort, the Dutch Stadhuys and Christ Church were reproductions that mimicked the architecture of their homelands without engaging with its new surroundings. Perhaps this was a similar case to the Dutch rule in Indonesia where colonial artifices were forced onto the indigenous to exercise immediate control over local communities. ${ }^{340}$ As there was insufficient time to consider and refine the architectural style, basic building techniques and methods were taken directly from the European vocabulary out of practical necessity. ${ }^{341}$ The colonial buildings constructed by the British, however, gradually transformed and evolved to incorporate a synthesis of selective vernacular principles. These modifications and alterations were inevitable as well as necessary in order for the buildings to adapt and function effectively in their new geographic and cultural environment.

The colonial period paved the way for urban infrastructure such as civic, administration and recreational buildings that did not appear to have any conceivable local parallels in the country. However, cross-sectional comparisons drawn between the architecture of the indigenous and of foreign origin demonstrates that no building can be described as entirely new and that the vernacular assists in making new building types seem comprehendible. It is the epistemological aspects of the vernacular that provide hints that allow the local population to identify themselves in relation to a place and the history of a place.

The fourth chapter focused on the colonial architecture of the British as they made the most impact on Malaysian architecture during their colonial rule. With the imposition of foreign cultures came the opportunities for alternate lifestyles. The physical and psychological need for privacy increases as a society moves from 'primitive' to 'modern' thus leading to the proliferation of detached houses such as the bungalow, villa and mansion, which signified the shift away from communal dwellings to more private and isolated residences. The chapter looked at the development of detached houses such as the bungalow, villas and mansions, and the responses of these building types to regional dynamics. The changes evident in the building's form, plan, structure, or use, reflect the choices

\footnotetext{
${ }^{340}$ Widodo "Modern Indonesian Architecture" p19

341 Widodo "Modern Indonesian Architecture" p19
} 
people have made in adapting elements in their built environment. This response to new regional realities results in the formation of the new vernacular.

The last chapter led with the study of the Colombo plan as exposure to foreign architecture contributed to the spread of modernism in the country. Education overseas had significant influence on attitudes towards indigenous culture, especially as the rapid process of urban growth and development did not allow architects the time to formulate an appropriate theory before proceeding. The Modern Movement in architecture influenced practicing architects to observe the tenets of the 'International Style' on the design of buildings. These trends tend to obscure the importance of designing in response to the environment and to fulfil the spiritual and physical requirements of a country's inhabitants, effectively becoming the antithesis of vernacular architecture.

During the 1950s and 1960s, following independence, the issue of achieving a Malaysian architectural identity reached a critical point, prompting a critical re-evaluation of the fundamental principles of the International Style among concerned local architects. As the notions of identity have always been intricately synonymous with traditions, Malaysian architecture began to produce buildings that demonstrate the blending of traditional forms with contemporary ideas. This synthesis of the vernacular with modernism is a way of thinking about architecture as cultural regenerationnot a style; a search for cultural continuity in the aftermath of the colonial experience. ${ }^{342}$

\section{The significance of findings}

Theories of the vernacular and the evolution of modern architecture are closely intertwined, transforming the fundamental notions of style, building and dwelling. The study of vernacular architecture provides potentially valuable insights. Lessons of the past provide valuable insights on how the present functions. In realizing the need for vernacular continuity, tradition is manifested as superimposed layers of inventions as opposed to being constituted as an immutably fixed set of devices and images.

It is not possible to retain every aspect of a past vernacular, as it would be pointless to build configurations for cultures and lifestyles that are now irrelevant. The realities of the present need to be contended with. The underlying challenge exists in seeking ways to effectively localise imported technologies, materials, ideas and built forms to best fulfil the building, and its programme, and to be beneficial to the local community. The aim is innovation not duplication.

${ }^{342}$ Powell The Asian House: Contemporary Houses of South East Asia p10 


\section{References}

Abel, Chris Architecture and Identity Responses to Cultural and Technological Change (Oxford: Architectural Press, 1999)

Abel, Chris "Built Sources of Malaysian Identity" Majallah Akitek (March 1985) v.85, n.3, pp. 32-40.

Ahmad, A. Ghafar "Syed Alatas Mansion" School of Housing, Building \& Planning (January 1996) http://www.hbp.usm.my/townplg/heritage/alatas.htm

Ahmad, A. Ghafar "Southern Chinese Architecture" School of Housing, Building \& Planning (April 2010) http://www.hbp.usm.my/conservation/chinese_architecture.htm

Ahmad, A. Ghafar "The Architectural Styles of The British Colonial Buildings in Malaysia" School of Housing, Building \& Planning (April 2010)

http://www.hbp.usm.my/conservation/British/britishcolonial1.htm

Ahmad, A. Ghafar "The Architectural Style of The Peranakan Cina" School of Housing, Building \& Planning (April 2010) http://www.hbp.usm.my/conservation/SeminarPaper/peranakan\%20cina.html

Ahmad Sarji bin Abdul Hamid "Message from the President" Badan Warisan Malaysia (June 2006) http://www.badanwarisan.org.my

Airs, Malcolm The Tudor and Jacobean Country House. A Building History (United Kingdon: Alan Sutton Publishing Limited, 1995)

Alexander, Jennifer "The Lahan Longhouse" Inside Austronesian Houses ed. Fox, James J. (Australia: Department of Anthropology, 1993) pp. 31-43

Arch Net "Malacca” Arch Net (April 2010) http://www.archnet.org

Ascott House "Cricket at Ascott" Ascott House. A National Trust Garden and Property (April 2010) http://www.ascottestate.co.uk/

Asian Historical Architecture 'A Famosa Fortress' Asian Historical Architecture (March 2010) http://www.orientalarchitecture.com

Australian High Commission Malaysia "What are the MACC Scholarships?" Australian High Commission Malaysia (October 2009) http://www.malaysia.embassy.gov.au

Beswick, Jon "Comments: Diary from Africa" World Architecture News (April 2010) http://www.worldarchitecturenews.com

Bernad, Martina Millà "The Architecture of Colonial Presence" Emory University (April 2010) http://www.english.emory.edu/Bahri/Architecture.html

Cardoza, Elizabeth "Bok House a window into the world that was" New Straits Times 9 July 2006:22 
Chan, Chee Yoong Post-Merdeka Architecture Malaysia 1957-1987 (Kuala Lumpur: Pertubuhan Akitek Malaysia, 1987)

Chan, Debbie "So closely linked to birth of a nation" The Star Online (August 2006) http://thestar.com.my/news/story.asp?file=/2006/8/31/central/15267177\&sec=central

Chen, Voon Fee 'Architecture' The Encyclopaedia of Malaysia (Singapore: Archipelago Press, 1998)

Chin, W.Y "Towards a National Identity in Architecture" Majallah Akitek (March 1981) v.81, n.1, pp. 19-22.

Choong, Jonathan Siong Vui Multiculturalism : the roots of Malaysian Architecture and Identity (Wellington: Victoria University of Wellington, 2003)

City of Glendale California "Tudor Style" City of Glendale California (March 2010) http://www.ci.glendale.ca.us/planning/pdf_files/HistoricDistrictsDesignGuidelines/council\%20draft \%20HDDG/13_Tudor_Style.pdf

Colombo Plan's Secretariat "The Colombo Plan" The Colombo Plan's Secretariat (October 2009) http://www.colombo-plan.org/

Cooper, Diana "Loke Mansion" Heritage of Malaysia Trust (June 2007) http://www.badanwarisan.org.my/buletins/apr_june07a.pdf

Crouch, Dora P. and Johnson, June G. Traditions in Architecture (Oxford: Oxford University Press, 2001)

De Witt, Dennis "The Stadthuys of Malacca" Holland Focus (April 2010) http://www.hollandfocus.com

Downer, Alexander "Launch of Australia and the Colombo Plan 1949-1957" Australian Government Department of Foreign Affairs and Trades (October 2009) http://www.foreignminister.gov.au

Encyclopedia of Vernacular Architecture of the World ed. Oliver, Paul (Cambridge: Cambridge University Press, 1997)

Fels, Patricia T "Conserving the Shophouse City" The Penang Story-International Conference 2002 (April 2002) pp1-17

Heath, Kingston W. Vernacular Architecture and Regional Design: Cultural Process and Environmental Response (Oxford: Architectural Press, 2009)

Hijjas Kasturi Assocates Sdn "Philosophy" Hijjas Kasturi Assocates Sdn (October 2009) http://www.hijjaskasturi.com/ 
Ho, Kah Chun and Hasan, Ahmad Sanusi and Noordin, Norizal M. "An Influence of Colonial Architecture to Building Styles and Motifs in Colonial Cities in Malaysia" School of Housing, Building \& Planning (SEPTEMBER 2005) http://www.vintagemalaya.com

Houses for the $21^{\text {st }}$ Century ed. London, Geoffrey (Australia: Pesaro Publishing, 2003)

Ismail, Wan Hashimah Wan Houses in Malaysia. Fusion of the East and the West. (Malaysia: University Technology of Malaysia , 2005)

Kamal, Kamarul Syahril Bin "Heritage Cities of Malaysia: The Penang Chapter, Penang, Malaysia" Building Conservation (July 2008) http://buildingconservation.blogspot.com

Kamal, Kamarul Syahril Bin and Wahab, Lilawati Ab. "Adaptation Design of Traditional Malay House to Meet the Requirements of Comfort Living in Modern Houses" Mara University of Technology (October 2009) http://buildingconservation.blogspot.com/2007/03/adaptation-design-oftraditional-malay.html

Kent, Susan Domestic architecture and the use of space (Cambridge: Cambridge University Press, 1990)

King, Ross Kuala Lumpur and Putrajaya: negotiating urban space in Malaysia (Denmark: NIAS Press, 2008)

King, Anthony D. The Bungalow. The Production of a Global Culture (London: Oxford University Press, 1995)

Lai, Chee Kien “Shipley, an Architect Extraordinaire” New Sunday Times 27 July 2008:12

Lawley, Meridith and Perry, Chad "Thai and Malaysian students' perceptions of overseas study destinations: An Exploratory Study" Lawley90 (February 2010) www.http://smib.vuw.ac.nz:8081/www/ANZMAC1998/Cd_rom/Lawley90.pdf

Leong San Tong Khoo Kongsi "The tour" Khoo Kongsi Online (March 2010)

http://www.khookongsi.com.my/

Lim, Gaik Siang "Khoo Kongsi Clanhouse and Community: Transformation of Social and Spatial Relationships" The Penang Story-International Conference 2002 (April 2002) pp1-22

Lim, Jee Yuan The Malay House. Rediscovering Malaysia's Indigenous Shelter System (Malaysia: Institut Masyarakat, 1987)

Lim, William S.W and Tan, Hock Beng The New Asian Architecture: Vernacular Traditions and Contemporary Style (Singapore: Select Books Pte Ltd, 1998) 
Malaysian Australian Alumni Council "Colombo Plan Anniversary Book" Malaysian Australian Alumni Council (November 2009) http://www.emaac.org

Malaysia Builder "Carcosa Seri Negara" Malaysia Builder (March 2010) http://www.malaysiabuilder.com

McGillick, Paul Concrete Metal Glass: Hijas Kasturi Associates: Selected Works 1977-2007 (Kuala Lumpur: Editions Didier Millet Sdn Bhd, 2006)

Muzium Negara "History" Muzium Negara (March 2010) http://www.muziumnegara.gov.my

National Library of Malaysia "Sultan Abdul Samad Building" History of Malaysia (April 2005) http://sejarahmalaysia.pnm.my

NZ Islam Awareness "What are the Five Pillars of Islam?" NZ Islam Awareness (May 2010) http://www.islamawareness.co.nz/5pillars.php

Oakman, Daniel "Young Asians in our homes: Colombo Plan students and White Australia" Journal of Australian Studies | (1 January 2002) 72, pp. 89-98

Oliver, Paul Built to meet needs. Cultural Issues in Vernacular Architecture (Oxford: Elsevier Ltd, 2006)

Oliver, Paul Dwellings (London: Phaidon Press Limited, 2003)

Ong, Christopher "Swan and Maclaren" National Library of Singapore (February 2009) http://infopedia.nl.sg/

Powell, Robert The Asian House: Contemporary Houses of South East Asia (Singapore: Select Books Pte Ltd, 1993)

Rapoport, Amos "Vernacular architecture and the cultural determinants of form" Buildings and Society ed. King, Anthony D. (London: Routledge and Kegan Paul Ltd, 1980), pp. 283-302

Reed, Mike "Visiting Longhouses" My One Stop Sarawak (September 2009) http:// www.sarawak.com.my/

Royal Selangor Club "RSC Since 1884 the Humble Beginning" Royal Selangor Club (April 2010) http://www.rscweb.my/rsc2/

Salkow, Howard "Australian experience builds global perspective" Lumen The University of Adelaide Magazine (October 2009) http://www.adelaide.edu.au/

Saujana Hotels \& Resorts “Carcosa Seri Negara” Saujana Carcosa Seri Negara (March 2010) http://www.creativejin.net/Saujana/web/ 
Schneider-John, Christina Vernacularisation in Architecture (Wellington: Victoria University of Wellington,2004)

Tettoni, Luca Invernizzi and Ong, Edric Sarawak Style (Singapore: Times Editions, 2001)

The Colombo Plan for cooperative economic development in South and South East Asia 1951 - 2001 ed. Sauer, Geoffrey (Australia: The Malaysia-Australia Foundation, 2001)

Tour UK "Ascott House" Ascott House (March 2010) http://www.touruk.co.uk Tourism Malaysia “About Malaysia” Tourism Malaysia (April 2010) http://www.tourism.gov.my/

Tye, Timothy "Portuguese Settlement, Kampung Hilir, Malacca" Asia Explorers (April 2010) http://www.asiaexplorers.com/malaysia/portuguese_settlement.htm

U.S. Embassy Malaysia and Badan Warisan (Heritage Trust) Malaysia "Malacca" Ambassadors Fund for Cultural Preservation (April 2010) http://usembassymalaysia.org.my

Underwood, David Oscar Niemeyer and the Architecture of Brazil (New York: Rizzoli International Publications, Inc, 1994)

University of Melbourne "Award Winning Architect to be Awarded Honorary Doctorate by the University of Melbourne" University of Melbourne (October 2009) http://uninews.unimelb.edu.au

University of Technology "About the Faculty" Faculty of Built Environment (April 2010) uhttp://web.utm.my/fab/

Upton, Dell “'Authentic' Anxieties" Consuming Tradition, Manufacturing Heritage ed. Alsayyad, Nezar (London: Routledge, 2001) pp. 298-306

Vaz, Justine and Tan, Amy Endeavours of excellence: over 50 years of Australian scholarships (Australia: Australian Education International, 2008)

Vernacular Architecture in the Twenty-First Century: Theory, education and practice ed. Asquith. L and Vellinga.M (Oxon: Taylor and Francis, 2006)

Vernacular Modernism ed. B Huppauf and M. Umbach ( Stanford: Stanford University Press, 2005)

Waller, Martin and Bradbury, Dominic Fusion Interiors (London: Pavilion Books Limited, 2000)

Waterson, Roxana The Architecture of South-East Asia through Travellers' Eyes (New York: Oxford University Press, 1998)

Waterson, Roxana The Living House: An Anthropology of Architecture in South-East Asia (Oxford: Oxford University Press Pte Ltd, 1990) 
Widodo "Modern Indonesian Architecture" The Past in the Present: Architecture in Indonesia ed. Nas, Peter J.M. (Rotterdam: NAi Publishers, 2006) pp. 17-24

Winzeler, Robert L. The Architecture of Life and Death in Borneo (United States of America: University of Hawai'i Press, 2004)

Yeang, Ken The Architecture of Malaysia (Amsterdam: The Pepin Press, 1992)

Yeang, Ken Tropical Urban Regionalism (Singapore: Concept Media Pte Ltd, 1987) 


\section{List of Illustrations and Credit}

\section{Introduction}

0.1 Map of Malaysia

Yeang, Ken The Architecture of Malaysia (Amsterdam: The Pepin Press, 1992)

\section{Chapter 1: Malaysian Vernacular Architecture Part I (pre-16 ${ }^{\text {th }}$ century)}

1.1 The traditional Malay house

Malaysia Truly Asia "History" Malaysia Truly Asia (April 2010) http://touringmalaysia.wordpress.com

1.2 The roof style of the Minangkabau-style house in Negeri Sembilan and the Sumatran house in Indonesia

Chen, Voon Fee "Architecture" The Encyclopaedia of Malaysia (Singapore: Archipelago Press, 1998)

1.3 The headman's house

Chen, Voon Fee "Architecture" The Encyclopaedia of Malaysia (Singapore: Archipelago Press, 1998)

1.4 Interior Spaces in the Malay House

Ismail, Wan Hashimah Wan Houses in Malaysia. Fusion of the East and the West. (Malaysia: University Technology of Malaysia , 2005)

1.5 Common Addition sequences of the traditional Malay house

Lim, Jee Yuan The Malay House. Rediscovering Malaysia's Indigenous Shelter System (Malaysia: Institut Masyarakat, 1987)

1.6 Front elevation, section and plan of the Malay house

Tettoni, Luca Invernizzi and Ong, Edric Sarawak Style (Singapore: Times Editions, 2001)

1.7 Malay house in Merlimau, Melaka

Zui, Yan Hong "Merlimau Village Headman House" Sweet Memories of ZuiYanHong (July 2009) http://www.zuiyanhong.com/

1.8 Various Types of Malay house

Lim, Jee Yuan The Malay House. Rediscovering Malaysia's Indigenous Shelter System (Malaysia: Institut Masyarakat, 1987)

\section{Chapter 2: Malaysian Vernacular Architecture Part II (pre-16 ${ }^{\text {th }}$ century)}

2.1 Distribution of longhouse communities in Sarawak

Chen, Voon Fee "Architecture" The Encyclopaedia of Malaysia (Singapore: Archipelago Press, 1998)

2.2 An Uma, communal house of the Mentawai, Indonesia

Wikipedia "Long House" Wikipedia the Free Encyclopaedia (March 2010) http://en.wikipedia.org/wiki/Long_house

2.3 An Mnong longhouse in the central highlands of Vietnam 
Wikipedia "Long House" Wikipedia the Free Encyclopaedia (March 2010) http://en.wikipedia.org/wiki/Long_house

2.4 Orientation of the longhouse

The Iban Longhouse "The Iban Longhouse" Iban Cultural Heritage (August 2009) http://gnmawar.wordpress.com

2.5 Log steps of Iban longhouse, Sarawak

Staffordshire Learning Net Geography "Nanga Sumpa Lodge and Longhouse and the Iban people" Geography (March 2010)

http://www.sln.org.uk/geography/nanga_sumpa_and_iban_people.htm

2.6 Log steps of Iban longhouse, Sarawak

Index "Sarawak Stairs" Index (April 2010) www.hps.com/ tpg/singapore/graphics/

2.7 The Iban longhouse, Sarawak

Colin Jong "Iban House" Colin Jong (June 2009) http://colinjong.com/2009/06/19/sarawakcultural-village-6-ibans-house/

2.8 Elevations and floor plans of the Iban longhouse

Tettoni, Luca Invernizzi and Ong, Edric Sarawak Style (Singapore: Times Editions, 2001)

2.9 The Melanau tall house, Sarawak

Tye, Timothy "Melanau Tall House" Asia Explorers (August 2009)

http://www.asiaexplorers.com

2.10 Elevations, Sections and Floor Plans of the Melanau Tall House

Tettoni, Luca Invernizzi and Ong, Edric Sarawak Style (Singapore: Times Editions, 2001)

2.11 The Orang Ulu longhouse

Tye, Timothy "The Orang Ulu longhouse"Asia Explorers (August 2009) http://www.asiaexplorers.com

2.12 The Orang Ulu "tree of life" mural

Ashwin Nanjappa "Mural" Attempts of a novice at photography (September 2009) http://chaayaa.wordpress.com/2009/09/10/mural/

2.13 Elevations, sections and floor plans of the Orang Ulu longhouse

Tettoni, Luca Invernizzi and Ong, Edric Sarawak Style (Singapore: Times Editions, 2001)

2.14 The Bidayuh longhouse, Sarawak

Alfred Molon "Bidayuh Longhouse" Photo Galleries (March 2010) http://www.molon.de/

2.15 Elevation, plan and section of the Bidayuh Longhouse and elevation and floor plan of the head house)

Tettoni, Luca Invernizzi and Ong, Edric Sarawak Style (Singapore: Times Editions, 2001)

2.16 The baruk or men's head house

Alfred Molon "Bidayuh Headhouse" Photo Galleries (March 2010) http://www.molon.de/

\section{Chapter 3: Foreign Influenced Architecture Part 1 (1511-1957)}

3.1 A row of early timber shophouses in Penang

Chen, Voon Fee "Architecture" The Encyclopaedia of Malaysia (Singapore: Archipelago Press, 1998)

3.2 A row of Chinese shophouses 
Chen, Voon Fee "Architecture" The Encyclopaedia of Malaysia (Singapore: Archipelago Press, 1998)

3.3 The transition of shophouse façade design

Chen, Voon Fee "Architecture" The Encyclopaedia of Malaysia (Singapore: Archipelago Press, 1998)

3.4 Plan of Melakan townhouse

Chen, Voon Fee "Architecture" The Encyclopaedia of Malaysia (Singapore: Archipelago Press, 1998)

3.5 A Melakan townhouse

Chen, Voon Fee "Architecture" The Encyclopaedia of Malaysia (Singapore: Archipelago Press, 1998)

3.6 Side view showing the length of a typical Melakan townhouse

Chen, Voon Fee "Architecture" The Encyclopaedia of Malaysia (Singapore: Archipelago Press, 1998)

3.7 The Cheng Hoon Teng temple, Melaka

Tye, Timothy "The Cheng Hoon Teng temple" Asia Explorers (July 2005)

http://www.asiaexplorers.com

3.8 The Khoo Kongsi building in Penang

Ferreroroche's Weblog "Penang with JetStar" Ferreroroche's Weblog (July 2009)

http://ferreroroche.wordpress.com/

3.9 The Khoo Kongsi complex in Penang

Chen, Voon Fee "Architecture" The Encyclopaedia of Malaysia (Singapore: Archipelago Press, 1998)

3.10 The administrative building of the Khoo Kongsi, Penang

Leong San Tong Khoo Kongsi "The Administrative Building" Khoo Kongsi Online (March 2010) http://www.khookongsi.com.my/

3.11 The A Famosa fortress, Melaka

Vacations Malaysia "Ten simple reasons why you have to visit Malaysia" Vacations Malaysia

(April 2010) http://www.asiaexplorers.com

3.12 House in a Portuguese settlement in Melaka

Tye, Timothy "Portuguese Settlement" Asia Explorers (April 2010)

http://www.asiaexplorers.com

3.13 Catholic portrait on wall of house in a Portuguese settlement in Melaka

Tye, Timothy "Portuguese Settlement" Asia Explorers (April 2010)

http://www.asiaexplorers.com

3.14 The Stadthuys, Melaka

Tye, Timothy "Stadthuys" Asia Explorers (April 2010) http://www.asiaexplorers.com

3.15 The Christ Church, Melaka

Tye, Timothy "Christ Church" Asia Explorers (April 2010) http://www.asiaexplorers.com

3.16 The earlier townhouses in Hereen Street, Melaka

Ho, Kah Chun and Hasan, Ahmad Sanusi and Noordin, Norizal M. "An Influence of Colonial Architecture to Building Styles and Motifs in Colonial Cities in Malaysia" School of Housing, Building \& Planning (September 2005) http://www.vintagemalaya.com

3.17 The newer townhouses in Hereen Street, Melaka 
Ho, Kah Chun and Hasan, Ahmad Sanusi and Noordin, Norizal M. "An Influence of Colonial Architecture to Building Styles and Motifs in Colonial Cities in Malaysia" School of Housing, Building \& Planning (September 2005) http://www.vintagemalaya.com

3.18 Elevation of an old house on Heeren Street, Melaka

Ho, Kah Chun and Hasan, Ahmad Sanusi and Noordin, Norizal M. "An Influence of Colonial Architecture to Building Styles and Motifs in Colonial Cities in Malaysia" School of Housing, Building \& Planning (September 2005) http://www.vintagemalaya.com

3.19 Elevation of an old house on Heeren Street, Melaka

Ho, Kah Chun and Hasan, Ahmad Sanusi and Noordin, Norizal M. "An Influence of Colonial Architecture to Building Styles and Motifs in Colonial Cities in Malaysia" School of Housing, Building \& Planning (September 2005) http://www.vintagemalaya.com

3.20 The Sultan Abdul Samad building, Kuala Lumpur

Tye, Timothy "Sultan Abdul Samad building" Asia Explorers (April 2010)

http://www.asiaexplorers.com

3.21 The Ipoh Railway Station, Perak

Tye, Timothy “Ipoh Railway Station“ Asia Explorers (April 2010) http://www.asiaexplorers.com

3.22 Common arrangement of Iban longhouses on a main river and side streams

Winzeler, Robert $L$ The Architecture of Life and Death in Borneo (United States of America: University of Hawai'i Press, 2004)

3.23 The KTMB Railway map

Malayan Railway Fansite "Railway Map" Malayan Railway Fansite (March 2010) http://www.keretapi.com/railwaymap.html

3.24 The plan of a Kenyah longhouse

Winzeler, Robert $L$ The Architecture of Life and Death in Borneo (United States of America: University of Hawai'i Press, 2004)

3.25 The older portion and latest addition to the Royal Selangor Club building, Kuala Lumpur Wikipedia "Royal Selangor Club" Wikipedia the Free Encyclopaedia (March 2010) http://en.wikipedia.org/wiki/Royal_Selangor_Club

3.26 The earlier Royal Selangor Club building German, Ralph L. Handbook to British Malaya (London: R. L. German, 1927)

3.27 The Ascott House in Buckinghamshire, England

Wikipedia "Ascott House" Wikipedia the Free Encyclopaedia (March 2010) http://en.wikipedia.org/wiki/Ascott_House

3.28 Plaque shown at the entrance of the Royal Selangor Club bar

Tour Malaysia "KL Heritage Trail: Royal Selangor Club" Tour Malaysia (March 2010) http://www.tourmalaysia.com/

3.29 St. Mary's Cathedral

Wikipedia "St. Mary's Cathedral, Kuala Lumpur" Wikipedia the Free Encyclopaedia (March 2010) http://en.wikipedia.org/wiki/St._Mary's_Cathedral,_Kuala_Lumpur

3.30 St. Andrew's Presbyterian Church

St. Andrew's Presbyterian Church "St. Andrew's Presbyterian Church" St. Andrew's Presbyterian Church http://standrewschurch.org.my/about-us/history/1924-1960-times-oftesting

3.31 The Carcosa Seri Negara mansion, Kuala Lumpur 
Asian Trails "Carcosa Seri Negara" Asian Trails (April 2010) http://www.asiantrails.info/index

3.32 The front porch of Carcosa Seri Negara

Ariff "Carcosa Seri Negara" Signature (March 2009)

http://ariff2001.blogspot.com/2009/03/carcosa-seri-negara-carcosa-seri-negara.html

3.33 The verandah of the Carcosa Seri Negara mansion

Bose, Romen "Grand past but uncertain future for Carcosa" My Sinchew (December 2009) http://ap.mysinchew.com/node/33274

3.34 The drawing room of the Carcosa Seri Negara mansion

Ariff "Carcosa Seri Negara" Signature (March 2009) http://ariff2001.blogspot.com/200 9/03/carcosa-seri-negara-carcosa-seri-negara.html

3.35 Heath's 'Dynamics that shape vernacular form' model

Heath, Kingston W. Vernacular Architecture and Regional Design: Cultural Process and Environmental Response (Oxford: Architectural Press, 2009)

\section{Chapter 4: Foreign Influenced Architecture Part II (1511-1957)}

\subsection{Bungalow in India}

King, Anthony D. The Bungalow. The Production of a Global Culture (London: Oxford University Press, 1995)

4.2 The Suffolk House, Penang

Tye, Timothy "Suffolk House "Asia Explorers (April 2010) http://www.asiaexplorers.com

4.3 Syed Alatas mansion, Penang

Tye, Timothy "Penang Islamic Museum (Syed Alatas Mansion)" Penang Travel Tips (April 2010) http://www.penangtraveltips.com

4.4 Interior view of the Syed Alatas mansion, Penang

Tye, Timothy "Penang Islamic Museum (Syed Alatas Mansion)" Penang Travel Tips (April 2010) http://www.penangtraveltips.com

4.5 The front elevation of the Bok House, Kuala Lumpur

Abdullah, Azrul K. "Bok House 1929"Azrul K. Abdullah Architectural Photographer (2001)

http://www.mir.com.my/rb/photography/portfolio/azrul/html/bokstart.html

4.6 The dining room of the Bok House, Kuala Lumpur

Abdullah, Azrul K. "Bok House 1929“Azrul K. Abdullah Architectural Photographer (2001)

http://www.mir.com.my/rb/photography/portfolio/azrul/html/bokstart.html

4.7 The foyer of the Bok House, Kuala Lumpur

Abdullah, Azrul K. "Bok House 1929" Azrul K. Abdullah Architectural Photographer (2001)

http://www.mir.com.my/rb/photography/portfolio/azrul/html/bokstart.html

4.8 The Loke Yew mansion, Kuala Lumpur

Ho, Kah Chun and Hasan, Ahmad Sanusi and Noordin, Norizal M. "An Influence of Colonial Architecture to Building Styles and Motifs in Colonial Cities in Malaysia" School of Housing, Building \& Planning (September 2005) http://www.vintagemalaya.com

\section{Chapter 5: Contemporary Malaysian Architecture (1957-present)}

5.1 Syariah Courthouse (1986) 
McGillick, Paul Concrete Metal Glass: Hijias Kasturi Associates: Selected Works 1977-2007 (Kuala Lumpur: Editions Didier Millet Sdn Bhd, 2006)

5.2 Kuwait Embassy (1988)

McGillick, Paul Concrete Metal Glass: Hijias Kasturi Associates: Selected Works 1977-2007 (Kuala Lumpur: Editions Didier Millet Sdn Bhd, 2006)

5.3 The Marco Polo Hotel, Tawau

ETawau "Belmont Marco Polo Hotel, Tawau" ETawau (May 2010) http://www.etawau.com

5.4 The Borneo Resthouse Hotel, Kota Kinabalu

Ahyer Malaysia "Borneo Resthouse Hotel" Frazer, Kota Kinabalu (May 2010)

http://www.ahyer.com/kota-kinabalu-hotel-for-sale-11393-5

5.5 The Metropolitan Cathedral (1959) in Brasilia

Underwood, David Oscar Niemeyer and the Architecture of Brazil (New York: Rizzoli International Publications, Inc, 1994)

5.6 Concrete fins and screens

Chen, Voon Fee "Architecture" The Encyclopaedia of Malaysia (Singapore: Archipelago Press, 1998)

5.7 Horizontal and vertical louvers

Chen, Voon Fee "Architecture" The Encyclopaedia of Malaysia (Singapore: Archipelago Press, 1998)

5.8 Metal sunscreen cladding

Chen, Voon Fee "Architecture" The Encyclopaedia of Malaysia (Singapore: Archipelago Press, 1998)

5.9 The Parliament House, Kuala Lumpur

Tye, Timothy "Parliament House" Asia Explorers (April 2010) http://www.asiaexplorers.com

5.10 The lobby of the Parliament House

Ngan, Teng Yuen "The Malaysia Houses of Parliament Building" Mirage Studio 7 (July 2008) http://blog.miragestudio7.com/

5.11 The lobby of the Parliament House

Ngan, Teng Yuen "The Malaysia Houses of Parliament Building" Mirage Studio 7 (July 2008) http://blog.miragestudio7.com/

5.12 The lobby of the Parliament House

Ngan, Teng Yuen "The Malaysia Houses of Parliament Building" Mirage Studio 7 (July 2008) http://blog.miragestudio7.com/

5.13 The triangular concrete pinnacles of the Parliament House, Kuala Lumpur

WrldVoyagr "Malaysia Parliament" Flickr (June 2007)

http://www.flickr.com/photos/wrldvoyagr/3604951482/

5.14 A Malay house in Melaka

Yeang, Ken The Architecture of Malaysia (Amsterdam: The Pepin Press, 1992)

5.15 The United States Air Force Academy chapel in Colorado Air Force Academy, Colorado "Hazardous Materials and Waste Management Division" Air Force Academy http://www.cdphe.state.co.us/hm/academy.htm

5.16 National Museum 
Tye, Timothy "Muzium Negara, Kuala Lumpur" Asia Explorers (April 2010) http://www.asiaexplorers.com

5.17 The Balai Besar (Great Council Hall)

Tye, Timothy "Balai Besar, Alor Setar" Asia Explorers (April 2010) http://www.asiaexplorers.com

5.18 National Museum, Kuala Lumpur

Wikipedia "National Museum (Malaysia)" Wikipedia the Free Encyclopaedia (March 2010) http://en.wikipedia.org/wiki/File:National_Museum_KL_2008_interior_pano.jpg

5.19 Natural History Museum, London

The Victorian Web "Main staircase, Natural History Museum by Alfred Waterhouse" The Victorian Web (March 2010) http://www.victorianweb.org/art/architecture/nhm/10.html

5.20 The Bank Negara (National Bank) (1983)

McGillick, Paul Concrete Metal Glass: Hijjas Kasturi Associates: Selected Works 1977-2007 (Kuala Lumpur: Editions Didier Millet Sdn Bhd, 2006)

5.21 Detail of the external pillar

McGillick, Paul Concrete Metal Glass: Hijjas Kasturi Associates: Selected Works 1977-2007 (Kuala Lumpur: Editions Didier Millet Sdn Bhd, 2006)

5.22 Lembaga Tabung Haji (Pilgrim's Fund) (1984)

Wt Consultants, Inc "Home" Wt Consultants, Inc (May 2010) http://wtconsultants.net/

5.23 Plan and section of the Lembaga Tabung Haji Building (Pilgrim's Fund)

McGillick, Paul Concrete Metal Glass: Hijjas Kasturi Associates: Selected Works 1977-2007 (Kuala Lumpur: Editions Didier Millet Sdn Bhd, 2006)

5.24 Ribbed roof detail at the main entrance

McGillick, Paul Concrete Metal Glass: Hijjas Kasturi Associates: Selected Works 1977-2007 (Kuala Lumpur: Editions Didier Millet Sdn Bhd, 2006)

5.25 Moulded ceiling above the entrance

McGillick, Paul Concrete Metal Glass: Hijjas Kasturi Associates: Selected Works 1977-2007 (Kuala Lumpur: Editions Didier Millet Sdn Bhd, 2006) 


\section{Glossary}

Anjung: Covered entrance porch where guests are greeted and male guests often entertained and where family members can relax.

Attap(or atap): Lightweight yet insulating roof thatch, often made from nipah, rumbia or bertam leaves

Baruk: Bidayuh men's house or head house

Batik: traditional hand-dyed fabric

Belian: Eusideroxylon zwagerii (La.), ironwood; a highly durable timber species indigenous to Sabah and Sarawak

Bertam: Eugeissona tristis(La.), a local palm species whose leaves are used for roof thatch

Bilik- Room, apartment in a longhouse

Bumbung: Roof

Bumbung lima: "Five ridged roof" hipped roof comprising two sloping roofs

Bumbung Panjang: "Long ridge roof, gable roof comprising two sloping roofs"

Bumbung Perak: Gambrelroof, or a hipped roof with gable-like ends

Bumbung Meru 2-Tingkat:

Cengal: Neobalanocarpus heimii (La.), a very durable hardwood

Dapur: Kitchen

Jelutong: Dyera costulata(La.), a non- durable timber species

Kampung (or kampong): Village

Kolong: the underside of a Malay house raised on stilts

Kongsi: Chinese clan house, literally translates as 'to share' or 'a shared company'

Loceng: Attic

Meranti: Shorea spp.(La.), moderately durable timber of the genus

Merbau: Intsia palembanica(La.), a species of durable timber

Nipah: Nypa fruticans(La.), a variety of creeping palm whose fronds are used for roof thatch

Pelantar: Raised platform at the rear of a Malay house used for washing and drying

Penai: a bathing place by the river 
Penghulu: leader of the Malay village, village headman

Resak: Vatica spp.(La.), a species of hard and durable timber

Rowhouse:

Ruai: Gallery in a longhouse

Rumah Ibu: Core area and the most private part of a Malay house in which occupants pray, sleep and perform household chores such as sewing and ironing

Rumah Tinggi: literally, tall house

Rumbia: Metroxylon rumphii(La.), a species of palm whose leaves are used for roof thatch

Sadau: the loft of the longhouse

Selang: Covered passageway linking the main part of a Malay house to the kitchen

Serambi Gantung: 'Hanging' veranda in front of a house

Serambi Samanaik: Closed verandah

Shophouse: Two-storey urban house with a ground floor shop open to the road and living quarters upstairs

Stadthuys: an old Dutch spelling, literally meaning "town hall

Tanju: Open deck in a longhouse

Tiang Seri: Central post

Tuai Rumah: longhouse chief 